\title{
THE PINELANDS DEVELOPMENT CREDIT PROGRAM
}

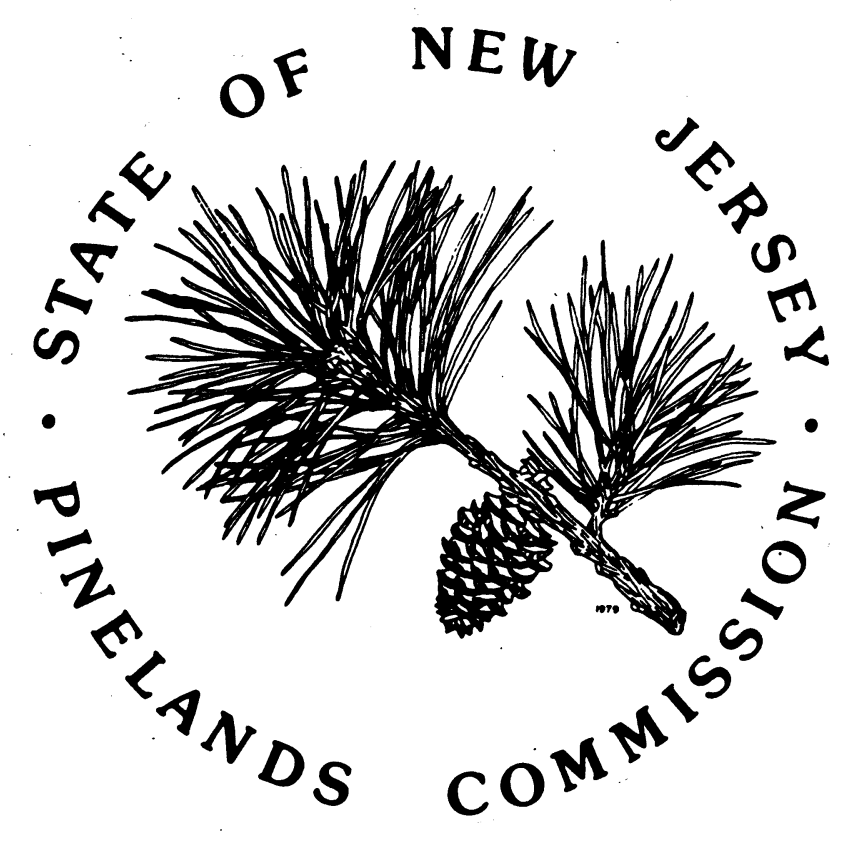

October 1988

REPORT TO THE PINELANDS COMMISSION 
October 1988

REPORT TO THE PINELANDS COMMISSION

The Pinelands Commission

P.O. Box 7

New Lisbon, New Jersey 08064

(609) 894-9342 
I. INTRODUCTION

II. THE RESEARCH PROGRAM . . . . . . . . . . . . . 3

A. ROUND TABLE . . . . . . . . . . . . . . . 3

B. Data COllection And analysis . . . . . . . . 3

B.1) Letters of Interpretation.

B.2) Information on PDC Sales and Purchases.

B.3) Review of experience with other TDR programs.

B.4) Status Report on Projects Using PDCs

B.5) Review of Approved Projects With 10 or More Units

B.6) Review of RGA land

B.7) Zoning Analysis: Density Range of Bonus Units

B.8) Zoning Analysis: Bulk Standards

B.9) Market Study

B.10) Building Permit and Population Data.

B.11) Economic Analysis

III. DATA AND FINDINGS . . . . . . . . . . . . . . . 11

A. PDC SALES AND PURCHASES . . . . . . . . . . . 11

B. LETTERS OF INTERPRETATION . . . . . . . . . 12

C. STATUS REPORTS ON PROJECTS USING PDCS . . . . . . 14

D. DENSITY OF APPROVED PROJECTS . . . . . . . . . 15

E. USE OF PDCS IN APPROVED PROJECTS . . . . . . . . . 17

F. PERMITTED AND ACTUAL UNITS IN APPROVED PROJECTS • • 19

G. BUILDING PERMIT SUMMARIES . . . . . . . . . 21

H. SALES DATA FOR FOUR SELECTED MUNICIPALITIES • • • 23

H.1) Sales by Municipality and Weighting Factors

H. 2) Sales by Pinelands and Non-Pinelands Location

H. 3) Housing Type

H.4): Gross Density by Municipality

H.5) Gross Density by Pinelands and CAFRA Location

H.6) Floor Area

I. ECONOMIC ANALYSIS . . . . . . . . . . . 30

J. DENSITY INCREASE OBTAINED THROUGH PDC USE . . . . 34

K. DENSITY RANGES WHERE PDC BONUSES MAY BE EXERCISED • 35

L. ZONING STANDARDS ANALYSIS . . . . . . . . . 42 
M. WETLANDS AND BUFFERS IN APPROVED PROJECTS . • • • . 45

N. POPULATION AND HOUSEHOLD PROJECTIONS . . . . . . . 48

O. LESSONS FROM OTHER TDR PROGRAMS . . . . . . . . . . 48

o.1) Montgomery County, Maryland

$0.2)$ Calvert County, Maryland

$0.3)$ Collier County, Florida

$0.4)$ San Luis Obispo, California

$0.5)$ Santa Monica Mountains, California

$0.5)$ Buckingham Township, Pennsylvania

P. USES FORGONE ON SALE OF PDCS . . . . . . . . . . . 51

Q. PINELANDS INFRASTRUCTURE TRUST SEWER PROJECTS • • . 51

IV. CONCLUSIONS . . . . . . . . . . . . . . 53

A. STATUS OF THE PDC PROGRAM . . . . . . . . . . . 53

B. SUITABILITY OF REGIONAL GROWTH AREAS FOR DEVELOPMENT 54

C. ECONOMIC AND DENSITY CONSIDERATIONS . . . . . . . 55

D. ZONING STANDARDS AND ACHIEVABLE DENSITY • • • • • • 56

E. ENVIRONMENTAL STANDARDS AS THEY RELATE TO DEVELOPMENT POTENTIAL . • . . . . . . . . . . . 58

V. RECOMMENDATIONS • . . . . . . . . . . . . . . . . 59

A. ACTIONS INVOLVING VIRTUALLY NO STRUCTURAL CHANGE IN THE PDC PROGRAM OR THE CMP . . . . . . . . . . 59

A.1) PDC Advocacy Staff

A.2) Re-examination of Municipal Zoning

A.3) New Endorsements for Pinelands Infrastructure Trust Sewer Projects

A.4) Simplify CMP Re: Variance and Retained Right to Build

A.5) Priority Review for PDC Projects

B. ACTIONS WHICH WOULD HAVE LITTLE STRUCTURAL EFFECT ON-THE PDC PROGRAM OR CMP . . . . . . . . . . . . 62

B.1) Simplified Allocation and Redemption Formula

B.2) Limit PDC Use at Higher Densities

B.3) Revised Municipal Reserve Conversion

C. ACTIONS INVOLVING MORE SUBSTANTIAL CHANGES TO THE PDC

PROGRAM AND THE CMP . . . . . . . . . . . . . . . . 67

C.1) Guaranteed Residential PDC Use Option

C.2) Commercial and Industrial Use Option

D. SUMMARY • . . . . . . . . . . . . . . . . . 70 


\section{INTRODUCTION}

The Pinelands Comprehensive Management Plan (CMP) includes a transfer of development rights program using what are defined in the CMP as Pinelands Development Credits (PDCs). The program is intended to more equitably distribute the burden of restrictive regulation and the benefits of growth encouraging zoning and infrastructure, and to achieve more permanent protection of certain ecologically unique and valuable resources. Owners of restricted land may sell development credits, which may be used to increase the amount of residential development permitted in Regional Growth Areas. When a PDC is sold, a conservation easement restricting future development of the parcel from which the PDC was transferred must be recorded.

In the years since the adoption of the CMP the PDC program has gradually taken hold. Several residential developments have been constructed with PDC bonus units, and other PDC projects have been approved but not yet constructed. Burlington County has established a "bank" that has purchased and sold some credits, a handful of credits have transferred privately, a state PDC bank has recently become operational, and several large projects have been conceptualized in a way that would use PDCs. However, the number of projects using PDCs has not been large, and the total number of credits actually redeemed has been small (at least 8 credits are known to have been redeemed).

Over time, the PDC program has taken on much greater significance than initially envisioned when the CMP was adopted. The Pinelands Commission determined that the program should be evaluated to determine what its strengths and weaknesses are and to identify various measures which could be used to further strengthen it. This report represents the second part of a two pronged evaluation.

Previous work performed by consultant Karl Kehde reported on interviews with key actors in the program, including landowners, developers and municipal officials. That report described the level of awareness and understanding of those persons, and addressed a-number of related psychological issues.

Operational features of the program are the focus of this second phase. This report complements the previous work by focusing on empirical factors, including the nature of development approved in the Pinelands, the nature of housing sold in selected Pinelands municipalities, the economic value of a PDC, and certain particulars of zoning. A wide range of policy options is listed and discussed and a number of recommendations are presented in a final chapter. 
A number of favored theories have been proposed by critics and observers of the program. One of the prime hypotheses has been that the base densities in the program are too high and few developers wish to build at higher densities than those permitted without using PDCs. This may be true in some cases; certainly there are examples of developments that do not even reach the base density available. Another hypothesis is that Regional Growth Areas do not really offer prime development opportunities. Again, in some cases this is true, for there are areas which do not have sewer service, and may not for some time; on the other hand, there are other areas which either have sewer now or will soon.

A third hypothesis is that there is nothing wrong with the program; rather it is just a matter of giving it some promotion and giving it time to gain momentum. A related theory is that in the future land for development will become more scarce and the PDC density bonuses will become much more attractive. These theories certainly overlook the desire for the PDC program to function in the present rather than as a hope for the future. They may also overlook the large amount of land that could be developed at relatively low densitiés, perhaps, in a sense, "prematurely."

A number of recommendations are easy to make because they are unambiguously supported by data collected during the evaluation. Others are easy because they are clarifications of or refinements to existing policy. The most important recommendations, unfortunately, are not forced upon us by clear results in data collection or analysis. Housing market sales data do not show that home buyers shun the product that builders could offer at PDC bonus densities. The economic analysis does not indicate that the PDC is worth dramatically less when redeemed at higher densities. Both of these factors argue against a need to lower base densities. On the other hand, a look at residential developments approved in the Pinelands shows that densities in the Pinelands are lower than densities a few miles away outside of the Pinelands. As a consequence, certain key recommendations must be considered in the light of seemingly contradictory evidence. 


\section{T THE RESEARCH PROGRAM}

\section{A. ROUND TABLE}

Six knowledgeable professionals were invited to participate in a one day round table workshop to discuss the proposed scope of work for the research program. The purpose of the workshop was to discuss the practicality of the research planned, and the relationship of the research conceptually to the problem of identifying possible changes in policy for the Pinelands Development Credit Program. Five of the six were able to attend the workshop, review the proposed scope of work, and provide suggestions for conducting the research. The overall effect of the round table workshop was to ensure that the research program covered, in so far as time and resources permitted, the appropriate subject matter.

\section{B. DATA COLLECTION AND ANALYSIS}

Data collection and analysis focused on 11 different topical matters. These are summarized as follows:

\section{B.1) Letters of Interpretation.}

In as much as a Letter of Interpretation must be obtained before a PDC may actually be sold, Letters of Interpretation provide an indication of landowner interest in selling PDCs.

Pinelands Commission Staff keeps Letters of Interpretation on file, and also maintains a separate list of all Letters of Interpretation that allocate PDCs. The list was tabulated by year and by number of credits per Letter of Interpretation. The tabulation by number of credits provided an indication of whether the majority of Letters of Interpretation have been issued to owners of undersized lots, or whether a significant fraction of the Letters-were issued to owners of larger parcels of land. The tabulation-by year may provide an indication of the trend in landowner Interest in selling PDCs.

\section{B.2) Information on PDC Sales and Purchases.}

Available information on actual PDC transactions was collected and analyzed to determine what trends may exist in PDC sales and purchases. This information came from two sources. 
A list of transactions by the Burlington County Farmland Easement and Pinelands Development Credit Bank was requested. Burlington County's PDC purchases were tabulated by year, by municipality, and by management area. Burlington County's resales of PDCs to developers were also tabulated by year.

In addition, Pinelands Commission Development Review files were consulted to determine the number of PDCs involved in private transactions.

\section{B.3) Review of experience with other TDR programs.}

While it was known at the outset that there are few extremely successful transferable development rights programs, it was viewed as important to review other existing programs to determine what operational features were in use that might be of value for the Pinelands, and what program features or implementation strategies were viewed by participants as instrumental in the success or failure of the programs. A collection of written material was generated for a few key programs, and a series of telephone interviews was conducted to obtain information.

\section{B.4) Status Report on Projects Using PDCs}

From time to time since 1984, Commission staff has produced a report summarizing the status of development projects that would make use of PDCs. As part of that report, the total number of projects and the number of PDCs for each of 4 possible statuses were presented. The statuses are "Built", "Approved", "Active", and "Uncertain."

"Built" applies to projects that have been completely built;

"Approved" means having municipal approval which has been upheld by the Pinelands Commission, though some approved projects are under construction; "Active" means that a formal application has been received and is being actively pursued; "Uncertain" includes all other projects, whether a formal application has been received but has not been pursued for some time, or where a project has been the subject of conceptual pre-application conferences but has not been formally presented.

One report a year for 1984 through 1987, plus two reports for 1988 were tabulated to form a time series to indicate the trend in projects. 


\section{B.5) Review of Approved Projects With 10 or More Units}

A review of residential projects in Pinelands Regional Growth Areas was conducted to determine what prevailing development densities have been, what effect the presence of wetlands and wetland buffers may have had, how many PDC redemption opportunities have been used and how many PDC redemption opportunities have been bypassed. This analysis provides both an indication of whether Regional Growth Area land is being preempted by non PDC development, and an indication of the nature of the housing product that developers are offering housing buyers.

The Commission's computerized development review tracking system contains certain information on projects proposed, approved, and built in the Pinelands. The tracking system became operational in June of 1985. The system contains information on projects that have been acted on since that time. In addition, information on projects acted on during 1985 has been entered, as well as a fraction of projects from 1984 and earlier.

A list of approved projects located in Regional Growth Areas and including 10 or more dwelling units was extracted from a computer report generated in early May. Detailed analysis was conducted of each of the files identified from that list. Among the information collected was the total site area, the acres of wetland, the width of wetlands buffer, the acreage of wetland buffer, the acreage of upland not within the buffer, the number of units, the number of PDC bonus units, the municipal zone, form of sewage disposal, type of units, and the number and size of land parcels assembled.

A second computer report was generated in August for the purpose of reviewing the density of approved projects. This second report contained more projects than the May report because additional project information had been entered into the system, as a result of approvals granted since May, and ongoing entry of backlog information from 1984 and earlier. Detailed analysis of wetlands and zoning issues was not possible for the added projects on-the second report.

\section{B.6) Review of RGA land}

It has been noted by many analysts that a transferable development right program needs to have a viable receiving area in which rights can be utilized. With respect to the Pinelands Regional Growth Areas, there were three questions raised. One was whether there was an excessive amount of wetland and wetland buffer area. A second question was how much developable area was sewered. A third question raised was whether the tenure pattern 
of land parcels posed an obstacle to land assemblage for development.

A statistical sampling of land parcels was considered and rejected. One of the reasons for rejection was the recognition that the sampling and analysis work would be extremely time consuming, and the resulting data set would not permit discrimination to be made between the RGAs in various municipalities. A second factor was the urging of the round table participants that preparation of a set of overlay maps would enable easy intuitive interpretation and recognition of areas that were constrained by wetlands or fragmented ownership.

Overlay maps were prepared and reviewed. The review of the maps combined with the review of approved projects suggests that assemblage of a development site is not a great problem, but there are many areas where the lack of currently available sewer could be a problem. Since the overlay method was quick and intuitive, it did not lend itself to quantifiable results.

\section{B.7) Zoning Analysis: Density Range of Bonus Units}

Previous Commission staff work during municipal conformance activities produced tabulations of the number of developable acres by municipality and zone. This information was combined with information on the base and bonus densities permitted by zoning ordinances to derive an estimate of the number of bonus units that were available in various density ranges. This took account of the fact that some bonus units could be built at relatively low densities, while others could only be achieved if density were much higher.

of course, if, on a particular site, a high density were used, all of the units (base, lower density bonus units, and high density units alike) would be built at the higher density. The table produced by this analysis does indicate where large numbers of bonus units are concentrated in higher density ranges. This may be important, if, as has been suggested, higher density development-is relatively unlikely to occur within the Pinelands.

\section{B.8) Zoning Analysis: Bulk Standards}

It is known that bulk standards such as minimum lot size, lot width and depth, set back requirements, open space requirements, and the like can interfere with the achievement of densities stated in a zoning ordinance. It was necessary to determine whether such standards were a material impediment to the 
achievement of PDC bonus densities in certified zoning ordinances.

Lane Kendig, Inc., a planning firm which had conducted similar analysis of Hamilton Township's ordinance was asked to assist in this task. The consultant was given the task of interpreting ordinance standards with the assistance of computer software to determine whether bulk standards of selected municipalities interfered with density.

Regional Growth Area zoning ordinances were ranked based on the total number of PDC bonus units provided, the number of bonus units that depended on densities above $4 \mathrm{du} / \mathrm{ac}$, and the number of bonus units that depended on PUD provisions of the zoning ordinances. Based on the ranking, five municipal ordinances were selected for bulk standards analysis.

These ordinances were then reviewed in detail and relevant standards (e.g. lot size and yard requirements, open space standards, housing type and mix requirements) were extracted for analysis. Where necessary, standard assumptions regarding efficiency of site utilization, etc. were made as part of the analysis.

\section{B.9) Market Study}

Actual housing sales data was collected, for the dual purpose of providing an indication of the housing market, and to provide empirical data to perform the economic analysis described below.

The professionals involved in the roundtable had stressed the importance of looking, in a market study, outside of the Pinelands as well as inside. The view was generally shared by professionals familiar with the housing market in New Jersey that there were three major housing markets that should be represented. These included I) Ocean County, with a historical emphasis on retirement housing, but recent trends toward housing to serve $\bar{a}$ growing employment base, 2) the Atlantic City area, with a growing employment base, and 3 f the western tier of South Jersey communities, being outer suburbs of the Philadelphia metropolitan area and Trenton. The potential for some influence from the growth of the Princeton/Route 1 corridor was discussed; it was felt that some influence from that area may be felt but that it was less important than the three other factors identified.

To represent these markets, four municipalities were selected for data collection. These were Jackson Township in Ocean County, Galloway Township in Atlantic County, Winslow Township in Camden 
County, and Medford Township in Burlington County. Contact was made with the tax assessors and Planning Board Secretaries in each of the selected communities. Assessors and Planning Board Secretaries were cooperative and helpful in providing advice and access to needed records. They were also able to serve as knowledgeable resource persons regarding the locations of certain neighborhoods and major developments.

For each selected community, sales were identified using SRI-A forms in the assessor's office. Assessor's codes on the forms enabled identification of sales of new homes. A master list of new home sales during 1987 was compiled in each municipality except Medford, where 1986 and 1987 were used due to the much smaller number of sales. The goal was to obtain 200 valid sample points from each municipality. In each municipality except for Medford, far more than 200 new home sales were listed for 1987 , so a systematic sample of 200 sales was drawn for detailed data collection. For Medford, all new sales for 1986 and 1987 were included.

For the selected sample, the assessor's property records were consulted, and a range of data recorded. The data recorded included the sale date, sale price, square footage of floor area, size of lot, and any notable amenities such as waterfront

location. For units which were identifiably part of a major development, the major parameters of the development were recorded, including the overall density, the density of the phase or section, and the presence of recreational or amenity features. Municipal tax maps were used to determine, for each sale, whether it was within or outside of the Pinelands.

Data was entered into microcomputer files, was tabulated and summarized as part of the market analysis, and was formatted for use in the economic analysis.

The use of actual sales data was selected over certain other possibilities, such as a survey of active real estate developments currently advertising, because it was felt that it would be more objective. In preparation-for this phase of the study, a housing market report prepared by Gloucester county was reviewed. - It was noted that in a listing of active projects, high priced housing appeared to dominate the market, both in terms of the number of models offered, and the number of active projects. The same report provided a tabulation of actual sales data, and the price range of actual new unit sales was markedly lower than the listing of active projects would indicate. The decision to use empirical sales data appears to be a sound one, however, it may be noted that the selection of three 
municipalities with very active new housing markets leads to the inclusion of many units from a' limited number of large scale developments.

\section{B.10) Building Permit and Population Data.}

The New Jersey Department of Labor, Office of Demographic and Economic Analysis (ODEA) prepares several official reports that are useful. One of these is the annual summary of units authorized by building permits. Review of these annual summaries since 1980 provided a picture of the overall housing market in southern New Jersey, and provided a point of comparison in terms of the proportion of housing types in the sales data collection versus the proportion built in the regional housing market.

Two other useful reports are ODEA's Population Estimates and Population Projections. While the Pinelands Comprehensive Management Plan does not directly relate to development within a particular time horizon, it is necessary when viewing the PDC program to have some assurance that a reasonably vigorous housing market will exist. official estimates and projections of population growth were consulted for this purpose.

\section{B.11) Economic Analysis}

It was recognized that whatever other factors may be important to the functioning of the PDC program, a minimum condition is that it be economically rational to purchase a PDC in order to build at a higher than base density.

Dr. James C. Nicholas was retained to perform an economic analysis of the value of a PDC for a range of base and bonus densities. Dr. Nicholas had previously conducted a pro-forma based analysis of the PDC program as part of the Commission's Economic Analysis of the Pinelands Comprehensive Management Plan, and provided similar assistance to Burlington County. He has also conducted analysis of the value of transferable development rights in a-number of other programs in the United states.

The approach used for this research task was essentially to perform a multiple regression on the empirical sales data, and combine that with information from the assessor's handbook on construction costs. This enabled the effects of each variable on the price of the unit to be isolated followed by the deduction of improvement and construction costs from the value of the land.

The analysis resulted in a matrix showing the value of each additional bonus unit for various base and bonus densities. 
These values were determined with the assumption that medium and higher density housing was improved in attractiveness through the provision of some amenities such as recreational facilities within the development. The sales data analyzed supported this assumption since amenities were commonly present for developments with densities above $4 \mathrm{du} / \mathrm{ac}$. It should be noted, however, that the absence of amenities would result in a lower PDC value in these developments.

The values were then discounted by 508 to account for the obvious fact that a developer or builder would not be willing to pay 1008 of the purely economic value of the added unit. The level of discount is, of course, judgmental, but a 508 discount results in an equal sharing of the value between a developer and a PDC owner.

It is also extremely important to recognize that the analysis is indicative rather than precise. Since it is sensitive to a number of factors which are peculiar to individual sets of circumstances, the dollar estimates and their relationships to various densities are indicative of the magnitude of a PDC's worth in different development scenarios. 


\section{DATA AND FINDINGS}

\section{A. PDC SALES AND PURCHASES}

Sales and purchases reported by the Burlington County PDC Bank and contained in Pinelands Commission files were reviewed and tabulated to determine the magnitude of the market in PDCs to date, and the trend in sales and purchases.

Table 1. PDCs Sold by Landowners

\begin{tabular}{lrrr} 
& $\begin{array}{r}\text { Purchased by } \\
\text { Burlington } \\
\text { County PDC } \\
\text { Credit Bank }\end{array}$ & $\begin{array}{r}\text { Purchased } \\
\text { by } \\
\text { Private } \\
\text { Party }\end{array}$ & Total \\
Year & 4.50 & 5.50 & 10.00 \\
1982 & 35.50 & & 35.50 \\
1983 & 26.75 & 26.75 \\
1984 & 7.25 & 7.25 \\
1985 & 4.50 & 4.50 \\
1986 & 2.25 & 2.25 \\
1987 & 10.00 & 10.00 \\
1988 & 90.75 & 5.50 & 96.25 \\
\hline-901 & & &
\end{tabular}

Note: 1988 through $8 / 3$

Purchases by the Burlington County PDC Bank peaked in 1983 and declined thereafter, until 1988. At mid year 1988 purchases were awaiting closing on 10 PDCs, the most purchased in a single year since 1984 .

Including the 1988 purchases pending, a total of 90.75 PDCs have been acquired by the Burlington County PDC Bank, and 2,727.9 acres of land have been protected by deed restrictions.

A single private transaction in 1982 accounted for the sale of an additionaI 5.5 PDCs, resulting in 471 acres of land being protected by easement. The combined totals through August 1988 are 96.25 PDCs sold from land, resulting in $3,198.9$ acres of land protected by easements. 
Table 2. - PDCs Purchased by Developers

\begin{tabular}{lrrr} 
& $\begin{array}{r}\text { Purchased } \\
\text { from } \\
\text { Burlington } \\
\text { County PDC } \\
\text { Credit Bank }\end{array}$ & $\begin{array}{r}\text { Purchased } \\
\text { from } \\
\text { Private } \\
\text { Party }\end{array}$ & Total \\
Year & 2.25 & & 2.25 \\
\hline 1984 & 1.25 & 0.75 & 2.00 \\
1985 & 6.50 & 4.75 & 11.25 \\
1986 & 9.50 & 9.50 \\
1987 & 21.50 & & 21.50 \\
1988 & 41.00 & 5.50 & 46.50 \\
\hline Total & & &
\end{tabular}

Note: 1988 through $8 / 3$

PDCs sold to date have been sold to intermediate parties rather than directly to a developer who will redeem them. As a consequence, the trend in purchases has been different from the trend in sales. Developers' purchases of PDCs for actual redemption began only in 1984, and has shown an upward trend since then.

All of the PDCs sold to the private parties have been purchased by developers. The Burlington County PDC Bank has resold 41 of the 90.75 credits it purchased, leaving it with a balance of 48.25 credits available to auction.

\section{B. LETTERS OF INTERPRETATION}

A Letter of Interpretation records the number of PDCs allocated to a particular parcel of land. While it is not necessary for a landowner to obtain a Letter of Interpretation in order to negotiate regarding sale of PDCs, it is a reasonable assumption that most landowners would want to obtain the Letter early in the process in order to know precisely how many credits are owned, and to save-time in the transaction. Allocation of PDCs through Letters of Interpretation, then, is indicative of landowner interest in selling PDCs, though it must be assumed that the total interest or willingness to sell is understated since the Letter is not a necessity until the PDC is actually sold. Two tables have been prepared; Table 3 shows the number of Letters and the number of PDCs allocated by year, and Table 4 shows the number of Letters and the number of PDCs by the number of PDCs allocated. 
Table 3. Allocation of PDCs by Year

\begin{tabular}{|c|c|c|}
\hline Year & $\begin{array}{r}\text { Number of } \\
\text { Letters of } \\
\text { Interpretation }\end{array}$ & $\begin{array}{c}\text { Number of } \\
\text { PDCs } \\
\text { Allocated }\end{array}$ \\
\hline $\begin{array}{l}1981 \\
1982 \\
1983 \\
1984 \\
1985 \\
1986 \\
1987\end{array}$ & $\begin{array}{r}7 \\
24 \\
37 \\
34 \\
22 \\
22 \\
6\end{array}$ & $\begin{array}{r}83.00 \\
171.75 \\
128.11 \\
55.63 \\
30.76 \\
21.32 \\
9.51\end{array}$ \\
\hline Total & 152 & 500.08 \\
\hline
\end{tabular}

Through 1987, a total of 152 Letters of Interpretation had been issued allocating a total of 500.08 PDCs. The number of Letters of Interpretation peaked in 1983 with 37 , while the number of PDCs allocated peaked in 1982 with 171.75 .

Since 1983, the trend in both the number of Letters of Interpretation and the number of PDCs allocated has been on the decline.

Table 4. Letters of Interpretation by Number of PDCs

\begin{tabular}{lrr} 
Number of PDCs & $\begin{array}{r}\text { Number of } \\
\text { Letters }\end{array}$ & Number of \\
\hline PDCs
\end{tabular}

79 out of 152 Letters of Interpretation allocated less than 1 PDC. These 79 Letters of Interpretation allocated a total of 24.57 PDCs.

20 Letters of Interpretation allocated 5 or more PDCs, for a total of 367 PDCs. 
C. STATUS REPORTS ON PROJECTS USING PDCS

Table 5. Status of Projects Using PDCs

$$
4 / 85 \quad 3 / 86 \quad 4 / 87 \quad 4 / 88 \quad 8 / 88
$$

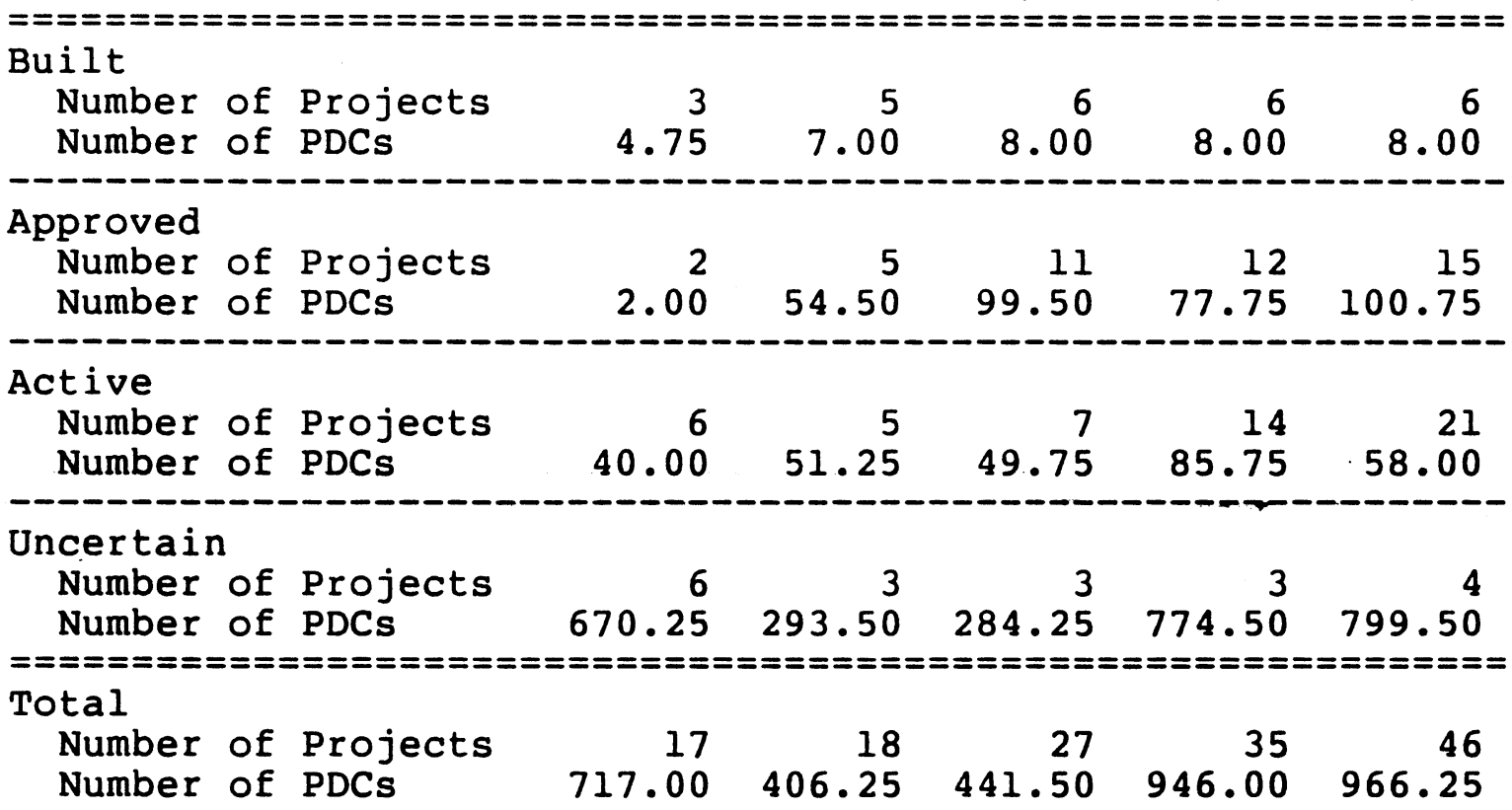

In the last three years, the number of PDCs included in built and approved projects has increased dramatically, from 6.75 to 108.75. So too have the number of projects, which stood at 5 in 1985 but had increased to 21 in 1988 . These reports have classified projects as "built" only when they are entirely built. This may understate the number of units that have been built using PDCs, since a number of approved projects are under construction, and have resulted in PDC purchases. Nevertheless, for the purpose of establishing a time series the "built" category includes only completely built projects.

In the past year, however, the trend has flattened out. Although the number of projects continues to increase, the number of PDCs in approved and built projects has only increased by 1.25 since 1987. When combined with active projects, the number of PDCs has increased from 157.25 to 166.25 during the same period.

The category of "uncertain" projects is very volatile but is indicative of developers' interest in PDCs. A steady upward trend in the number of projects is suggestive of increasing interest within the development community but it is not advisable 
to attach great significance to the potential number of PDCs since project designs are very' conceptual at this point and may be significantly revised as developers proceed to more detailed phases of planning.

\section{DENSITY OF APPROVED PROJECTS}

A list of projects consisting of at least 10 dwelling units with Pinelands approval was drawn from the development review tracking computer file in August of 1988. A total of 51 of these were analyzed for base units, PDC units, and gross density. These are listed in Table 7, and summarized in Table 6, below.

A subset of 29 projects listed in May of 1988 was analyzed in more detail, including wetland and wetland buffer acreage, and units permitted by zoning, and PDC units permitted versus PDC units approved.

Table 6. Projects and Units by Gross Density: Summary of Long List of Approved Projects

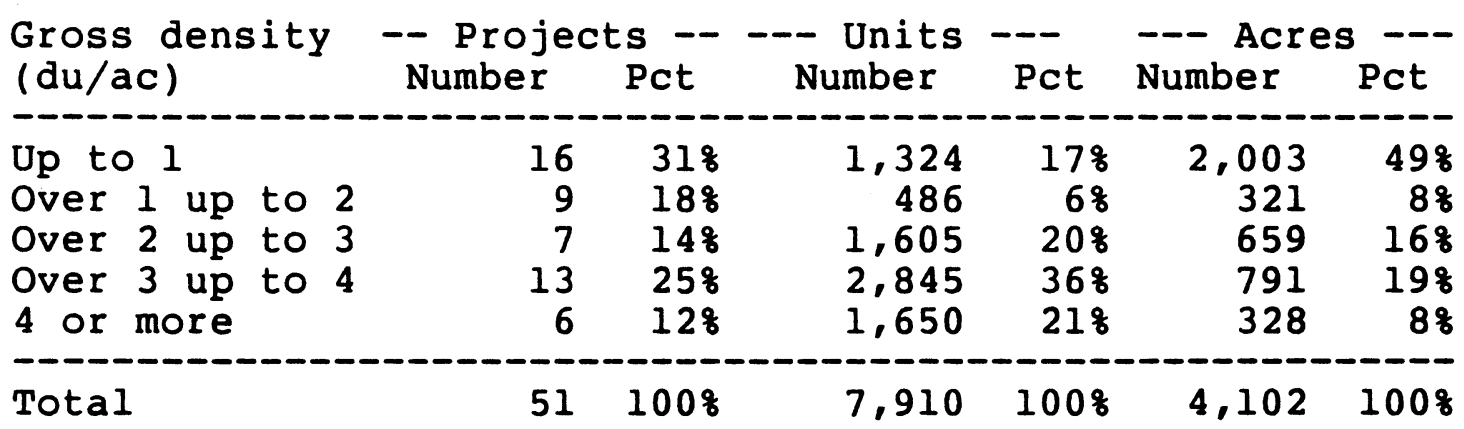

Of the 51 projects listed, 6 were approved at gross densities of $4 \mathrm{du} / \mathrm{ac}$ or more. These 6 projects were 128 of the number of projects, but included 218 of all of the units, and consumed 88 of the land.

19 projects were approved at gross densities of $3 \mathrm{du} / \mathrm{ac}$ or more. These represented $37 \%$ of the projects, $57 \%$ of the units, and $27 \%$ of the land.

32 projects were approved at gross densities of less than $3 \mathrm{du} / \mathrm{ac}$. These represented 638 of the projects, 438 of the units, and 738 of the land.

The 16 projects approved at gross densities of less than $1 \mathrm{du} / \mathrm{ac}$ represented 498 of all of the land consumed. 
Table_ 7 . Approved Applications: Acres, Onits, Gross Density

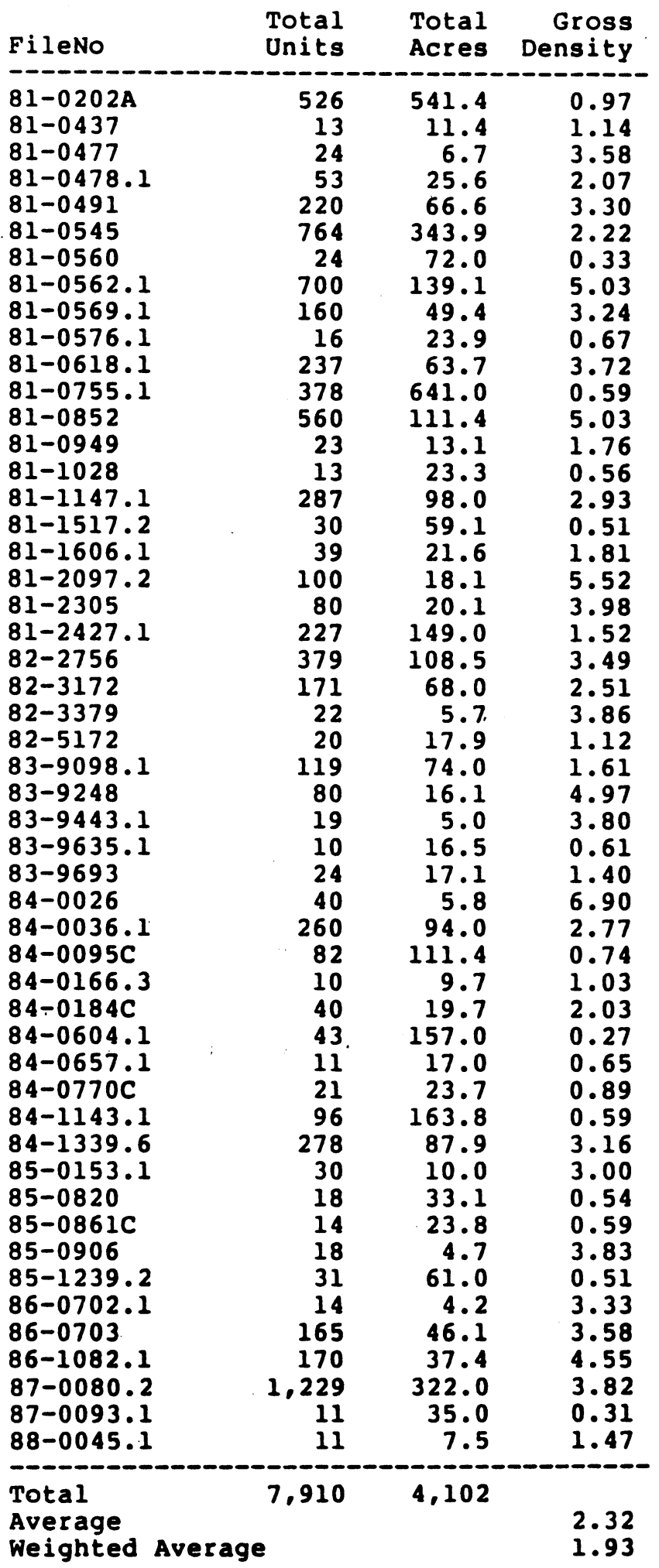




\section{E. USE OF PDCS IN APPROVED PROJECTS}

A list of approved residential development projects with at least 10 dwelling units in Regional Growth Areas was extracted from the Commission's development review computer files in August. The number of base units, PDC bonus units and total units were tabulated, for the purpose of indicating how much of total approved Regional Growth residential development will involve PDCs. The total number of PDCs in approved projects in Table 8 differs from the number in the PDC projects status report because developments with fewer than 10 units are not included and other projects approved before 1985 may not be included.

From the 1 ist of 51 projects, 11 projects use at least some PDCs.

Out of a total of 7,879 units in the approved projects, 289, or 3.78 were PDC bonus units. 
Table 8. Approved Applications: Base and PDC Onits

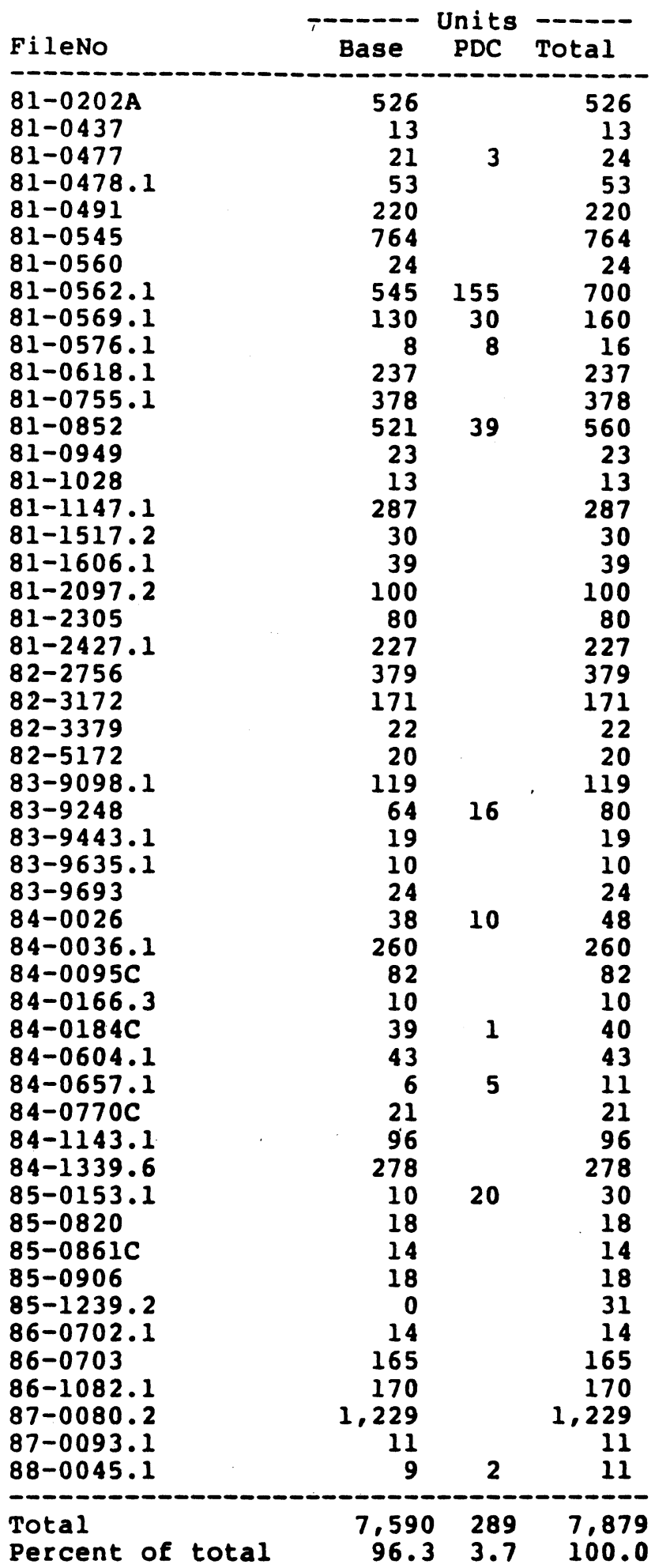


F. PERMITTED AND ACTUAL UNITS IN APPROVED PROJECTS

Residential development projects with at least 10 dwelling units in Regional Growth Areas listed in the April computer report were analyzed in detail. The analysis included the number of base and PDC bonus units that appeared to be permitted by zoning, compared to the actual number of base and bonus units approved. From this analysis, the number of base and bonus units not used was estimated.

From the list of 27 projects that were analyzed in detail, 4 projects used PDCs. A total of 3,432 units were approved, of which 69 , or 28 were PDC bonus units. The 69 actual PDC units represent 3.28 of the theoretically possible 2,165 PDC units; 96.88 of the theoretically possible bonus units were not used.

The 3,4.3.2 units approved represented 54.98 of possible maximum development; 45.18 of possible development potential was not used. The 3,363 base units represented 82.318 of possible base units; 17.78 of possible base units were not used. 
Table 9. Approved Projects: Permitted and Actual Units

\begin{tabular}{|c|c|c|c|c|}
\hline FileNo & $\begin{array}{r}\text { Actual } \\
\text { Base } \\
\text { Units }\end{array}$ & $\begin{array}{r}\text { Actual } \\
\text { PDC } \\
\text { Units }\end{array}$ & $\begin{array}{r}\text { Base } \\
\text { Units } \\
\text { Not } \\
\text { Used }\end{array}$ & $\begin{array}{r}\text { PDC } \\
\text { Units } \\
\text { Not } \\
\text { Used }\end{array}$ \\
\hline $\begin{array}{l}81-0202 A \\
81-0437 \\
81-0477 \\
81-0491 \\
81-0545 \\
81-0560 \\
81-0852 \\
81-0949 \\
81-1028 \\
81-1517.2 \\
81-2305 \\
82-2756 \\
82-3172 \\
82-3379 \\
83-9248 \\
83-9693 \\
84-0026 \\
84-0095 \mathrm{C} \\
84-0166.3 \\
84-0184 \mathrm{C} \\
84-0770 \mathrm{C} \\
84-1143.1 \\
85-0820 \\
85-0861 \mathrm{C} \\
85-0906 \\
85-1239.2 \\
86-0703\end{array}$ & $\begin{array}{r}526 \\
13 \\
21 \\
220 \\
764 \\
24 \\
529 \\
23 \\
13 \\
30 \\
80 \\
379 \\
171 \\
22 \\
64 \\
24 \\
38 \\
82 \\
10 \\
39 \\
21 \\
24 \\
18 \\
14 \\
18 \\
31 \\
165\end{array}$ & $\begin{array}{r}0 \\
0 \\
3 \\
0 \\
0 \\
0 \\
39 \\
0 \\
0 \\
0 \\
0 \\
0 \\
0 \\
0 \\
16 \\
0 \\
10 \\
0 \\
0 \\
1 \\
0 \\
0 \\
0 \\
0 \\
0 \\
0 \\
0\end{array}$ & $\begin{array}{r}250 \\
1 \\
0 \\
96 \\
86 \\
21 \\
0 \\
0 \\
1 \\
5 \\
0 \\
55 \\
67 \\
1 \\
0 \\
0 \\
0 \\
0 \\
2 \\
0 \\
9 \\
79 \\
12 \\
0 \\
3 \\
14 \\
20\end{array}$ & $\begin{array}{r}400 \\
11 \\
0 \\
163 \\
319 \\
27 \\
228 \\
13 \\
0 \\
0 \\
80 \\
217 \\
119 \\
17 \\
48 \\
17 \\
0 \\
0 \\
10 \\
38 \\
22 \\
61 \\
30 \\
0 \\
0 \\
23 \\
185\end{array}$ \\
\hline Tōtal & 3,363 & 69 & 723 & 2,096 \\
\hline
\end{tabular}




\section{G. BUILDING PERMIT SUMMARIES}

Annual summaries of units permitted by building permits were obtained from the New Jersey Department of Labor. The total number of units and the number of single family units permitted were tabulated by year from 1980 through 1987. (See Table 10.) This tabulation provides an indication of the trend in total residential construction in counties containing Pinelands Regional Growth Areas and the mix of single and multi-family construction. It should be noted that the Department of Labor data includes townhouses in the single family category.

For Pinelands Counties, NJDL Building Permit summaries indicate that roughly $70 \%$ of units authorized have been "single family" (includes detached and townhouse); 308 have been 2 or more family.

Annual totals in units permitted clearly show the effect of the housing recession in the early $1980^{\prime} \mathrm{s}$. The total number of units per year for 1980 through 1982 was roughly 8,000 for the five counties. Since 1982 the trend has been upward, with totals for 1986 and 1987 in excess of 21,000 units permitted per year. 
Table 10. Residential Onits Authorized by Building Permits

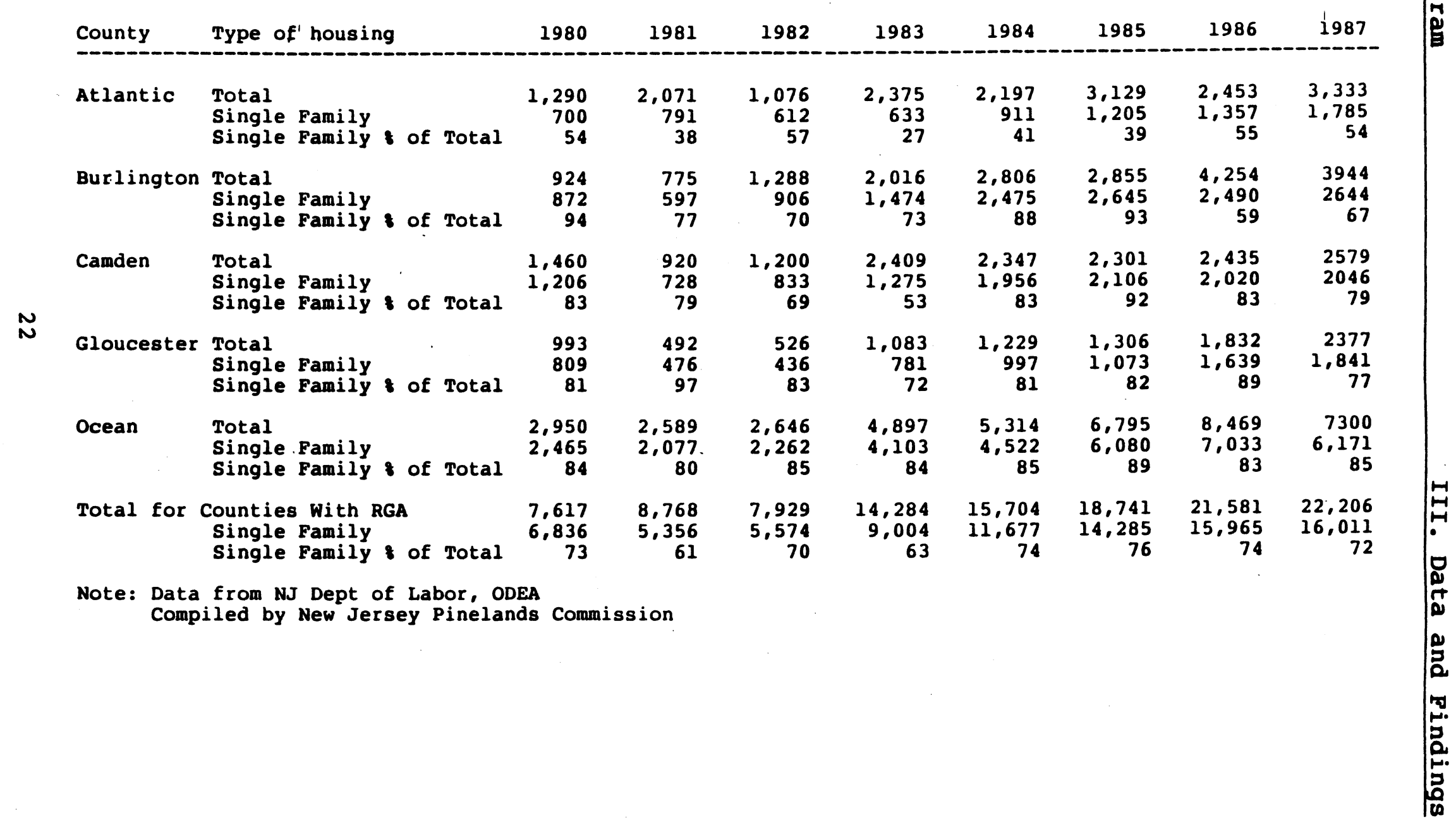




\section{H. SALES DATA FOR FOUR SELECTED MUNICIPALITIES}

\section{H.1) Sales by Municipality and Weighting Factors}

Actual sales data was collected from assessors' records in the four selected municipalities. It was desired to collect sufficient data from each municipality to represent a regional sub-market. The desired number of sales per municipality was 200. Sales were selected from the list of all new sales for the year 1987 in three of the municipalities. The exception was Medford, where the total number of sales per year was much lower than in the other three, and all new house sales for the years 1986 and 1987 were included.

The total number of new sales per year differs among the municipalities. For the purpose of deriving composite data which describe all four municipalities, the raw data was weighted in accordance with the number of raw data points and the number of new sales in 1987, as shown in Table 11 .

The number of actual sales for 1987 -ranged from a low of 83 for Medford to a high of 909 for Galloway. The number of data points collected was 153 for Medford and 200 for each of the other municipalities. The ratio of the number of sales to the number of data points provides a weighting factor that may be applied to data to develop a composite "combined" total that represents the sum of the four municipalities.

Table 11. Data Points, New Home Sales, and Weighting Factors

Medford Winslow Galloway Jackson Total

\begin{tabular}{lccccc}
$\begin{array}{l}\text { Number of } \\
\text { Data Points }\end{array}$ & 153 & 200 & 200 & 200 & 753 \\
$\begin{array}{l}\text { Number of } \\
1987 \text { New Sales }\end{array}$ & 83 & 299 & 909 & 754 & 2,045 \\
$\begin{array}{l}\text { Weighting Factor } \\
\text { (sales/data points) }\end{array}$ & 0.542 & 1.495 & 4.545 & 3.770 & \\
\hline
\end{tabular}


H.2) Sales by Pinelands and Non-Pinelands Location

Table 12. Pinelands/Non-Pinelands Location

\begin{tabular}{|c|c|c|c|}
\hline & Pinelands & $\begin{array}{r}\text { Non- } \\
\text { Pinelands }\end{array}$ & Total \\
\hline $\begin{array}{l}\text { Medford } \\
\text { Number } \\
\text { Percent }\end{array}$ & $\begin{array}{c}113 \\
73.98\end{array}$ & $\begin{array}{c}40 \\
26.18\end{array}$ & $\begin{array}{c}153 \\
100.08\end{array}$ \\
\hline $\begin{array}{l}\text { Winslow } \\
\text { Number } \\
\text { Percent }\end{array}$ & $\begin{array}{c}22 \\
11.08\end{array}$ & $\begin{array}{c}178 \\
89.08\end{array}$ & $\begin{array}{c}200 \\
100.08\end{array}$ \\
\hline $\begin{array}{l}\text { Galloway } \\
\text { Number } \\
\text { Percent }\end{array}$ & 3.08 & $\begin{array}{c}194 \\
97.08\end{array}$ & $\begin{array}{c}200 \\
100.08\end{array}$ \\
\hline $\begin{array}{l}\text { Jackson } \\
\text { Number } \\
\text { Percent }\end{array}$ & $\begin{array}{c}5 \\
2.58\end{array}$ & $\begin{array}{c}195 \\
97.58\end{array}$ & $\begin{array}{c}200 \\
100.0 \%\end{array}$ \\
\hline $\begin{array}{c}\text { Weighted Total } \\
\text { Number } \\
\text { Percent }\end{array}$ & $\begin{array}{l}140 \\
6.98\end{array}$ & $\begin{array}{c}1,905 \\
93.18\end{array}$ & $\begin{array}{l}2,045 \\
100.08\end{array}$ \\
\hline
\end{tabular}

73.98 of the data points collected for Medford were within the Pinelands. For Winslow, new sales in the Pinelands were 118 of the total, for Galloway, 3\%, and for Jackson, 2.5\%. For the weighted total, 6.98 of the new sales were in the Pinelands Area.

In Galloway, the sales not within the Pinelands Area were within the CAFRA area, and were therefore subject to somewhat similar environmental performance standards. By contrast, non-Pinelands areas of Winslow and Jackson were not subject to any comparable environmental -standards. 


\section{H.3) Housing Type}

Table 13. Housing Type by Municipality

\begin{tabular}{lrrrrr} 
& & & \multicolumn{2}{c}{ Weighted } \\
Type & Medford & Winslow Galloway Jackson & Total \\
\hline Single Detached & 77.18 & 71.58 & 18.58 & 33.08 & 34.08 \\
Townhouse & 0.08 & 28.58 & 15.08 & 33.08 & 23.08 \\
Condo/apt & 22.98 & 0.08 & 66.58 & 34.08 & 43.08 \\
\hline & 100.08 & 100.08 & 100.08 & 100.08 & 100.08
\end{tabular}

In Medford, except for one project which consisted of remodeling pre-existing apartments for sale as condominiums, all new housing was single family detached.

In winslow, 71.58 of new housing was single family detached; the balance was townhouse.

In Galloway, 66.58 of new housing was condo/apartment; the balance was split between single family detached (18.5\%) and townhouse (158).

In Jackson, new housing was split virtually equally among the three housing types, single family detached (33\%), townhouse (33\%), and condo/apartment (348).

For the weighted total, 57 of new housing was single detached or townhouse. This may be contrasted with 708 for those housing types reported by NJDL/ODEA building permit data for the counties with Pinelands Regional Growth Areas.

\section{H.4) Gross Density by Municipality}

In the collection of sales data; density was recorded for major developments both for the individual section or phase, and for the entire-development. Densities are often higher for individual sections than for the development, but the economic analysis required the use of the gross density for the entire development. In addition, most density based analysis for the Pinelands RGA zones relies upon gross density. It should be noted that gross density is sensitive to the presence of wetlands; i.e. low gross density may suggest that a development is single family detached when it is actually cluster townhouses or condominium apartments. 
Table 14. Gross Density of New Housing by Municipality

\begin{tabular}{|c|c|c|c|c|c|c|}
\hline $\begin{array}{r}\text { At } \\
\text { Least }\end{array}$ & $\begin{array}{l}\text { Less } \\
\text { Than }\end{array}$ & Medford & Winslow & Galloway & Jackson & $\begin{array}{l}\text { Weighted } \\
\text { Total }\end{array}$ \\
\hline $\begin{array}{r}0 \\
0.5 \\
1 \\
2 \\
3 \\
4 \\
6 \\
8 \\
10\end{array}$ & $\begin{array}{r}0.5 \\
1 \\
2 \\
3 \\
4 \\
6 \\
8 \\
10 \\
12\end{array}$ & $\begin{array}{r}11.18 \\
59.58 \\
5.28 \\
1.38 \\
0.08 \\
0.08 \\
22.98 \\
0.08 \\
0.08\end{array}$ & $\begin{array}{r}0.08 \\
2.08 \\
10.58 \\
20.58 \\
18.08 \\
4.08 \\
36.08 \\
8.08 \\
1.08\end{array}$ & $\begin{array}{r}0.58 \\
2.58 \\
10.08 \\
73.58 \\
3.08 \\
1.08 \\
0.08 \\
0.08 \\
9.58\end{array}$ & $\begin{array}{r}1.58 \\
9.58 \\
11.58 \\
9.58 \\
1.08 \\
48.08 \\
19.08 \\
0.08 \\
0.08\end{array}$ & $\begin{array}{r}1.28 \\
7.38 \\
10.48 \\
39.28 \\
4.38 \\
18.78 \\
13.28 \\
1.28 \\
4.48\end{array}$ \\
\hline & & & & 100.08 & 100.08 & 100.08 \\
\hline
\end{tabular}

In Medford, 22.98 of units were sold at 6-8 du/ac; these were condo/apt units and were not within the Pinelands. 70.68 of units were built at less than $1 \mathrm{du} / \mathrm{ac}$.

In Winslow 498 of units were built in the density ranges of $1-4$ $\mathrm{du} / \mathrm{ac}$. $36 \%$ were built in the range of 6-8 du/ac.

In Galloway, 73.58 of units were built in the density range of 2-3 du/ac. $86.5 \%$ were built at densities of less than $3 \mathrm{du} / \mathrm{ac}$. 9.58 of units were built at a density of 10-12 du/ac; this

appears to be due to one development near U.S. Route 30 .

In Jackson, 30.58 of units were built in the .5 to $3 \mathrm{du} / \mathrm{ac}$ range; another $67 \%$ percent were built in the 4-8 du/ac range.

\section{H.5) Gross Density by Pinelands and CAFRA Location}

There is a-significant difference in the density of development that is located in either the Pinelands area or the CAFRA area compared to development located elsewhere. This largely accounts for density differences among the municipalities. The one condo/apartment project in Medford is outside of the Pinelands and is at higher density than projects in Medford within the Pinelands. Most development in Galloway is within the CAFRA area, and is subject to extensive environmental review. Most development in Winslow and Jackson are within neither the 
Pinelands nor- CAFRA areas. The percentage of sales by density is compared for Pinelands and CAFRA areas versus other areas in Table 15.

Table 15. Density of New House Sales by Location in Pinelands or CAFRA Areas

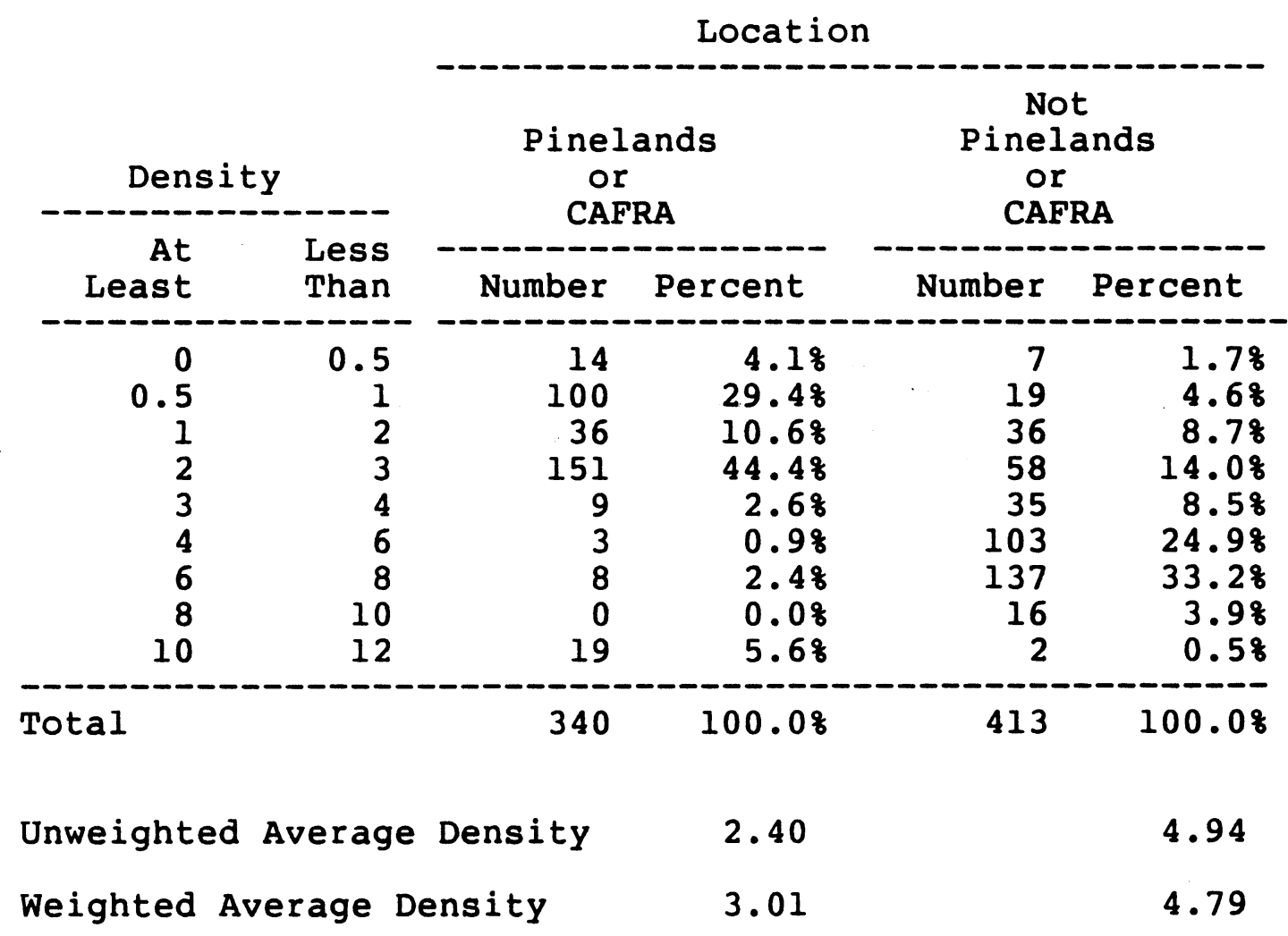

Within the Pinelands or CAFRA areas $88.5 \%$ of units were built at gross densities of less than 3 du/ac. The major exception was Concord at Galloway, which-accounted for 9.58 of Galloway's units being in the 10-12 density range; Concord is within the CAFRA area.

The weighted average density of development within the Pinelands or CAFRA areas was 3.01 du/acre; by contrast, the weighted average density for development outside of those areas was 4.79 du/acre. 


\section{H.6) Floor Area}

Floor area of a unit accounts for a major portion of the price of the unit. The distribution of floor areas is also an important factor in describing the housing market in an area.

Table 16. Floor Area in Square Feet

Floor Area Sq Ft. Percent of Units

\begin{tabular}{|c|c|c|c|c|c|c|}
\hline $\begin{array}{r}\text { At } \\
\text { Least }\end{array}$ & $\begin{array}{l}\text { Less } \\
\text { Than }\end{array}$ & Medford & Winslow & Galloway & Jackson & $\begin{array}{r}\text { Weighted } \\
\text { Total }\end{array}$ \\
\hline $\begin{array}{r}500 \\
750 \\
1,000 \\
1,250 \\
1,500 \\
2,000 \\
2,500 \\
3,000\end{array}$ & $\begin{array}{r}750 \\
1,000 \\
1,250 \\
1,500 \\
2,000 \\
2,500 \\
3,000 \\
9,999\end{array}$ & $\begin{array}{r}0.08 \\
7.88 \\
1.5 .08 \\
0.08 \\
1.38 \\
3.98 \\
23.58 \\
48.48\end{array}$ & $\begin{array}{r}45.58 \\
32.58 \\
20.08 \\
2.08 \\
0.08 \\
0.08 \\
0.08 \\
0.08\end{array}$ & $\begin{array}{r}0.08 \\
31.08 \\
39.58 \\
20.08 \\
8.58 \\
1.08 \\
0.08 \\
0.08\end{array}$ & $\begin{array}{r}0.08 \\
22.58 \\
23.08 \\
20.08 \\
15.08 \\
17.08 \\
2.58 \\
0.08\end{array}$ & $\begin{array}{r}6.78 \\
27.18 \\
29.68 \\
16.68 \\
9.48 \\
6.98 \\
1.98 \\
2.08\end{array}$ \\
\hline & & 100.08 & $100.0 \%$ & 100.08 & 100.08 & 100.08 \\
\hline
\end{tabular}

In Medford, 71.98 of units had floor area over $2,500 \mathrm{sq}$ ft.; 48.48 had floor area over $3000 \mathrm{sq} f t$. $22.8 \%$, attributable to the condo/apts, had floor area between 750 and $1,250 \mathrm{sq} \mathrm{ft}$.

In Winslow, $98 \%$ of units had floor area less than 1,250 sq ft.; 458 had floor area in the 500-750 sq $\mathrm{ft}$. range.

In Galloway $59.5 \%$ of units were in the 1,000-1,500 sq $\mathrm{ft}$. range, and $31 \%$ were in the 750-1,000 sq $\mathrm{ft}$. range.

Units in Jackson were the most evenly distributed across a variety of ranges with few units in the extremely large or small categories- 45.58 of units were in the ranges of $750-1,250 \mathrm{sq}$ ft. 528 of units were in the ranges of $1,250-2,500 \mathrm{sq} \mathrm{ft}$.

In the weighted total, 73.38 of units were in the range of 750 to $1,500 \mathrm{sq} f t$. 


\section{H.7) Price Range}

Table 17. Price Range of New Home Sales

\begin{tabular}{|c|c|c|c|c|c|c|}
\hline \multicolumn{2}{|c|}{ Price } & \multicolumn{5}{|c|}{ Percent of Units } \\
\hline $\begin{array}{r}\text { At } \\
\text { Least }\end{array}$ & $\begin{array}{l}\text { Less } \\
\text { Than }\end{array}$ & Medford & Winslow & Galloway & Jackson & $\begin{array}{r}\text { Weighted } \\
\text { Total }\end{array}$ \\
\hline $\begin{array}{r}50,000 \\
75,000 \\
100,000 \\
125,000 \\
150,000 \\
200,000 \\
400,000\end{array}$ & $\begin{array}{r}75,000 \\
100,000 \\
125,000 \\
150,000 \\
200,000 \\
400,000 \\
700,000\end{array}$ & $\begin{array}{r}17.48 \\
6.78 \\
0.78 \\
1.38 \\
12.18 \\
55.78 \\
6.08\end{array}$ & $\begin{array}{r}43.08 \\
46.08 \\
10.08 \\
1.08 \\
0.08 \\
0.08 \\
0.08\end{array}$ & $\begin{array}{r}68.58 \\
22.58 \\
7.08 \\
2.08 \\
0.08 \\
0.08 \\
0.08\end{array}$ & $\begin{array}{r}11.08 \\
46.58 \\
16.58 \\
10.58 \\
13.58 \\
2.08 \\
0.08\end{array}$ & $\begin{array}{r}41.58 \\
34.28 \\
10.78 \\
5.08 \\
5.58 \\
2.98 \\
0.28\end{array}$ \\
\hline Total & & 100.08 & 100.08 & 100.08 & 10.0 .08 & $100.0 \%$ \\
\hline
\end{tabular}

In Medford, 55.7\% of units were in the $\$ 200,000$ to $\$ 400,000$ price range. 73.88 of units were priced at $\$ 150,000$ or more. Apart from the one condo/apt project, only $3.3 \%$ of units in Medford were priced below $\$ 150,000$.

In Winslow, $43 \%$ of units were priced in the $\$ 50,000-\$ 75,000$ range; another $46 \%$ were priced in the $\$ 75,000-\$ 100,000$ range. Only 18 of units were priced at $\$ 125,000$ or more.

In Galloway, 68.58 of units were priced in the $\$ 50,000-\$ 75,000$ range; another 22.58 were priced in the $\$ 75,000-\$ 100,000$ range. Only 28 of units were priced at $\$ 125,000$ or more.

In Jackson, 46.58 of units were priced in the $\$ 75,000$ to $\$ 100,000$ range. Otherwise, the pricing of units, like the range of floor areas, was spread over a range of values, roughly paralleling the range of floor areas.

For the werghted total, 41.58 of units were in the $\$ 50,000-\$ 75,000$ price range, 34.28 were in the $\$ 75,000-\$ 100,000$ price range, and 10.78 were in the $\$ 100,000$ to 125,000 price range. 10.58 were priced at $\$ 125,000$ to $\$ 200,000$. Only 3.18 were priced at $\$ 200,000$ or above. 


\section{ECONOMIC ANALYSIS}

A detailed description of the analysis, its findings and conclusions is presented in Appendix D. One of the more noteworthy analyses is presented in Table 18 which summarizes the discounted value of residential units added to a project as a result of a density increase. The table presents the discounted value of a bonus unit, so a value of $\$ 2,500$ in the table would be equivalent to a price of $\$ 10,000$ for a PDC. The values presented in Table 18 are $50 \%$ of the total value of the units since a developer would not be expected to seek a density increase if he was unable to retain at least a portion (or 508 in this case) of the increased economic value.

The use of $50 \%$ rather than some other discount is judgmental however, and it should be borne in mind that the relative values and the pattern of values is more important than the absolute value presented. Table 19 shows the relative values of bonus units, with 1,000 representing the highest value in the Table.

Discounted values ranged from $\$ 33,176$ per unit to zero, depending upon the beginning (from) and ending (to) density of a project.

Although the trend is not perfectly smooth, two general observations can be made:

- Discounted values per unit are relatively higher when density begins at a lower range (for example, a unit is worth more at an ending density of 4 du/acre if the beginning density is 1 du/ac rather than 2 or 3 du/acres.)

- Regardless of the beginning density, discounted values per unit are generally lower as the ending density increases (for example, a density increase from $2 \mathrm{du} / \mathrm{ac}$ to $3 \mathrm{du} / \mathrm{ac}$ yields a discounted per unit value of $\$ 4,343$ while an increase-from $2 \mathrm{du} / \mathrm{acre}$ to $4 \mathrm{du} / \mathrm{acre}$ yields $\$ 3,919$.$) An$ exception does occur, however, when beginning densities range from 4 to $6 \mathrm{du} / a c r e$. This is probably due to the effect of added amenities to developments at the higher densities.

The combined effect of these two phenomena is that per unit values generally decrease as both the beginning and ending density increase. In other words, the greatest values reside when beginning densities are in the lower ranges $(0.2$ to 3.0$)$ and 
the ending densities are also in the lower ranges 10.25 to 5 du/acre).

Although the precise values must be viewed with caution, the analysis clearly suggests that PDC prices ( 4 times the incremental value of each unit) in the $\$ 10,000$ or higher range are clearly realistic. 
Table 18: Value of One Bonus Onit Discounted 508

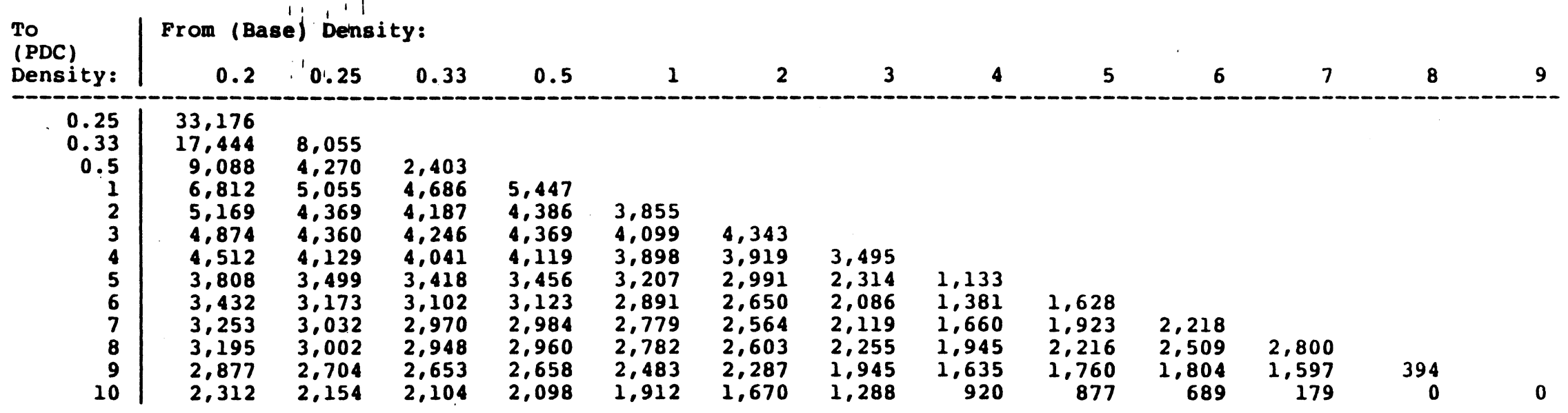


Table 19: Relative Value of One Bonus Onit

\begin{tabular}{|c|c|c|c|c|c|c|c|c|c|c|c|c|}
\hline $\begin{array}{l}\text { To } \\
\text { (PDC) } \\
\text { Density: }\end{array}$ & $\begin{array}{r}\text { From IBa } \\
0.2\end{array}$ & $\begin{array}{l}\text { IDens } \\
0.25\end{array}$ & $\begin{array}{l}1: \\
0.33\end{array}$ & 0.5 & 1 & 2 & 3 & 4 & 5 & 6 & 7 & 8 \\
\hline $\begin{array}{r}0.25 \\
0.33 \\
0.5 \\
1 \\
2 \\
3 \\
4 \\
5 \\
6 \\
7 \\
8 \\
9 \\
10\end{array}$ & $\begin{array}{r}1000 \\
526 \\
274 \\
205 \\
156 \\
147 \\
136 \\
115 \\
103 \\
98 \\
96 \\
87 \\
70\end{array}$ & $\begin{array}{r}243 \\
129 \\
152 \\
132 \\
131 \\
124 \\
105 \\
96 \\
91 \\
90 \\
82 \\
65\end{array}$ & $\begin{array}{r}72 \\
141 \\
126 \\
128 \\
122 \\
103 \\
94 \\
90 \\
89 \\
80 \\
63\end{array}$ & $\begin{array}{r}164 \\
132 \\
132 \\
124 \\
104 \\
94 \\
90 \\
89 \\
80 \\
63\end{array}$ & $\begin{array}{r}116 \\
124 \\
117 \\
97 \\
87 \\
84 \\
84 \\
75 \\
58\end{array}$ & $\begin{array}{r}131 \\
118 \\
90 \\
80 \\
77 \\
78 \\
69 \\
50\end{array}$ & $\begin{array}{r}105 \\
70 \\
63 \\
64 \\
68 \\
59 \\
39\end{array}$ & $\begin{array}{l}34 \\
42 \\
50 \\
59 \\
49 \\
28\end{array}$ & $\begin{array}{l}49 \\
58 \\
67 \\
53 \\
26\end{array}$ & $\begin{array}{l}67 \\
76 \\
54 \\
21\end{array}$ & $\begin{array}{r}84 \\
48 \\
5\end{array}$ & $\begin{array}{r}12 \\
0\end{array}$ \\
\hline
\end{tabular}




\section{J. DENSITY INCREASE OBTAINED THROOGH PDC USE}

The economic analysis suggests that a single marginal unit is worth more than a unit obtained through a substantial increase in density. A question therefore exists as to whether an imperceptible increase in density $(\mathrm{e} . \mathrm{g}$. the addition of 1 lot to a 100 lot subdivision) might actually represent the most attractive use for PDCs. If this is true, many of the opportunities to use PDCs for a more significant density increase might represent a theoretical potential which would never be realized. A sample of projects using PDCs was analyzed according to permitted base densities and actual densities to test the hypothesis.

Table 20. Density Increases Obtained Through PDC Use in Approved Projects

\begin{tabular}{|c|c|c|c|c|}
\hline FileNo & $\begin{array}{l}\text { Total } \\
\text { Acres }\end{array}$ & $\begin{array}{l}\text { Gross } \\
\text { Density } \\
\text { W/O PDCs }\end{array}$ & $\begin{array}{c}\text { Overall } \\
\text { Gross } \\
\text { Density }\end{array}$ & $\begin{array}{l}\text { Percent } \\
\text { Increase } \\
\text { In } \\
\text { Density }\end{array}$ \\
\hline $\begin{array}{l}81-0562.1 \\
81-0852 \\
81-0569.1 \\
85-0153.1 \\
83-9248 \\
81-0576.1 \\
84-0657.1 \\
81-0477 \\
88-0045.1 \\
84-0026 \\
84-0184 \mathrm{C}\end{array}$ & $\begin{array}{r}139.1 \\
111.4 \\
49.4 \\
10.0 \\
16.1 \\
23.9 \\
17.0 \\
6.7 \\
7.5 \\
5.8 \\
19.7\end{array}$ & $\begin{array}{l}3.92 \\
4.75 \\
2.63 \\
1.00 \\
3.98 \\
0.33 \\
0.35 \\
3.13 \\
1.20 \\
6.55 \\
1.98\end{array}$ & $\begin{array}{l}5.03 \\
5.03 \\
3.24 \\
3.00 \\
4.97 \\
0.67 \\
0.65 \\
3.58 \\
1.47 \\
6.90 \\
2.03\end{array}$ & $\begin{array}{r}28.48 \\
5.98 \\
23.18 \\
200.08 \\
25.08 \\
100.08 \\
83.38 \\
14.38 \\
22.28 \\
5.38 \\
2.68\end{array}$ \\
\hline
\end{tabular}

of 11 approved projects that use PDCs, 3 obtain bonuses of 83 to 2008,3 obtain bonuses of 23 to $28.48,1$ obtains 14.38 , and 3 obtain $2 . \overline{6}$ to 5.98 .

3 projects obtained density increases of more than 50\%. All of these were in zones with base densities less than $1 \mathrm{du} / \mathrm{ac}$.

Two projects with base densities of 3.92 and 3.98 utilized density increases of 28.48 and 25.08 respectively, reaching final gross densities of 5.03 and 4.97 .

For projects that utilize PDCs, substantial density increases have been obtained. In only 3 of 11 projects would it be 
accurate to characterize. the bonus units obtained as marginal in nature.

The greatest percentage increases were obtained where the base density was the lowest. However, at least two major projects obtained increases of more than 258 where the base density was nearly $4 \mathrm{du} / \mathrm{ac}$.

\section{K. DENSITY RANGES WHERE PDC BONUSES MAY BE EXERCISED}

Information by municipal zone on vacant land and base and PDC densities was manipulated to produce a table showing, for each zone, the number of PDC bonus units that could be achieved in various density ranges. Table 21 summarizes this data, and Table 22 presents it in detail. It should be noted that if a particular zone permits a base density of 2 du/acre to increase to $5 \mathrm{du} / \mathrm{acre}$, it could permit 100 bonus units in the $2-3 \mathrm{du} / \mathrm{ac}$ range, 100 units in the $3-4$ du/ac range, and 100 units in the $4-5$
du/ac range. To achieve the maximum density, it would be necessary to build all 300 bonus units plus the 200 base units at:a density of $5 \mathrm{du} / \mathrm{acre}$. With that caveat, the following table presents a snapshot of the density ranges in which PDC bonuses now exist.

Table 21. PDC Bonus Units by Density Range

\begin{tabular}{|c|c|c|c|c|}
\hline \multicolumn{3}{|c|}{ Density } & $\begin{array}{r}\text { Number } \\
\text { of } \\
\text { Units }\end{array}$ & $\begin{array}{r}\text { Percent } \\
\text { of } \\
\text { Units }\end{array}$ \\
\hline $\begin{array}{l}0 \\
1 \\
2 \\
3 \\
4 \\
5 \\
6 \\
-7 \\
8\end{array}$ & $\begin{array}{l}\text { to } \\
\text { to } \\
\text { to } \\
\text { to } \\
\text { to } \\
\text { to } \\
\text { to } \\
\text { to } \\
\text { to }\end{array}$ & $\begin{array}{l}1 \\
2 \\
3 \\
4 \\
5 \\
6 \\
7 \\
8 \\
9\end{array}$ & $\begin{array}{r}905 \\
9,490 \\
4,650 \\
3,461 \\
4,435 \\
6,190 \\
4,754 \\
2,219 \\
55\end{array}$ & $\begin{array}{r}2.58 \\
26.28 \\
12.98 \\
9.68 \\
12.38 \\
17.18 \\
13.18 \\
6.18 \\
0.28\end{array}$ \\
\hline & & & 36,159 & 100.08 \\
\hline
\end{tabular}

Roughly half (498) of PDC opportunities in present zoning can only be achieved at densities greater than $4 \mathrm{du} / \mathrm{ac}$.

198 of PDC opportunities can only be achieved at densities of 6 units per acre or more. 
428 of PDC opportunities can be achieved at densities of less than $3 \mathrm{du} / \mathrm{ac}$.

PDC bonuses are spread over a wide range of densities. If densities above $4 \mathrm{du} / \mathrm{ac}$ are viewed as less likely to be utilized, the accessible supply of PDC redemption opportunities is less than it may appear at first glance. 
Table 22: PDC Bonuses by Density Range (continued)

\begin{tabular}{|c|c|c|c|c|c|c|c|c|c|}
\hline & & & & Der & ange & & & & \\
\hline Zone & $0-1$ & $1-2$ & $2-3$ & $3-4$ & $4-5$ & $5-6$ & $6-7$ & $7-8$ & $8-9$ \\
\hline RG-1 & $\rho$ & 0 & 248 & 0 & 0 & 0 & 0 & 0 & 0 \\
\hline $\begin{array}{l}\text { RG-2 } \\
\text { RG-3 }\end{array}$ & & $\begin{array}{r}173 \\
0\end{array}$ & & $\begin{array}{r}0 \\
72\end{array}$ & $\begin{array}{l}0 \\
0\end{array}$ & $\begin{array}{l}0 \\
0\end{array}$ & $\begin{array}{l}0 \\
0\end{array}$ & $\begin{array}{l}0 \\
0\end{array}$ & $\begin{array}{l}0 \\
0\end{array}$ \\
\hline RG-4 & 0 & 0 & 20 & 0 & 0 & 0 & 0 & 0 & 0 \\
\hline & 0 & 173 & 409 & 72 & 0 & 0 & 0 & $\mathbf{0}$ & 0 \\
\hline * Municipality & Galloway & & & & & & & & \\
\hline $\begin{array}{l}\text { PIRD } \\
\text { R-PUD }\end{array}$ & $\begin{array}{l}0 \\
0\end{array}$ & $\begin{array}{r}158 \\
0\end{array}$ & $\begin{array}{r}317 \\
0\end{array}$ & $\begin{array}{r}317 \\
0\end{array}$ & $\begin{array}{r}317 \\
0\end{array}$ & $\begin{array}{r}317 \\
0\end{array}$ & $\begin{array}{r}317 \\
0\end{array}$ & $\begin{array}{l}317 \\
110\end{array}$ & $\begin{array}{r}0 \\
55\end{array}$ \\
\hline & 0 & 158 & 317 & 317 & 317 & 317 & 317 & 427 & 55 \\
\hline
\end{tabular}

$\underset{\infty}{\omega}$

$\begin{array}{lc}\star \text { Municipality Hamilton } \\ \text { GA-L } & 0 \\ \text { GAM } & 0 \\ \text { GAM-PURD } & 0 \\ \text { GAI } & 0 \\ \text { GAI-PURD } & 0 \\ \star \star \text { SUBTOTAL } \star \star & \end{array}$

325
304
0
516
0
1145

$\mathbf{0}$
$\mathbf{0}$
$\mathbf{0}$
$\mathbf{0}$
$\mathbf{0}$

$\mathbf{0}$
$\mathbf{0}$
$\mathbf{0}$
$\mathbf{0}$
$\mathbf{0}$
$\mathbf{0}$

0
0
555
0
394
949

0
0
277
0
1577
1854

$\begin{array}{rr}0 & 0 \\ 0 & 0 \\ 0 & 0 \\ 0 & 0 \\ 1577 & 315 \\ 1577 & 315\end{array}$

* Municipality Jackson

RG-1
RG-2
RG-3
RG-4
$\star \star$ SUBTOTAL $\star \star$

0
0
0
0
0

252
0
0
0
252

$\begin{array}{rr}0 & 0 \\ 1052 & 752 \\ 111 & 223 \\ 0 & 0 \\ 1163 & 975\end{array}$

0
0
223
413
636

0
0
223
413
636

0
0
0
413
413

Note: Only zoning districts affording PDC density bonuses have been included in this table. 
Table 22: PDC Bonuses by Density Range (continued)

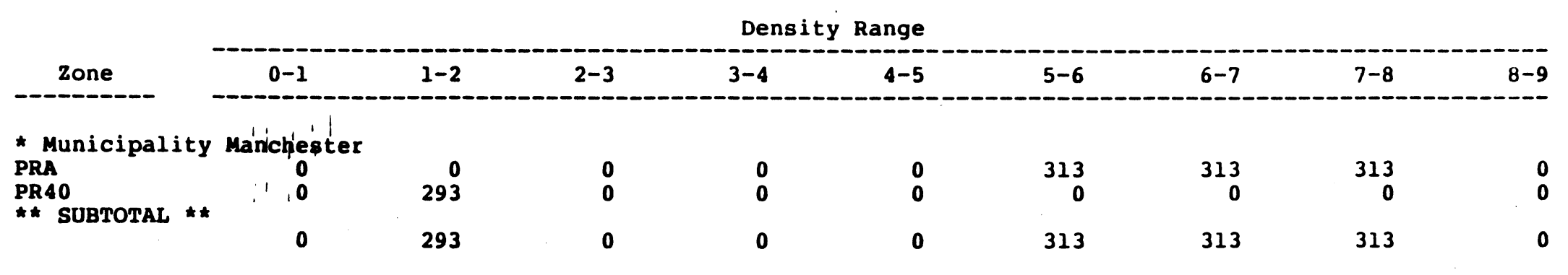

* Municipality Medford

$\begin{array}{lccc}\star \text { GMS } & 0 & 399 & 133 \\ \text { GD } & 0 & 469 & 125 \\ \star \star \text { SUBTOTAL } \star \star & 0 & 868 & 258\end{array}$

$\omega_{0} \quad$ all Municipality Medford Lakes

$\begin{array}{cc}\text { all.. } & 0 \\ \star \star \text { SUBTOTAL * } & 0\end{array}$

$\begin{array}{ll}0 & 0 \\ 0 & 0\end{array}$

$\begin{array}{ll}0 & 0 \\ 0 & 0 \\ 0 & 0\end{array}$

$\mathbf{0}$
$\mathbf{0}$
0

$\begin{array}{lll}0 & 0 & 0 \\ 0 & 0 & 0 \\ 0 & 0 & 0\end{array}$

* Municipality Monroe

$\begin{array}{lrrrrr}\star \text { Municipality } & \text { Monroe } & & & \\ \text { RG-MR } & 0 & 856 & 285 & 0 & 0 \\ \text { RG-20 } & 0 & 321 & 107 & 0 & 0 \\ \text { RG-PR(PRD) } & 0 & 0 & 0 & 0 & 500 \\ \text { RG-PR } & 0 & 1499 & 499 & 0 & 0 \\ \star \star \text { SUBTOTAL * } & & & & & 500\end{array}$

Note: Only zoning districts affording PDC density bonuses have been 
Table 22: PDC Bonuses by Density Range (continued)

Density Range

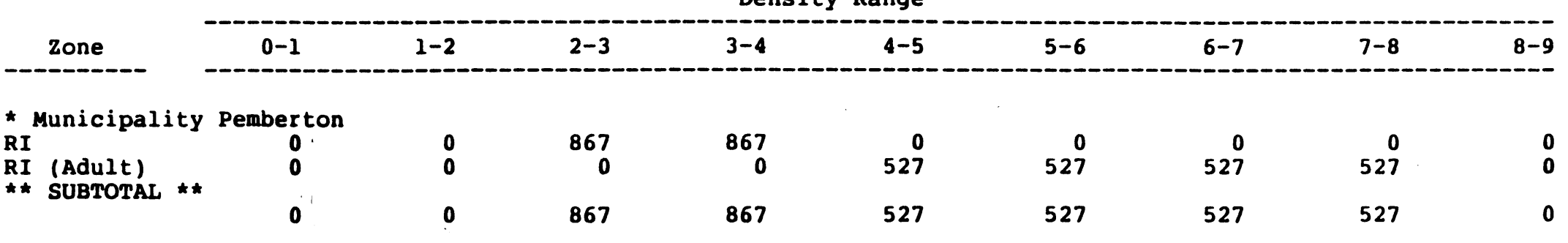

* Municipality Southhampton

* * SUBTOTAL **

307
307

* Municipality stafford

$R-90$ (PDC) 0

o

0

0

527

527

527

0

$\star \star$ SUBTOTAL *

0

0

0
0

0
0

8
8

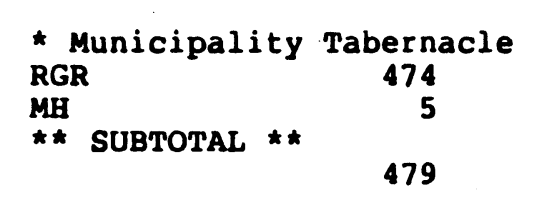

$\begin{array}{lc}\star \text { Municipality } & \text { Waterford } \\ \text { R-3 } & 0 \\ \text { R-4 } & 0 \\ \text { RG } & 0 \\ \star \star \text { SUBTOTAL } \star \star & \end{array}$ Note: Only zoning districts affording PDC density bonuses have been
included in this table.

0
0
0

$\begin{array}{ll}0 & 0 \\ 0 & 0 \\ 0 & 0\end{array}$

$\mathbf{0}$
$\mathbf{0}$

$\begin{array}{llll}43 & 34 & 0 & 0 \\ 43 & 34 & 0 & 0\end{array}$


Table 22: PDC Bonuses by Density Range (continued)

Density Range

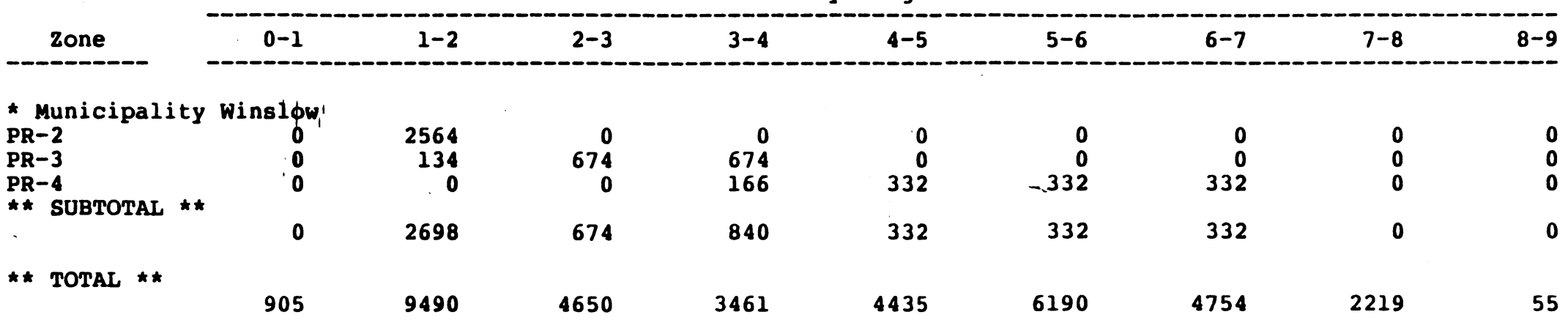




\section{ZONING STANDARDS ANALYSIS}

Bulk standards and other requirements may interfere with achievement of stated PDC densities. Some bulk standards clearly are appropriate for base densities, but not for PDC densities, and some ordinances may not include explicit standards for PDC development.

To determine if unworkable development standards exist in municipal ordinances, 14 different zoning schemes in 5 municipalities were analyzed. A summary of the analysis is presented in Table 23 .

Of the 14 different zoning districts that were analyzed, 9 worked and 5 did not work

of the 5 that did not work:

o 4 were for single family detached orly zones. In three of these four, the constraining factors were bulk regulation governing lot width and depth which were not changed to reflect the smaller lots otherwise permitted when PDCs are used.

- In the fourth, the minimum lot area was equivalent to the assigned density and thus does not account for roads, etc.

- The fifth zone permits both single family detached and attached units, the minimum lot areas of which are slightly larger than the density would require.

of the 9 that worked:

- 8 permitted a variety of dwelling types at densities ranging from 4.0 to $8.5 \mathrm{du} / \mathrm{ac}$.

- I permitted both attached and detached housing at a density of $2.25 \mathrm{du} / \mathrm{ac}$.

o In the eight higher density districts, the density is achievable if a mix of housing types is permitted. The percentage of single family detached housing on smaller lots $(5,000$ to $8,000 \mathrm{sq} \mathrm{ft.})$ varies from 108 to 638 .

o In the lower density district, the density would permit all single family detached. 
Table 23. Summary of Zoning Standards Analysis

\begin{tabular}{|c|c|c|c|c|c|}
\hline Mun & Zone & $\begin{array}{r}\text { Max } \\
\text { Density } \\
\text { du/ac }\end{array}$ & $\begin{array}{l}\text { Hous- } \\
\text { ing } \\
\text { Types }\end{array}$ & $\begin{array}{r}\text { Density } \\
\text { Achiev- } \\
\text { able? }\end{array}$ & Note \\
\hline Galloway & $\begin{array}{l}\text { R (PURD) } \\
\text { PIRD }\end{array}$ & $\begin{array}{l}8.5 \\
8.0\end{array}$ & $\begin{array}{l}\text { Al1 } \\
\text { All }\end{array}$ & $\begin{array}{l}Y \\
Y\end{array}$ & \\
\hline Pemberton & $\begin{array}{l}R-I \\
R-I \text { (Age) }\end{array}$ & $\begin{array}{l}4.0 \\
8.0\end{array}$ & $\begin{array}{l}\text { All } \\
\text { All }\end{array}$ & $\begin{array}{l}Y \\
Y\end{array}$ & $\begin{array}{l}1 \\
2\end{array}$ \\
\hline Barnegat & $\begin{array}{l}R-45 \\
R-45(C) \\
R-45(P A C) \\
R-9\end{array}$ & $\begin{array}{l}1.7 \\
6.0\end{array}$ & $\begin{array}{r}\text { SFD } \\
\text { SFD } \\
\text { SFD, SFA, TH } \\
\text { SFD }\end{array}$ & $\begin{array}{l}\mathbf{N} \\
\mathrm{N} \\
\mathbf{Y} \\
\mathrm{N}\end{array}$ & $\begin{array}{l}3 \\
4 \\
5 \\
6\end{array}$ \\
\hline Winslow & $\begin{array}{l}\text { PR-2 } \\
P R-3 \\
P R-4 \\
P R-4 \text { (PUD) }\end{array}$ & $\begin{array}{l}2.0 \\
4.0 \\
7.0 \\
7.0\end{array}$ & $\begin{array}{l}\text { SFD } \\
\text { SFD } \\
\text { SFA } \\
\text { All } \\
\text { All }\end{array}$ & $\begin{array}{l}\mathbf{N} \\
\mathbf{N}\end{array}$ & $\begin{array}{l}7 \\
8\end{array}$ \\
\hline Monroe & $\begin{array}{l}\text { RG-MR } \\
\text { RG-PR } \\
\text { RG-PR }\end{array}$ & $\begin{array}{r}2.25 \\
2.25 \\
7.4\end{array}$ & $\begin{array}{l}\text { SFD } \\
\text { SFA } \\
\text { SFD } \\
\text { SFA } \\
\text { All }\end{array}$ & $\begin{array}{l}Y \\
Y \\
Y \\
Y \\
Y\end{array}$ & 10 \\
\hline
\end{tabular}

Notes :

1 SFD does not meet the density by itself. Approximately $37 \%$ of units would have to be SFA, TH, APR

2 Requires the following mix: 258 SFD $5,000 \mathrm{sq} f t$ $358 \mathrm{TH} 3,950 \mathrm{sq} \mathrm{ft}$ 40 Apts $3,600 \mathrm{sq} \mathrm{ft}$

3 Bulk regs were not changed to reflect smaller lot areas for PDC use.

4 Minimum lot area of $15,000 \mathrm{sq}$ ft needed to satisfy density and open space standards. 
Table 23. Summary of Zoning Standards Analysis (continued)

Notes (continued):

5 Requires the following mix:

638 SFD $5,000 \mathrm{sq} f t$

$278 \mathrm{TH} 1,500 \mathrm{sq} f t$

6 Bulk regs were not changed to reflect smaller lot areas for PDC use.

7 Requires a lot area of $17,500 \mathrm{sq} \mathrm{ft}$.

8 SFD needs minimum lot of 7,500 and SFA needs minimum lot of 8,000 for this to work

9. Requires a mix of housing types. SFD probably could not exceed 558 with 148 two family and 318 townhouses.

10 Requires the following mix:

108 SFD \& SFA with $8,000 \& 7,000$ sq $\mathrm{ft}$ lots $608 \mathrm{TH}$

308 Apts 


\section{WETLANDS AND BUFFERS IN APPROVED PROJECTS}

The existence of wetlands and wetland buffers can have a dramatic effect on the net density of a residential project. To judge whether or not these net densities are substantially higher than permitted gross densities and have a limiting effect on the real potential for PDC use, a sample of 27 projects was analyzed. Wetlands and buffers expressed as acreages and as percent of total site area are shown in Table 24 . Gross densities on total site area, upland area, and non-buffer upland area area shown in Table 25, along with the maximum density that the zoning ordinance would permit on each category of land.

The analysis disclosed that wetlands and wetland buffers would increase the actual net densities of 13 (or 488 ) of the 27 projects. Seven (or 26\%) were affected such that net densities were half again higher than gross densities and four of those would require that net densities exceed 16 du/acres.

Although it doesn't appear that wetlands and associated buffers are a significant constraint to PDC use, it must also be recognized that assigned gross densities will be effectively increased in half or more of all instances. To the extent that gross densities exhibit borderline use of PDCs, the existence of wetlands and associated buffers could have the net effect of negating their use. 
Table 24. Approved Projects: Wetlands and Buffers

\begin{tabular}{|c|c|c|c|c|c|c|}
\hline FileNo & $\begin{array}{l}\text { Wet- } \\
\text { land } \\
\text { Acres }\end{array}$ & $\begin{array}{l}\text { Upland } \\
\text { Buffer } \\
\text { Acres }\end{array}$ & $\begin{array}{r}\text { Upland } \\
\text { Not } \\
\text { Buffer } \\
\text { Acres }\end{array}$ & $\begin{array}{l}\text { Total } \\
\text { Acres }\end{array}$ & $\begin{array}{r}q \\
\text { Wet }\end{array}$ & Buffer \\
\hline $\begin{array}{l}81-0202 A \\
81-0437 \\
81-0477 \\
81-0491 \\
81-0545 \\
81-0560 \\
81-0852 \\
81-0949 \\
81-1028 \\
81-1517.2 \\
81-2305 \\
82-2756 \\
82-3172 \\
82-3379 \\
83-9248 \\
83-9693 \\
84-0026 \\
84-0095 \mathrm{C} \\
84-0166.3 \\
84-0184 \mathrm{C} \\
84-0770 \mathrm{C} \\
84-1143.1 \\
85-0820 \\
85-0861 \mathrm{C} \\
85-0906 \\
85-1239.2 \\
86-0703\end{array}$ & $\begin{array}{r}378.0 \\
2.6 \\
0.0 \\
0.0 \\
131.5 \\
0.0 \\
2.4 \\
0.0 \\
2.0 \\
3.9 \\
3.3 \\
0.0 \\
0.0 \\
0.0 \\
5.5 \\
0.0 \\
0.4 \\
0.0 \\
5.2 \\
5.3 \\
2.6 \\
0.7 \\
0.0 \\
0.0 \\
0.0 \\
0.0 \\
21.9\end{array}$ & $\begin{array}{r}79.7 \\
2.6 \\
0.0 \\
0.0 \\
140.0 \\
0.0 \\
5.6 \\
0.0 \\
6.9 \\
6.0 \\
7.1 \\
0.0 \\
0.0 \\
0.0 \\
5.5 \\
0.0 \\
1.3 \\
0.0 \\
1.0 \\
4.8 \\
5.6 \\
32.2 \\
0.0 \\
2.4 \\
0.0 \\
0.0 \\
7.2\end{array}$ & $\begin{array}{r}83.7 \\
6.2 \\
6.7 \\
66.6 \\
72.4 \\
72.0 \\
103.4 \\
13.1 \\
14.4 \\
49.2 \\
9.7 \\
108.5 \\
68.0 \\
5.7 \\
5.1 \\
17.1 \\
4.1 \\
111.4 \\
3.5 \\
9.6 \\
15.5 \\
130.9 \\
33.1 \\
21.4 \\
4.7 \\
45.0 \\
17.0\end{array}$ & $\begin{array}{r}541.4 \\
11.4 \\
6.7 \\
66.6 \\
343.9 \\
72.0 \\
111.4 \\
13.1 \\
23.3 \\
59.1 \\
20.1 \\
108.5 \\
68.0 \\
5.7 \\
16.1 \\
17.1 \\
5.8 \\
111.4 \\
9.7 \\
19.7 \\
23.7 \\
163.8 \\
33.1 \\
23.8 \\
4.7 \\
45.0 \\
46.1\end{array}$ & $\begin{array}{r}69.88 \\
22.88 \\
0.08 \\
0.08 \\
38.28 \\
0.08 \\
2.28 \\
0.08 \\
8.68 \\
6.68 \\
16.38 \\
0.08 \\
0.08 \\
0.08 \\
34.28 \\
0.08 \\
6.98 \\
0.08 \\
53.68 \\
27.08 \\
11.08 \\
0.48 \\
0.08 \\
0.28 \\
0.08 \\
0.08 \\
47.58\end{array}$ & $\begin{array}{r}14.78 \\
22.88 \\
0.08 \\
0.08 \\
40.78 \\
0.08 \\
5.08 \\
0.08 \\
29.68 \\
10.28 \\
35.68 \\
0.08 \\
0.08 \\
0.08 \\
34.28 \\
0.08 \\
22.48 \\
0.08 \\
10.38 \\
24.48 \\
23.68 \\
19.78 \\
0.08 \\
10.28 \\
0.08 \\
0.08 \\
15.78\end{array}$ \\
\hline Total & 565.3 & 308.0 & $1,097.8$ & $1,971.1$ & $28.7 \%$ & 15.68 \\
\hline
\end{tabular}


Table 25. Actual and Permitted Densities in Approved Projects

\begin{tabular}{|c|c|c|c|c|c|c|}
\hline FileNo & $\begin{array}{r}\text { Actual } \\
\text { Density } \\
\text { on } \\
\text { Total }\end{array}$ & $\begin{array}{r}\text { Actual } \\
\text { Density } \\
\text { on } \\
\text { Upland }\end{array}$ & $\begin{array}{r}\text { Actual } \\
\text { Density } \\
\text { on } \\
\text { Non-buff } \\
\text { Upland }\end{array}$ & $\begin{array}{r}\text { Permitted } \\
\text { Density } \\
\text { on } \\
\text { Total }\end{array}$ & $\begin{array}{r}\text { Permitted } \\
\text { Density } \\
\text { on } \\
\text { Upland }\end{array}$ & $\begin{array}{r}\text { Permitted } \\
\text { Density } \\
\text { on } \\
\text { Non-buff } \\
\text { Upland }\end{array}$ \\
\hline $\begin{array}{l}81-0202 A \\
81-0437 \\
81-0477 \\
81-0491 \\
81-0545 \\
81-0560 \\
81-0852 \\
81-0949 \\
81-1028 \\
81-1517.2 \\
81-2305 \\
82-2756 \\
82-3172 \\
82-3379 \\
83-9248 \\
83-9693 \\
84-0026 \\
84-0095 \mathrm{C} \\
84-0166.3 \\
84-0184 \mathrm{C} \\
84-0770 \mathrm{C} \\
84-1143.1 \\
85-0820 \\
85-0861 \mathrm{C} \\
85-0906 \\
85-1239.2 \\
86-0703\end{array}$ & $\begin{array}{l}0.97 \\
1.14 \\
3.58 \\
3.30 \\
2.22 \\
0.33 \\
5.03 \\
1.75 \\
0.56 \\
0.51 \\
3.99 \\
3.49 \\
2.51 \\
3.84 \\
4.97 \\
1.41 \\
8.28 \\
0.74 \\
1.03 \\
2.03 \\
0.89 \\
0.15 \\
0.54 \\
0.59 \\
3.86 \\
0.69 \\
3.58\end{array}$ & $\begin{array}{l}3.22 \\
1.48 \\
3.58 \\
3.30 \\
3.60 \\
0.33 \\
5.14 \\
1.75 \\
0.61 \\
0.54 \\
4.76 \\
3.49 \\
2.51 \\
3.84 \\
7.55 \\
1.41 \\
8.89 \\
0.74 \\
2.22 \\
2.79 \\
1.00 \\
0.15 \\
0.54 \\
0.59 \\
3.86 \\
0.69 \\
6.81\end{array}$ & $\begin{array}{r}6.28 \\
2.10 \\
3.58 \\
3.30 \\
10.55 \\
0.33 \\
5.42 \\
1.75 \\
0.90 \\
0.61 \\
8.29 \\
3.49 \\
2.51 \\
3.84 \\
15.72 \\
1.41 \\
11.71 \\
0.74 \\
2.86 \\
4.18 \\
1.36 \\
0.18 \\
0.54 \\
0.66 \\
3.86 \\
0.69 \\
9.70\end{array}$ & $\begin{array}{l}2.17 \\
2.20 \\
3.00 \\
7.20 \\
3.40 \\
1.00 \\
7.04 \\
2.25 \\
0.60 \\
0.60 \\
8.00 \\
6.00 \\
5.25 \\
7.00 \\
8.00 \\
2.00 \\
2.25 \\
0.31 \\
2.25 \\
4.00 \\
2.20 \\
1.00 \\
1.80 \\
0.60 \\
4.50 \\
1.50 \\
8.00\end{array}$ & $\begin{array}{r}7.20 \\
2.85 \\
3.00 \\
7.20 \\
5.50 \\
1.00 \\
7.20 \\
2.25 \\
0.66 \\
0.64 \\
9.56 \\
6.00 \\
5.25 \\
7.00 \\
12.15 \\
2.00 \\
2.42 \\
0.31 \\
4.85 \\
5.48 \\
2.47 \\
1.00 \\
1.80 \\
0.60 \\
4.50 \\
1.50 \\
15.22\end{array}$ & $\begin{array}{r}14.06 \\
4.05 \\
3.00 \\
7.20 \\
16.14 \\
1.00 \\
7.59 \\
2.25 \\
0.97 \\
0.72 \\
16.64 \\
6.00 \\
5.25 \\
7.00 \\
25.29 \\
2.00 \\
3.18 \\
0.31 \\
6.24 \\
8.23 \\
3.37 \\
1.25 \\
1.80 \\
0.67 \\
4.50 \\
1.50 \\
21.70\end{array}$ \\
\hline
\end{tabular}


N. POPULATION AND HOUSHHOLD PROJECTIONS

Table 26. Population and Household Increase Expected in RGA Counties

\begin{tabular}{lcrrr} 
& Est & Proj & $\begin{array}{r}\text { Pop } \\
\text { Increase }\end{array}$ & $\begin{array}{r}\text { HH } \\
\text { Increase }\end{array}$ \\
& 1984 & 2000 & $84-100$ & $84-100$ \\
\hline Atlantic & 200,900 & 260,100 & 59,200 & 21,899 \\
Burlington & 377,700 & 467,200 & 89,500 & 28,363 \\
Camden & 485,100 & 577,200 & 92,100 & 31,733 \\
Gloucester & 205,600 & 249,100 & 43,500 & 14,171 \\
Ocean & 371,300 & 484,400 & 113,100 & 41,935 \\
\hline$-90 t a l$ RGA Counties & $1,640,600$ & $2,038,000$ & 397,400 & 138,101
\end{tabular}

Note: Population Estimates and Projections by NJDL/ODEA, projected household increase derived.

Population of the 5 counties with Pinelands RGAs is projected by New Jersey Department of Labor to increase by 397,400 in -16 years. This population increase will result in the formation of an estimated 138,101 households. Housing stock in the five county area would be expected to increase by at least that number of units, plus some additional units to replace demolished units and some units to account for vacancies that normally exist. This would suggest that a vigorous housing market should exist to support the operation of the PDC program.

\section{O. LESSONS FROM OTHER TDR PROGRAMS}

\section{1) Montgomery County, Maryland}

In the Montgomery County, Maryland program, 1 TDR was allocated per 5 acres of sending land, and was worth 1 bonus unit in the receiving area. (This is nearly equivalent to the PDC allocation-in -agricultural areas where 39 acres yields 2 PDCs which, in turn, yield 8 bonus units.) The price per TDR ranges from $\$ 3,500$ to $\$ 8,000.2,300$ credits have been approved, and 1,100 more are pending.

In Montgomery County's TDR program, the following factors were identified as being important to program success:

- Strong development demand (location near metro Washington D.C.); 
- Early staff effort to promote program;

- Targeting of improvements such as sewers to TDR receiving areas.

\section{$0.2)$ Calvert County, Maryland}

In Calvert County, Maryland, with a similar program, 5 acres yields one bonus unit (each acre receives a credit but 5 credits are needed for each residential unit to be built). Credits yielding 600 bonus units have been transferred at prices ranging between $\$ 6,000$ and $\$ 10,000$ per bonus unit.

Factors believed to contribute to success in Calvert County are:

o Strong demand in receiving areas (adjacent to Washington, D.C.);

o. Early staff effort to promote the program resulted in support from farmers and developers.

\section{3) Collier County, Florida}

In Collier County, Florida, only one transfer has taken place. Identified problems include:
- The ability of developers to cluster density from undevelopable land onto developable land;
o high base densities (in the 'teens);
o Resistance to higher density development by the County.

\section{4) San Luis Obispo, California}

A program in San Luis Obispo, California was initiated in 1986 with the goal of preserving steep mountain slopes from development-. -The preservation area consists of approximately 40 acres of steep slope subdivided into very small lots. The program is based on the transfer of floor area. Buildable lots in the preservation area yield a credit worth $600 \mathrm{sq} f t$ of floor area. In the receiving area, the maximum floor area permitted is $1000 \mathrm{sq} f t$ unless TDR credits are purchased. The San Luis Obispo County Land Conservancy purchases and sells all credits; there is no private market. Approximately 30 credits, or 18,000 sq $f t$ of floor space have been transferred. 


\section{5) Santa Monica Mountains, California}

In the Santa Monica Mountains, in California a TDR program was initiated in 1979 with the goal of preserving steep slopes from development. The slopes, which have a view of the ocean, were subdivided into small lots, many of which are considered to be unbuildable due to size, slope, lack of access and natural hazards. There are no sending and receiving areas designated, only an area within which credits may be transferred. Any lot considered buildable for a house of $1,500 \mathrm{sq}$ ft earns a credit. Any lot greater than $4,000 \mathrm{sq} \mathrm{ft}$, whether buildable or not, earns $1 / 3$ credit. Any lot, regardless of size, in a "Significant Ecological Area" earns 1 credit.

One credit earns one additional dwelling unit in the receiving area; no new subdivision may take place without use of credits. Demand for credits is strong, but credits are in short supply.

Approximately 250 credit have been transferred, and the current price of a credit is approximately $\$ 17,000$. Transfers must be approved by the California Coastal Commission. There is a private market in credits, but the California Coastal Conservancy acts as a broker.

\section{5) Buckingham Township, Pennsylvania}

A TDR program in Buckingham Township, Pa., enacted in 1975, allocated 1 credit per 10 acres in a 13,000 preservation area. Each credit permits one added unit in a 5,000 acre receiving area. A total of 30 credits have been transferred, of which only 3 were in the last 8 years. Current value of a credit is estimated at $\$ 5,000$. The relative lack of interest in the program is attributed to absence of sewers in the receiving area and a high demand for large lot residential development. 


\section{P. USES EORGONE ON SALE OF PDCS}

The value of currently permitted uses may compete with PDCs as viable options for landowners to gain financially from their land. Among these uses, which would be forgone if PDCs were severed from the land, are:

Table 27. Land Uses Forgone Upon Sale of PDCs

Management

Area

Land Uses Forgone

Ag Production Cultural housing

Limited non-farm housing

Roadside retail

Pinelands resource industry

Expansion of existing intensive recreation

Preservation Cultural housing

Expansion of intensive recreation

Campgrounds

Continued resource extraction

Special Ag

Cultural housing

Agriculture-related housing

This could reduce the number of PDCs offered for sale, or require a higher price for a sale to take place.

\section{Q. PINELANDS INFRASTRUCTURE TRUST SEWER PROJECTS}

Sewer service is needed for development at PDC densities in most municipal zoning ordinances. Substantial areas of Regional Growth Area do not now have sewer service available, however the Pinelands Infrastructure Trust (PIT) provides a funding mechanism to underwrite construction projects. Some $\$ 30$ million have been appropriated by the legislature for funding of 9 projects. - While each of these projects is important, the progress made-by the sponsors in obtaining needed approvals varies from project to project.

The Harding Highway project in Hamilton will enable planned projects to connect to a sewer; indeed project planning in Hamilton has long reflected the anticipation of sewer service. At present the Hamilton sewage treatment plant is subject to a connection ban due to water quality discharge problems. The resolution to this problem is the construction of the Atlantic County Utilities Authority's Coastal Interceptor, which is also eligible for Pinelands Infrastructure Trust funding. The 
Coastal Interceptor has been delayed for some time by various litigation and negotiation regarding the apportionment of capital costs. In addition, Atlantic County has not, at this writing, achieved conformance, and the Coastal Interceptor cannot, pursuant to the authorizing legislation, be funded until the county has achieved conformance.

Egg Harbor Township, not yet in conformance, has provided sewers to only a small portion of its growth area. The EHT MUA claims that it is capable of providing service as needed, but their policy, informally stated, has been to require developers to pay the full cost of providing needed services to new development.

The Monroe RGA will be served by a PIT construction project, and there seems to be no impediment to progress of that project.

Sewer service issues in lower Camden County are still in the process of being resolved, so it is likely that Winslow, Chesilhurst and Waterford RGAs will be subject to some delay.

Jackson and Manchester are potentially important RGAs for the PDC program. The OCUA has made no progress on the Ridgeway Cabin Branch project, funded by the PIT. In the absence of that sewer, the Jackson and Manchester RGAs appear to be developing at densities allowed by on site sewage disposal. This low density development will no doubt pre-empt PDC redemption opportunities.

While the major impediment to progress on PIT sewer projects to date has been preparation of necessary reports by project sponsors, and review of those reports by DEP, it should be noted that the Tax Reform Act of 1986 has called into question the tax exempt status of state issued bonds for the Trust. It appears, at the time of this writing, that the PIT in general will be eligible for tax exempt funding. Private involvement in each project will be reviewed by the Department of the Treasury, and it is possible that some projects may not meet the criteria for tax exempt status. 


\section{CONCLUSIONS}

\section{A. STATUS OF THE PDC PROGRAM}

A.1) The PDC program is operational and must at the very least be considered moderately successful. Burlington County's purchase of 90.75 PDCs, its resale of 41 PDCs, and the existence of 21 built, approved, and active projects involving the use of 166.75 PDCs are clearly indicative of a working program. It is also noteworthy that PDC purchases by developers are showing a marked increase, up from 2.25 in 1984 to 21.50 through eight months of 1988 .

A.2) The experience of the New Jersey PDC Bank during its first months of operation is also encouraging. The Bank's Acting Executive Director reports 40 inquiries from property owners interested in selling PDCs and 25 inquiries from developers interested in PDC purchase.

A.3) Nevertheless, the rate at which PDCs are being used in relation to the total amount of development taking place is less encouraging.

Of the 51 projects surveyed, 11 (or 22\%) involved the use of PDCs. PDC units accounted for 3.58 of the total number of units approved. Detailed evaluation of permitted and actual densities of 27 of those projects indicated that roughly 518 of maximum permitted development capacities were not utilized.

If these trends were to continue, one might postulate that actual development in Regional Growth Areas will approach 54,300 units (498 of total zone capacities), of which 1,900 will be PDC bonus units.

Although such a projection is pure conjecture at this point and ignores some of the more recent development trends and increâsing purchases of PDCs, it is difficult to anticipate an extremely high rate of PDC use if past development conditions continue.

A.4) Even at a lower rate of PDC use, there is not an overabundance of PDCs on the market. Burlington county has the highest percentage of all PDCs available for allocation yet it has not been approached by large numbers of property owners wishing to sell their PDCs. Moreover, the total number of PDCs actually allocated through Letters of 
Interpretation is modest. It can be argued that a lower rate of PDC use in growth areas is not problematic if it is sufficient to accommodate those PDCs which property owners wish to place on the market. If indeed the program accommodates interested property owners and developers, even though the raw number of participants is less than expected, it is a success. However, it is not possible at this point to state that property owner interest in the program would remain stable if the demand for PDC use or the PDC purchase price were to increase.

B. SUITABILITY OF REGIONAL GROWTH AREAS FOR DEVELOPMENT

B.1) Regional Growth Areas are suitable for the type of residential development envisioned under the pinelands Plan. Although the existence of Pinelands land use and development controls may serve to deflect a portion of development outside of the region, there is still

substantial interest in RGA development as illustrated by the project analysis undertaken as part of this evaluation.

The intensity at which that development may occur is open to some question as evidenced by the fact that many of the RGA projects are being developed at lower than maximum permitted densities. Although housing market information suggests that higher density development (townhouses and condominiums/apartments) is indeed marketable, it is not dominating the market.

B.2) Adequate lands remain available for development in RGAs. The 51 largest residential projects consumed 4,102 acres or roughly $10 \%$ of the total estimated amount of vacant land in RGAs. Obviously, this percentage is conservative since it does not account for all of the large projects nor does it reflect land consumed for much smaller developments. However, there is still ample land remaining in the RGAs.

B.3.) Zoning schemes should be structured such that density assignments in highly fragmented and already subdivided areas match tenure patterns. Land tenure (i.e. size of parcels held in common ownership) patterns were not quantifiably analyzed in this evaluation; however, an assessment of mapped tax information does suggest that sites greater than 30 acres in size are in ample supply. Moreover, parcel size itself does not seem to be an overly constraining factor in that, of the 51 projects surveyed: roughly $50 \%$ involved tracts less than 30 acres in size; the 
density of development on the larger tracts was not substantially different than that of the smaller tracts; and $73 \%$ of the PDC projects involved tracts less than 24 acres in size.

On the other hand, where land tenure patterns are such that extremely fragmented ownership of small lots (e.g. an acre or less) exist, zoning ordinances must be structured in recognition that those characteristics will not lend themselves to development intensities which vary from that character. For example, it is unrealistic to assume that an already subdivided area of quarter acre lots which are under separate ownership will develop at a density of 6 du/acre.

\section{ECONOMIC AND DENSITY CONSIDERATIONS}

C.1) Development in the Pinelands is occurring at lower densities, yet a disproportionate share of PDC redemption opportunities exist at higher densities. of the 51 projects surveyed, 798 of the residential units are to be built at densities of $4 \mathrm{du} / \mathrm{acre}$ or less. However, only 51.28 of PDC redemption opportunities throughout the Pinelands exist in those density ranges. Regional housing information (Table 7 and Table 15) supports the notion that the vast majority of housing now being built in the region is at lower densities.

Although one may conclude that the lower density zones are being developed at the outset and the higher intensity zones will be developed later, the detailed analysis of 27 projects disclosed that 11 (or 41\%) were located in zones with permitted densities exceeding 4 du/acre.

C.2) PDCs are most valuable when used in projects with densities of 4 du/acre or less. Density increases of 1 du/acre, up to a maximum density of 4 du/acre, result in an estimated PDC value far greater than that projected at higher densities. For example, the- lowest projected value for a PDC in the 4 du/acre or less density range is 1.25 times that of the highest PDC value in the above 4 du/acre range.

PDCs nevertheless have value in higher density zones, particularly when the base density is low, and can offer viable development options where the market supports higher density housing. 
C.3) PDC values may change over time as land becomes more scarce. As land becomes more scarce and competition increases, it is probable that land values will increase as well. Economic as well as market conditions may then yield a much higher per unit value in far higher density development. This potential for higher density development and PDC use should not be foreclosed merely because of current market and economic conditions.

C.4) TDR values in other programs support prices per bonus unit in the range of $\$ 3,500$ to $\$ 17,000$. While the housing markets and economic conditions within which these other programs operate may differ from the conditions in the Pinelands, the fact that prices in that range are supported suggests that PDCs should be marketable in Pinelands Regional Growth Areas.

\section{ZONING STANDARDS AND ACHIEVABLE DENSITY}

D.1) Bulk and other municipal development standards do not generally prevent achievement of assigned densities; however, inadvertent errors in ordinance standards that could impact densities do exist. Five of the 14 zoning schemes analyzed were found to prevent development at permitted densities. In each of these cases, however, the problems appear to be caused by inadvertent errors rather than conscious decisions to circumvent density assignments.

As discussed below, the manner in which ordinances are organized might be a contributing factor.

D.2) Density, bulk, and other ordinance standards governing development at PDC densities are often obscure and difficult to identify.

Many of the ordinances which were reviewed contain PDC related development standards in various sections of the ordinance, oftentimes in sections which an unknowing person may overlook. It is, therefore, probable that persons who are unfamiliar with the PDC program may review a municipal zoning ordinance and not realize that PDCs can be used to increase density. 
D.3) The lack of clarity in ordinances may create perceptions that development at PDC densities is not a matter of right.

Interviews conducted as part of the first stage of the PDC program evaluation suggest that developers and municipal officials may perceive the use of PDCs as a matter of negotiation between the two parties.

To the extent that the ordinances are poorly organized and PDC standards are obscure, this misperception may be perpetuated.

D.4) Similarly, the lack of clarity in the Cup relative to the use of PDCs when density or use variances are granted creates needless uncertainty in the minds of developers and municipal officials. The CMP includes provisions which provide that PDCs may be redeemed as a means to utilize residential density approved by municipal variance. However, the CMP also includes a standard which forgives the use of PDCs when a "fractional" unit is involved. These provisions have been interpreted differently by several developers and municipal officials. For example, it has been suggested that a lot area variance which permits a home to be built on an undersized lot does not require PDC redemption on the theory that the undersized lot would have been entitled to a "fractional" residential unit.

D.5) Due to the novelty of the PDC program and its complexity, municipal officials, developers, and property owners have difficulty understanding its operation. Although both the CMP and municipal zoning ordinances can be clarified, the fact remains that the PDC program is difficult to comprehend. Interviews of municipal officials, developers, and landowners undertaken as the first phase of the program's evaluation confirm that the program suffers from a great many misperceptions. It is also noteworthy that the success of other TDR programs is attributed in part to an aggressive outreach and education program, a feature which has yet to occur in the Pinelands due to funding limitations. 
E. ENVIRONMENTAL STANDARDS AS THEY RELATE TO DEVELOPMENT POTENTIAL

E.1) On a regional basis, wetlands and associated buffers do not significantly constrain development potential. The density of approximately one-half of the projects surveyed was impacted by the existence of wetlands and buffers; however, only five projects were affected such that "net densities" on developable portions of the tracts would exceed 8 du/acre. Significantly constrained parcels are unavoidable and zoning schemes generally should not be based on these exceptional situations. Nevertheless, it is advisable to consider these types of development constraints when preparing land use plans and to consider assigning density for conditional uses (e.g. planned developments) which involve higher densities on the basis of developable rather than gross acreage.

E.2) Lack of centralized wastewater facilities will at least temporarily inhibit the achievement of permitted densities. Absent central wastewater facilities, the density of development will be limited by Pinelands water quality standards. For all intents and purposes, unsewered portions of growth areas can not be developed at a density greater than one unit per acre.

The Pinelands Infrastructure Trust (PIT) provides needed funding for a total of 9 sewer construction projects. These 9 sewer projects, if built, will provide sewer service to a number of important growth areas, and make available a great deal of development potential.

One of these projects has achieved "pre-award approval" for funding. Three other projects have made substantial progress. For the remaining projects, there are either major issues remaining to be resolved, or the project sponsors do not appear to be pursuing the projects.

It must be concluded that the lack of sewer service is a problem to the PDC program, at least in certain areas. The Pinelands Infrastructure Trust program must be viewed as a major constructive approach to the problem. It would be desirable to promote the actual construction of these projects, but the responsibility for action now lies primarily with municipal and county sponsors, and with New Jersey DEP. 


\section{RECOMMENDATIONS}

There is little doubt that the operation of the Pinelands Development Credit program can be improved. As Appendix F suggests, no less than 34 different policy options have been identified through the course of this study. And these by no means represent all of the possibilities. Since the policy options are virtually unlimited, it is possible to package any number of actions (some more significant than others) which would have the net effect of a total restructuring of the program. This decision should, however, be approached with extreme caution in order to avoid unintentional and undesirable effects on both the program itself and the fundamental objectives and policies of the Comprehensive Management Plan.

One must also consider the extent to which these types of actions will contribute to a perception that the PDC program is impermanent and, therefore, can not be relied upon as developers, municipalities, and property owners make important investment and land use decisions. Additionally, it is advisable to consider the extent to which change might be resisted. The PDC program undeniably suffered from these factors at the outset and may again suffer if refinements are not carefully considered.

Consequently, the recommendations presented for Commission consideration are deliberately designed to avoid significant structural changes in the program. They are also presented in three groups, reflecting different degrees of intervention into the current program.

\section{A. ACTIONS INVOLVING VIRTUALLY NO STROCTURAL CHANGE IN THE PDC PROGRAM OR THE CMP.}

These represent steps which the Commission can take without affecting the structure of the program.

\section{A.1) PDC Advocacy Staff}

The Pinelañds Commission should seek to establish, in cooperation with the New Jersey Pinelands Development credit Bank, advocates for the PDC program. Informational and educational service as well as technical assistance should be made available to property owners who are entitled to a PDC allocation and to developers who may use PDCs. As was the case in Montgomery County, MD, two positions (one geared toward property owners and the other to developers) should be established for a three year period. These should be senior level positions which would be occupied by individuals with 
ample training and experience in real estate, land development, and municipal zoning and planning.

The costs for such a three year program are estimated at $\$ 300,000$. If the Bank and the Commission can each contribute $\$ 25,000$ per year, outside funding of $\$ 150,000$ would be needed. Although additional state appropriations may be possible, funding from one or more private foundations is suggested as a means to avoid delays.

\section{A.2) Re-examination of Municipal zoning}

The Pinelands Commission should undertake a comprehensive re-examination of the municipal zoning scheme in each Pinelands Regional Growth Area. The re-examination should have four primary objectives.

First, ordinance standards relative to PDC densities and associated bulk standards should be set forth clearly and concisely in zoning district regulations.

Second, a comprehensive analysis of the potential for conditional use (e.g. planned development) approvals and their affect on CMP development capacities should be undertaken. If it is found that the potential for these higher density, conditional uses will lead to development levels exceeding those specified in the CMP, municipalities should be required to revise their zoning schemes accordingly.

Third, land tenure patterns and environmental constraints should be examined in each municipality to ensure that zoning schemes are sensitive to these development limitations.

Fourth, base and bonus density standards should be reconfigured to encourage a higher proportion of PDC use in lower density zones without changing overall development levels. For example, a municipality with high and low density zones may have apportioned a greater percentage of PDC use to the higher density zone. Without changing maximum permitted densities, the threshold for-PDC use could be reduced in the low density zone and raised in the high density zone.

Such an effort will involve a substantial commitment of staff resources. Under current staffing conditions, it is estimated that a two year period will be needed to complete this project. 


\section{A.3) New Endorsements for Pinelands Infrastructure Trust Sewer Projects}

The Pinelands Commission should immediately seek new endorsements from sponsors of Pinelands Infrastructure Trust sewer projects. Absent affirmative endorsements, grant and loan offers should be withdrawn. Re-examination of funding priorities should be undertaken, as scheduled, in the winter of 1989. Moreover, a greater effort should be made on behalf of project sponsors to facilitate DEP review and approval of project designs.

\section{A.4) Simplify CMP Re: Variance and Retained Right to Build}

The Pinelands Commission should immediately propose amendments to the Pinelands Comprehensive Management plan to clarify and simplify two PDC related provisions of the plan. The first would involve: deletion of that portion of N.J.A.C. $7: 50-5.28$ (a) $3 i \mathrm{i}$ which has been interpreted to mean that PDCs are not necessarily needed if residential densities are exceeded by virtue of a variance approval; and the addition of a standard which requires that use variances allowing non-residential development in a PDC receiving zone be recognized only when the PDCs otherwise permitted to be used on the property are redeemed. (The CMP currently requires PDC use when residential development is approved by variance in a non-residential zone but does not deal with the opposite situation.)

Second, the method for calculating PDC allocations when homes are already located on a property or when a residential development is to be retained should be simplified by merely adjusting the allocation by .25 PDC for each such home or right retained. This simple change will help alleviate what is quickly becoming an extremely difficult adjustment process to explain and understand.

\section{A.5) Priority Review for PDC Projects}

Development projects proposing the use of PDCs should be afforded priority review status by Pinelands Commission staff. Although this should in no way be perceived as a relaxation of Pinelands development standards, the fact remains that Pinelands review periods can be shortened merely by attaching a greater priority to the review of PDC development applications. This may represent, unto itself, a relatively minor inducement but it will save time and signal the Commission's interest in 
allocating staff resources to what it considers an important class of projects.

In taking this step, it must be recognized that the review periods for other types of projects may be lengthened; however, the quality of the staff's review will not change.

B. ACTIONS WHICH WOULD HAVE LITTLE STRUCTURAL EFFECT ON THE PDC PROGRAM OR CMP.

If the Commission determines that the aforementioned steps by themselves may not result in the desired level of program improvement, several additional program changes can be considered. Although these carry with them more significant program implications, it is felt that they can be implemented without greatly altering the basic structure of the PDC program or the Comprehensive Management Plan.

\section{B.1) Simplified Allocation and Redemption Formula}

The Pinelands Development Credit allocation and redemption formula can be modified to achieve a one to one correlation. The conversion process now in place (e.g. 2 PDCs per 39 acres, each of which yields four bonus units) is difficult for many people to comprehend and discourages participation in the program. To simplify matters, the redemption formula can be changed so that one PDC is equal to one bonus unit if, at the same time, the allocation formula is similarly revised. Although the total number of residential development rights available for allocation and redemption would remain unchanged, the formulas would be much easier to understand.

Although this does not represent a structural change, the transition would undoubtedly confuse some people and may temporarily have a negative, rather than positive, effect.

\section{B.2) Limit PDC Use at Higher Densities}

Establish a threshold density above which PDC use must be limited. Retaining the same proportion of non-PDC to PDC development and the same maximum zone capacities as now exist, the Commission could establish a set density above which PDC use would have to be limited. 
Since the highest PDC values are found at densities no greater than $4 \mathrm{du} / \mathrm{ac}$ and since the vast majority of development now taking place is at or below that same level, the Commission could establish a policy to require that $75 \%$ of all PDC redemption opportunities be provided at densities no greater than 4 du/acre. N.J.A.C. 7:50-5.28(a)3 already requires that "a reasonable proportion of the density increase permit[s] the development of single family detached residences ...." Therefore, there may be no need to further amend the CMP in order to implement this policy.

Table 28 illustrates how this policy might be implemented. A municipality currently has two PDC receiving zones: the RG-1 zone permits a density of 2 du/acre without PDCs and 3 du/acre with PDCs; the RG-2 zone permits a density of $4 \mathrm{du} / \mathrm{ac}$ without PDCs and $6 \mathrm{du} / \mathrm{ac}$ with PDCs. In this case, two thirds of the PDCs may only be redeemed if development occurs in the RG-2 zone at a density of $6 \mathrm{du} / \mathrm{acre}$. Keeping the maximum densities in each zone intact, the municipality could meet the policy by triggering PDC use in the RG-1 zone at a density of $1.5 \mathrm{du} / \mathrm{acre}$ and by establishing a discrete range of 3.5 du/acre to 5.0 du/acre for PDC use in the RG-2 zone. The RG-2 zone would still permit maximum densities of 6 du/acre but no PDC use would be required for densities above 5 du/acre. 
Table 28. Example of the Application of a Maximum Density Threshold for PDC Use

\begin{tabular}{|c|c|c|c|}
\hline $\begin{array}{l}\text { Zoning } \\
\text { District }\end{array}$ & $\begin{array}{l}\text { Zone } \\
\text { Details }\end{array}$ & $\begin{array}{l}\text { Current } \\
\text { Zoning } \\
\text { Scheme }\end{array}$ & $\begin{array}{l}\text { Revised } \\
\text { Zoning } \\
\text { Scheme }\end{array}$ \\
\hline \multirow[t]{7}{*}{ RG-1 } & Vacant land & 200 & 200 \\
\hline & $\begin{array}{l}\text { Maximum density per- } \\
\text { mitted in district }\end{array}$ & $3 \mathrm{du} / \mathrm{ac}$ & $3 \mathrm{du} / \mathrm{ac}$ \\
\hline & $\begin{array}{l}\text { PDC use required at } \\
\text { this density range }\end{array}$ & $2-3 \mathrm{du} / \mathrm{ac}$ & $1 \cdot 5-3 \mathrm{du} / \mathrm{ac}$ \\
\hline & $\begin{array}{l}\text { Maximum number of units } \\
\text { permitted absent PDC use }\end{array}$ & 400 & 300 \\
\hline & $\begin{array}{l}\text { Maximum number of units } \\
\text { permitted with PDCs at } \\
\text { a density } \leq 4 \mathrm{du} / \mathrm{ac}\end{array}$ & 200 & 300 \\
\hline & $\begin{array}{l}\text { Maximum number of units } \\
\text { permitted with PDCs at } \\
\text { a density }>4 \mathrm{du} / \mathrm{ac}\end{array}$ & 0 & 0 \\
\hline & Total zone capacity & 600 & 600 \\
\hline \multirow[t]{7}{*}{ RG-2 } & Vacant land & 200 & 200 \\
\hline & $\begin{array}{l}\text { Maximum density per- } \\
\text { mitted in district }\end{array}$ & $6 \mathrm{du} / \mathrm{ac}$ & $6 \mathrm{du} / \mathrm{ac}$ \\
\hline & $\begin{array}{l}\text { PDC use required at } \\
\text { this density range }\end{array}$ & $4-6 \mathrm{du} / \mathrm{ac}$ & $3.5-5.0 \mathrm{du} / \mathrm{ac}$ \\
\hline & $\begin{array}{l}\text { Maximum number of units } \\
\text { permitted absent PDC use }\end{array}$ & 800 & 900 \\
\hline & $\begin{array}{l}\text { Maximum number of units } \\
\text { permitted with PDCs at } \\
\text { a density } \leq 4 \mathrm{du} / \mathrm{ac}\end{array}$ & 0 & 100 \\
\hline & $\begin{array}{l}\text { Maximum number of units } \\
\text { permitted with PDCs at } \\
\text { a density of }>4 \mathrm{du} / \mathrm{ac}\end{array}$ & 400 & 200 \\
\hline & Total zone capacity & 1200 & 1200 \\
\hline
\end{tabular}


Table 28. Example of the Application of a Maximum Density Threshold for PDC Use (Continued)

$\begin{array}{ccll} & & \text { Current } & \text { Revised } \\ \text { Zoning } & \text { Zone } & \text { Zoning } & \text { Zoning } \\ \text { District } & \text { Details } & \text { Scheme } & \text { Scheme }\end{array}$

Municipal Maximum number of nonTotals PDC units permitted

Maximum number of PDC units permitted

1200

1200

Total units permitted

1800

1800

8 of PDC units permit-

338

758

$\leq 4 \mathrm{du} / \mathrm{ac}$

8 of PDC units permitted at densities

678

600

$>4 \mathrm{du} / \mathrm{ac}$ 


\section{B.3) Revised Municipal Reserve Conversion}

Amend the Comprehensive Management Plan to reguire that Municipal Reserves, when triggered for higher levels of development, utilize PDCs for all development at densities higher than 1 du/acre. Municipal Reserves are portions of Rural Development Areas which have been designated as primary development areas once adjacent Regional Growth Areas are developed. Although few municipal reserves have been designated to date, there is a distinct probability that more may be designated in the future. Rural Development Areas are, for the most part, zoned at densities of 1 home per 5 acres.

In consideration of higher density zoning being permitted in the future, the Commission could require that PDC use be required for residential development exceeding a density of 1 du/acre. Maximum zone capacities would be based upon the average density applicable to the adjacent Regional Growth Area.

Higher densities ( 1 du/acre versus 1 -du/5 acres) would thus be permitted without PDC use yet additional PDC opportunities could be provided at the same time. 
C. ACTIONS -INVOLVING MORE SUBSTANTIAL CHANGES TO THE PDC PROGRAM AND THE CMP.

If more substantive changes are felt to be necessary, the following recommendations may be implemented without drastically altering either the PDC program or the CMP. Both of these recommendations would be targeted to specific situations and not applied universally throughout the Region.

\section{C.1) Guaranteed Residential PDC Use Option}

The Commission could amend the Comprehensive Management Plan to permit municipalities to reduce maximum residential zone capacities if PDC use were made an element of most residential developments. The CMP currently requires that a 508 increment in the maximum amount of residential development be permitted when PDCs are used. Under this proposal, a municipality could be afforded an opportunity to reduce or eliminate this increment if PDCs were required to be used for a portion of the density approved for most residential developments. Small scale projects could be exempted from PDC use.

Table 29 provides an example of how this approach might work. In the example, a municipality must currently zone for a maximum development capacity of 3000 units, 1000 of which may be built only if higher density projects ( 4 to $6 \mathrm{du} / \mathrm{ac}$ ) utilize PDCs. If the municipality wishes to reduce this maximum development capacity, it may zone for no less than 2000 units, the amount of residential development heretofore permitted without PDC use. In return, the municipality will require that one-half of that lost development potential be re-allocated for PDC use. This amounts to 500 out of the 2000 units or 1 out of every 4 approved for development. 
Table 29. Example of the Application of a Proportionate PDC Redemption Program

\begin{tabular}{|c|c|c|}
\hline & $\begin{array}{l}\text { Current } \\
\text { Zoning }\end{array}$ & $\begin{array}{r}\text { Revised } \\
\text { Zoning }\end{array}$ \\
\hline Vacant Land & 500 ac. & 500 ac. \\
\hline $\begin{array}{l}\text { Maximum density permitted in } \\
\text { district }\end{array}$ & $6 \mathrm{du} / \mathrm{a}$ & $4 d u / a$ \\
\hline $\begin{array}{l}\text { PDC use required at this density } \\
\text { range }\end{array}$ & $4-6 d u / a$ & $\begin{array}{l}\text { Use required } \\
\text { regardless of } \\
\text { density }\end{array}$ \\
\hline Required proportion of PDC use & None & $\begin{array}{l}1 \text { PDC unit in } \\
\text { every } 4 \text { units } \\
\text { approved }\end{array}$ \\
\hline Exempted from PDC use & $\begin{array}{l}\text { All projects } \\
\text { at a density } \\
\text { less than } \\
4 \mathrm{du} / \text { acre }\end{array}$ & $\begin{array}{l}\text { All projects } \\
\text { involving less } \\
\text { than } 4 \text { units }\end{array}$ \\
\hline $\begin{array}{l}\text { Maximum number of units permitted } \\
\text { absent PDC use }\end{array}$ & 2000 units & 0 units (1) \\
\hline $\begin{array}{l}\text { Maximum number of units permitted } \\
\text { with PDC use }\end{array}$ & 1000 units & 500 units \\
\hline Total zone capacity & 3000 units & 2000 (1) \\
\hline $\begin{array}{l}\text { PDC use if development in the } \\
\text { zone has an an average density } \\
\text { of } 2 \mathrm{du} / \mathrm{acre}\end{array}$ & 0 units & 250 \\
\hline $\begin{array}{l}\text { PDC use if development in the } \\
\text { zone has an average density } \\
\text { of } 3 \text { du/acre }\end{array}$ & 0 units & 375 \\
\hline
\end{tabular}


Table 29. Example of the Application of a Proportionate PDC Redemption Program (Continued)

PDC use if development in the
$\begin{aligned} & \text { zone has an average density } \\ & \text { of } 4 \text { du/acre }\end{aligned}$

Although the maximum PDC unit potential has been cut in half, PDC use is guaranteed. Since virtually all development shares equally in the program regardless of the density at which the projects are built, reducing the maximum PDC use potential is acceptable. Since this approach would not have universal application and the current PDC program is structured so that roughly twice as many opportunities for PDC use are afforded than there are PDCs available for use, in no case will this result in fewer redemption opportunities than there are PDCs available for allocation. 


\section{C.2) Commercial and Industrial Use Option}

The Commission could amend the Comprehensive Management Plan to permit municipalities to offset PDC use in residential zones by affording an opportunity for their use in commercial and industrial zones. This option would be used when:

- a municipality requests it as a means to lower maximum development capacities as long as base levels are maintained; or

- the Pinelands Commission determines that a municipality's residential zoning scheme allocates too much PDC use in high density zones which are unlikely to be developed at those densities.

The Commission would need to develop a formula to govern PDC use in commerciaz and industrial developments based upon:

- a minimum square footage threshold which permits neighborhood commercial and localized industrial uses to be built without PDC use; and

- additional square footage being permitted on the basis of PDC use.

The formula would be structured such that the estimated value of a PDC would be roughly equivalent to the value ranges estimated for lower density residential development.

An economic analysis similar to that completed for this evaluation would need to be undertaken, after which an amendment to the CMP would be made. During this period, however, preliminary planning work could begin with interested municipalities in an effort to identify the zones, uses, and amount of residential and non-residential development which might be governed by such a change.

\section{SUMMARY}

It is important to note that, while most of these recommendations can be implemented in tandem, several can not. Recommendations B.2) and C.1) are mutually exclusive and should not be implemented in tandem. It would also appear unwise to select one of those two and couple it with all of the other actions which do involve at least some structural changes. 


\section{THE PINELANDS DEVELOPMENT CREDIT PROGRAM}

\section{APPENDICES}

A. Burlington County PDC Bank Purchases by Date, Management Area, and Municipality

B. Status Report on Development Applications Where PDCs Are Being or May Be Used

C. Housing Sales Data Crosstabluations

D. Economic Analysis of Pinelands Development Credits

E. Policy and Program Alternatives 


\title{
OCT 2 i 1988
}

A REPORT ON THE ECONOMIC VALUE OF PINELANDS DEVELOPMENT CREDITS

Prepared for the

NEW JERSEY PINELANDS COMMISSION

\author{
By \\ James C. Nicholas \\ Professor of Urban and Regional Planning \\ University of Florida \\ Gainesvilie, FL 32611
}

August 1988 
APPENDIX A.

Burlington County PDC Bank Purchases by Date, Management Area, and Municipality 
Burlington County PDC Purchases by Year (As of $8 / 5 / 88$ )

$\begin{array}{lcr}\begin{array}{l}\text { Municlpality } \\ \text { Year } 82\end{array} & \text { Acres } & \text { PDCs Date } \\ \text { Woodland } & & \\ & 215.00 & 4.50821022 \\ & 215.00 & 4.50 \\ \text { औear } 83 & & \\ \text { Tabernacle } & 65.70 & 3.25830415 \\ \text { Woodland } & 0.28 & 0.25830909 \\ \text { Woodland } & 1.82 & 0.75830622 \\ \text { Washington } & 52.75 & 1.50831023 \\ \text { Southampton } & 801.00 & 29.75831019 \\ - & 921.55 & 35.50\end{array}$

* Year 84

Shamong

Washington

Tabernacle

Woodland

Woodland

12.90

146.80

110.85

354.04

111.95

35.50

$736.54 \quad 26.75$

- Year 85

Woodland

Bass River

Washington

10.01

23.73

$0.50 \quad 840328$

1.00840928

4.75840905

$14.75 \quad 841228$

5.75841224

\begin{tabular}{ccc}
363.00 & 6.25850820 \\
\hline 396.74 & 7.25
\end{tabular}

- Year 86

Pemberton

Pemberton

32.19

75.13

1.75860523

2.75861231

107.32

4.50

- Year 87

Pemberton

58.54

2.25870220

58.54

2.25

- Year 88 (A11 awalting closing)

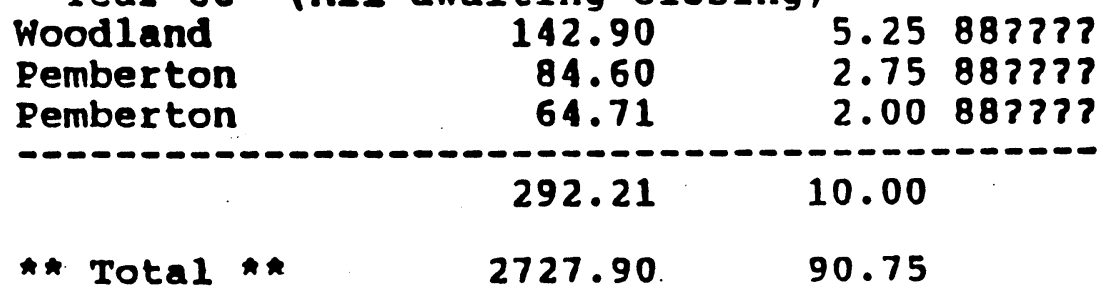

Appendix A Page 1 
Burlington County PDC Purchases by Management Area (As of $8 / 5 / 88$ )

$\begin{array}{lc}\text { Mgt Area } & \text { Municipa } \\ \text { * Management Area AG } \\ \text { AG } & \text { Southampton } \\ \text { AG } & \text { Pemberton } \\ \text { AG } & \text { Pemberton } \\ \text { AG } & \text { Pemberton } \\ \text { AG } & \text { Pemberton } \\ \text { AG } & \text { Pemberton } \\ \text { * subtotal } * *\end{array}$

Acres PDCs

$* *$ Subtotal $* *$

$\begin{array}{rr}801.00 & 29.75 \\ 32.19 & 1.75 \\ 75.13 & 2.75 \\ 58.54 & 2.25 \\ 84.60 & 2.75 \\ 64.71 & 2.00\end{array}$

$1116.17 \quad 41.25$

* Management Area PA

$\begin{array}{ll}\text { PA } & \text { Woodland } \\ \text { PA } & \text { Woodland } \\ \text { PA } & \text { Woodland } \\ \text { PA } & \text { Washington } \\ \text { PA } & \text { Shamong } \\ \text { PA } & \text { Woodland } \\ \text { PA } & \text { Bass River } \\ \text { PA } & \text { Washington } \\ \star \star & \text { subtotal } \star *\end{array}$

215.00

4.50

0.28

0.25

1.82

0.75

52.75

1.50

12.90

0.50

111.95

5.75

23.73

0.25

363.00

6.25

.781 .43

19.75

$\begin{array}{ll}\text { * Management Area SAG } \\ \text { SAG } & \text { Tabernacle } \\ \text { SAG } & \text { Washington } \\ \text { SAG } & \text { Tabernacle } \\ \text { SAG } & \text { Woodland } \\ \text { SAG } & \text { Woodland } \\ \text { SAG : } & \text { Woodland } \\ \star \star \text { Subtotal } \star \star\end{array}$

65.70

146.80

110.85

354.04

10.01

142.90

3.25

1.00

4.75

14.75

0.75

5.25

830.30

29.75

** Total

2727.90

90.7 .5

Note: Includes 3 transactions approved, awaiting closing. 
Burlington County PDC Purchases by Munlclpality as of (8/5/88)

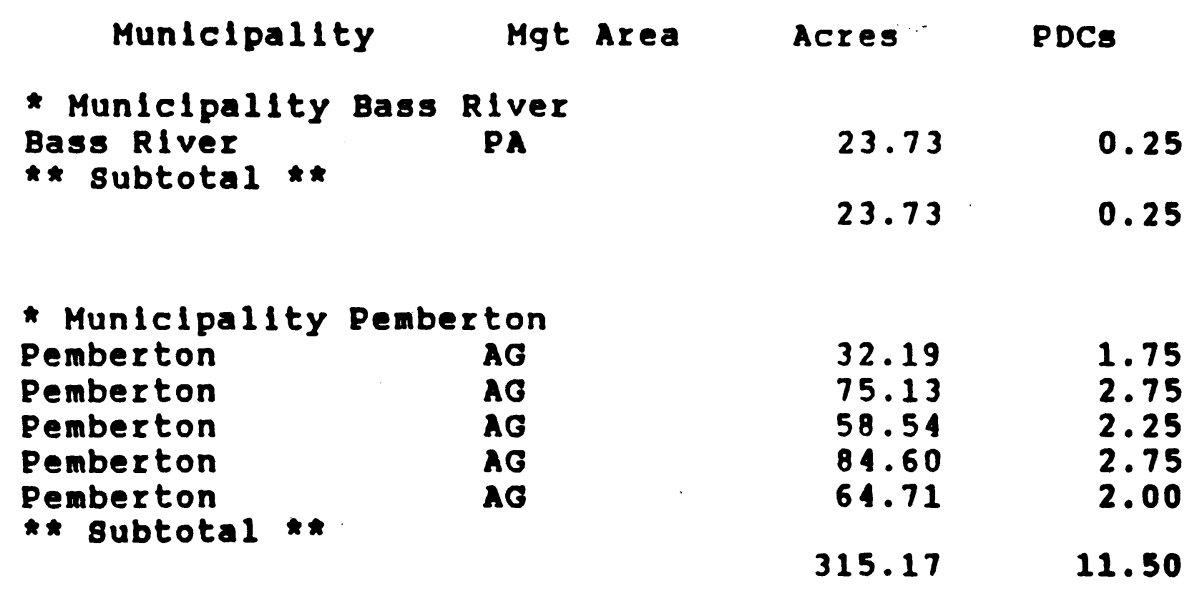

* Municipality shamong

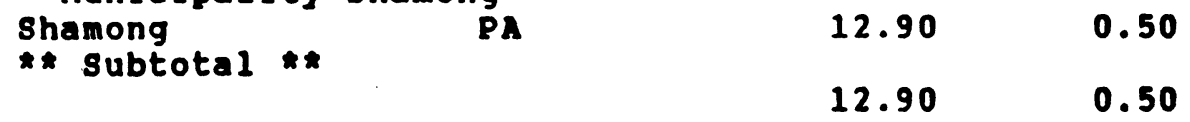

* Municipality southampton

$\begin{array}{llll}\text { Southamptón } & \text { AG } & 801.00 & 29.75 \\ * \text { Subtotal } * & 801.00 & 29.75\end{array}$

* Municlpality Tabernacle $\begin{array}{ll}\text { Tabernacle } & \text { SAG } \\ \text { Tabernacle } & \text { SAG }\end{array}$ $*$ 8ubtotal *

$65.70 \quad 3.25$

$110.85 \quad 4.75$

176.558 .00

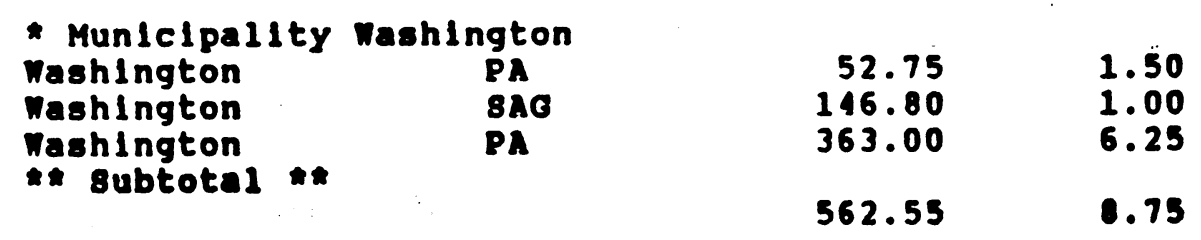

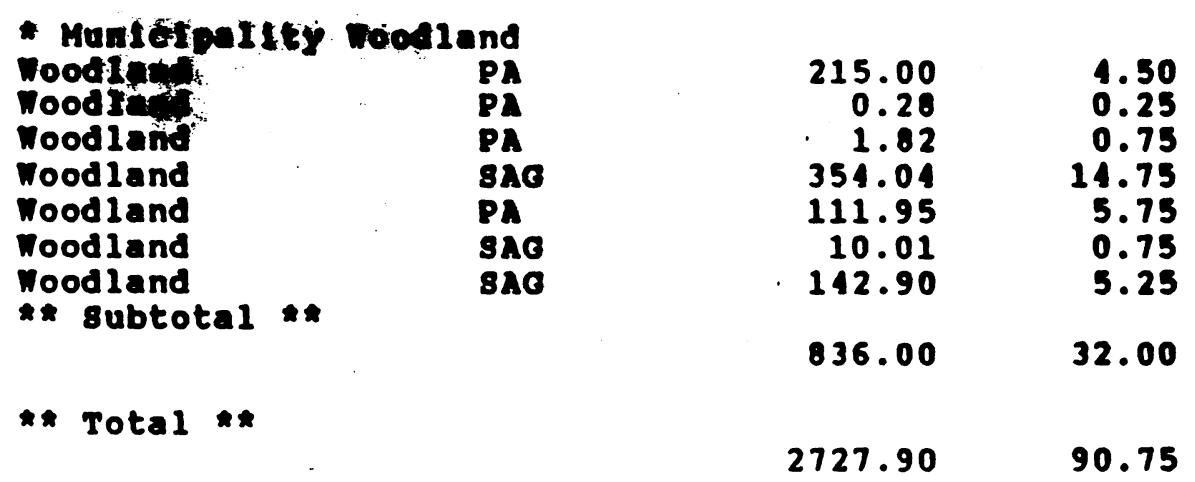

Note: Includes 3 transactlons approved, avalting closing. 


\begin{abstract}
APPENDIX B.
Status Report on Development Applications Where PDCs Are Being or May Be Used
\end{abstract}


PAGE NO. 1

Projects Using Pinelands Development Credits

PD2

Appl Applicant

PDC's Project

PDCs Needed Status

Purchased

Note

Num

From

* * MUNICIPALITY EGG HARBOR

81-1253 Ciarkowski (Abram

Simoff Assoc.)

8.00 Active

$83-6358$

Will Guerro

16.25 Approved

Burlco

$85-1008.2$

Midelton (Karl-Le

Partnership)

0.75 Approved Burlco

* * MUNICIPALITY GALLOWAY

87-0690 Ole Hansen \& Sons, Inc

487.50 Uncertain

* * MUNICIPALITY HAMILTON

$\begin{array}{ll}81-1321 & \text { Lordland } \\ 81-0562 & \text { Acmak/Kravco } \\ 84-0309 & \text { Greenberg } \\ 86-0490.2 & \text { Amerigo Liberati } \\ 81-0852 & \text { ACRA }\end{array}$

272.00 Uncertain

38.75 Approved

15.00 Uncertain

0.25 Active

9.75 Approved Burlco

(2.00)

$\begin{array}{llll}\begin{array}{l}\text { * } \\ 81-2462\end{array} & \begin{array}{l}\text { MUNICIPALITY MEDFORD } \\ \text { Carlisle } \\ \text { Enterprises }\end{array} & 1.50 \text { Built } & \text { Burlco } \\ 84-0657 & \begin{array}{l}\text { Chippewa } \\ \text { Associates }\end{array} & 1.25 \text { Built } & \text { Burlco } \\ 84-0926 & \text { Michael Garvey } & 0.75 \text { Built } & \begin{array}{l}\text { Blue Ja } \\ \text { Forestr } \\ \text { Land Us } \\ \text { Corp }\end{array} \\ 86-0633 & \text { Robert Churchill } & & \text { C.75 Approved } \\ 85-0786 & \text { Franks Assoc } & 0.25 \text { Approved Burlco } \\ 1-0576 & \text { Bruce Martin } & 2.00 \text { Approved Burlco }\end{array}$




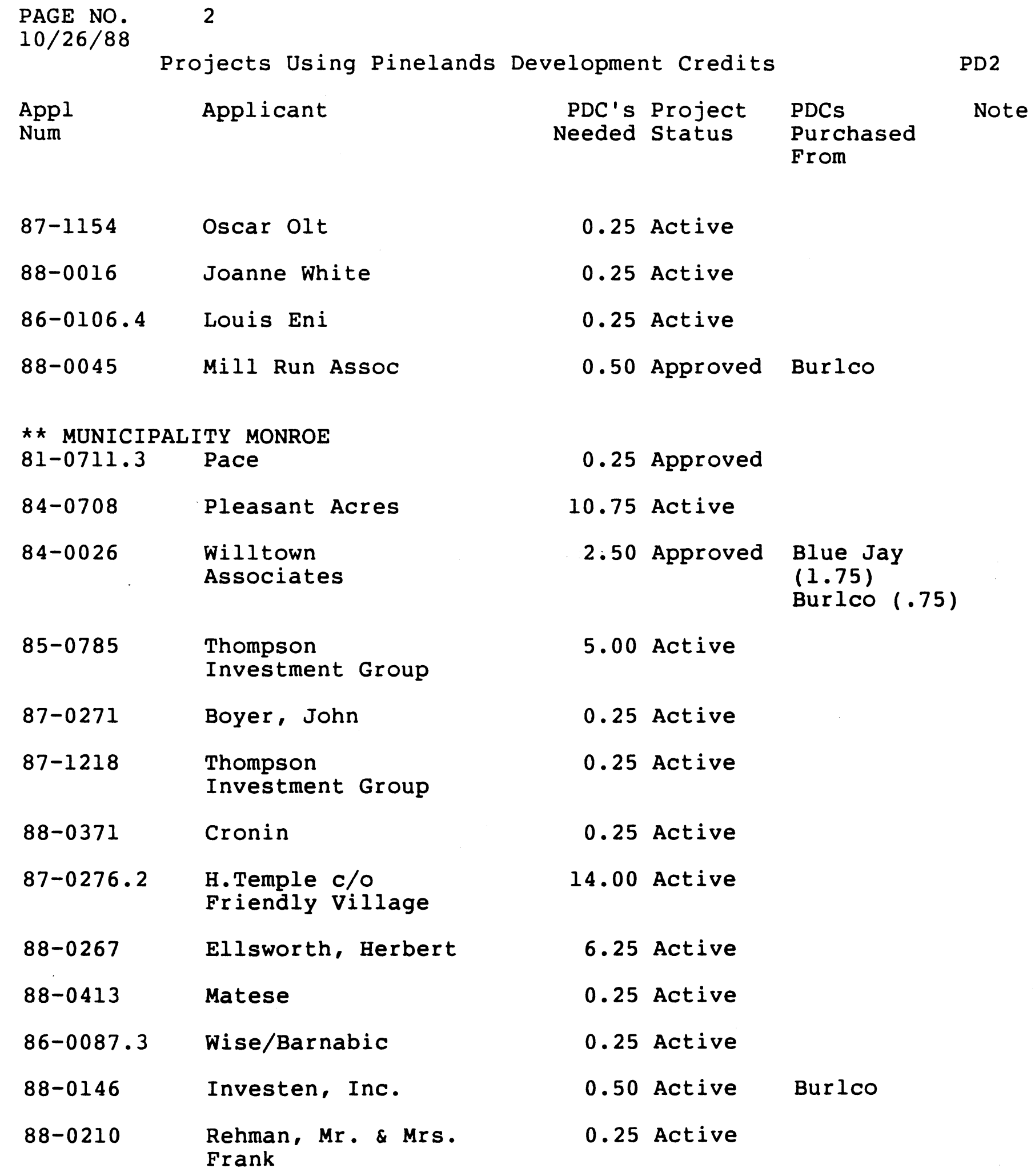

PAGE NO.

Projects Using Pinelands Development Credits PDC's Project Needed Status

0.25 Active

0.25 Active

0.25 Active

0.50 Approved

0.25 Approved

10.75 Active

2.50 Approved

(1.75)

Burlco

(.75)

* * MUNICIPALITY PEMBERTON

83-10,248 Angivoli, Anth \& Ed

4.00 Active 
PAGE NO. 3

$10 / 26 / 88$

Projects Using Pinelands Development Credits

PD2

Appl

Applicant

PDC's Project Needed Status

PDCs

Purchased

Note

Num

83-10,325 Wesmar Associates

( $\mathrm{PB})$

84-0184 XEBEC, Inc.

2.50 Built

From

$84-1283 C$

Classical

Associates

0.25 Approved

4.00 Approved

85-1154

Mr. \& Mrs. Nogar

0.25 Active

86-0673

Sebastian Dovi

1.25 Built

Burlco

81-0640

Edward Friet/DFE

Corp.

25.00 Uncertain

88-0835

Tamaccio Brothers

2.00 Active

** MUNICIPALITY TABERNACLE

88-0282 Bricketto/Pray

4.50 Active

* * MUNICIPALITY WATERFORD

81-0477 Pagano

0.75 Built

Burlco

81-0569

Pliner (South

Jersey Investors)

7.50 Approved

Blue Jay

(3), Burlco

(7)

$(4.5)$

85-0153 Tirro, Albert

5.00 Approved Burlco (4.5)

87-0587.2 Mersky, Sanford

0.25 Active

** MUNICIPALITY WINSLOW

81-0862 Atco Lake

Assoc/Ettore/M\&E

12.25 Approved Burlco

Notes:

(1) PDC use estimated on the basis of applicant's interest in developing a Planned Industrial Residential Development at the maximum PDC density of 8 du/ac. Hovnanian has recently expressed an interest in purchasing this project. 
Notes (Continued):

(2) Funds have been reserved for the purchase of 4 PDCs in the applicant's first phase of development. Additional funds have been reserved for purchase of PDCs for the second phase.

Under construction.

(3) Under construction.

(4) 64 units have been approved, 16 additional units that require PDCs have not yet been approved.

(5) May require 25 to 100 pdcs.

(6) 8 to 10 Apartment units in non-residential zone will require a use variance and purchase of 2 to 2.5 PDCs.

(7) Under construction.

(8) Variance denied.

(9) Under construction. 
$10 / 26 / 88$

Status Summary for projects Using PDCs

\begin{tabular}{|c|c|c|c|c|c|c|c|c|c|c|}
\hline \multirow[b]{2}{*}{ Municipality } & \multicolumn{2}{|c|}{ Built } & \multicolumn{2}{|c|}{ Approved } & \multicolumn{2}{|c|}{ Active } & \multicolumn{2}{|c|}{ Uncertain } & \multicolumn{2}{|c|}{ Total } \\
\hline & Proj & PDCs & Proj & PDCs & Proj & PDCs & Proj & PDCs & Proj & PDCs \\
\hline $\begin{array}{l}\text { EGG HARBOR } \\
\text { GALLOWAY } \\
\text { HAMILTON } \\
\text { MEDFORD } \\
\text { MONROE } \\
\text { PEMBERTON } \\
\text { TABERNACLE } \\
\text { WATERFORD } \\
\text { WINSLOW }\end{array}$ & $\begin{array}{l}0 \\
0 \\
0 \\
3 \\
0 \\
2 \\
0 \\
1 \\
0\end{array}$ & $\begin{array}{l}0.00 \\
0.00 \\
0.00 \\
3.50 \\
0.00 \\
3.75 \\
0.00 \\
0.75 \\
0.00\end{array}$ & $\begin{array}{l}2 \\
0 \\
2 \\
4 \\
2 \\
2 \\
0 \\
2 \\
1\end{array}$ & $\begin{array}{r}17.00 \\
0.00 \\
48.50 \\
3.50 \\
2.75 \\
4.25 \\
0.00 \\
12.50 \\
12.25\end{array}$ & $\begin{array}{r}1 \\
0 \\
1 \\
3 \\
11 \\
3 \\
1 \\
1 \\
0\end{array}$ & $\begin{array}{r}8.00 \\
0.00 \\
0.25 \\
0.75 \\
38.00 \\
6.25 \\
4.50 \\
0.25 \\
0.00\end{array}$ & $\begin{array}{l}0 \\
1 \\
2 \\
0 \\
0 \\
1 \\
0 \\
0 \\
0\end{array}$ & $\begin{array}{r}0.00 \\
487.50 \\
287.00 \\
0.00 \\
0.00 \\
25.00 \\
0.00 \\
0.00 \\
0.00\end{array}$ & $\begin{array}{r}3 \\
1 \\
5 \\
10 \\
13 \\
8 \\
1 \\
4 \\
1\end{array}$ & $\begin{array}{r}25.00 \\
487.50 \\
335.75 \\
7.75 \\
40.75 \\
39.25 \\
4.50 \\
13.50 \\
12.25\end{array}$ \\
\hline Total & 6 & 8.00 & 15 & 100.75 & 21 & 58.00 & 4 & 799.50 & 46 & 966.25 \\
\hline
\end{tabular}


APPENDIX C.

Housing Sales Data Crosstabluations 
APPENDIX C.

Housing Sales Data Crosstabluations 
GROSS DENSITY

Medford

Number of Data Points

\begin{tabular}{rr}
\multicolumn{2}{c}{ Density } \\
\hline At & Less \\
\hline 0 & Than \\
0.5 & 0.5 \\
1 & 1 \\
2 & 2 \\
3 & 4 \\
4 & 6 \\
6 & 8 \\
8 & 10 \\
10 & 12 \\
12 & 20 \\
20 & 99 \\
- & 9
\end{tabular}

Housing Type

\begin{tabular}{|c|c|c|c|}
\hline $\begin{array}{r}\text { Single } \\
\text { Detached }\end{array}$ & $\begin{array}{l}\text { Town- } \\
\text { house }\end{array}$ & $\begin{array}{l}\text { Condo- } \\
\text { Apt. }\end{array}$ & Total \\
\hline $\begin{array}{r}17 \\
91 \\
8 \\
2 \\
0 \\
0 \\
0 \\
0 \\
0 \\
0 \\
0\end{array}$ & $\begin{array}{l}0 \\
0 \\
0 \\
0 \\
0 \\
0 \\
0 \\
0 \\
0 \\
0 \\
0\end{array}$ & $\begin{array}{r}0 \\
0 \\
0 \\
0 \\
0 \\
0 \\
35 \\
0 \\
0 \\
0 \\
0\end{array}$ & $\begin{array}{r}17 \\
91 \\
8 \\
2 \\
0 \\
0 \\
35 \\
0 \\
0 \\
0 \\
0\end{array}$ \\
\hline 118 & 0 & 35 & 153 \\
\hline
\end{tabular}

Percent of units

\begin{tabular}{cc}
\multicolumn{2}{c}{ Density } \\
\hdashline At & Less \\
Least & Than
\end{tabular}

\begin{tabular}{|c|c|c|c|}
\hline $\begin{array}{r}\text { Single } \\
\text { Detached }\end{array}$ & $\begin{array}{l}\text { Town- } \\
\text { house }\end{array}$ & $\begin{array}{l}\text { Condo- } \\
\text { Apt. }\end{array}$ & Total \\
\hline $\begin{array}{l}14.48 \\
77.18 \\
6.88 \\
1.78 \\
0.08 \\
0.08 \\
0.08 \\
0.08 \\
0.08 \\
0.08 \\
0.08-\end{array}$ & $\begin{array}{l}n / a \\
n / a \\
n / a \\
n / a \\
n / a \\
n / a \\
n / a \\
n / a \\
n / a \\
n / a \\
n / a\end{array}$ & $\begin{array}{r}0.08 \\
0.08 \\
0.08 \\
0.08 \\
0.08 \\
0.08 \\
100.08 \\
0.08 \\
0.08 \\
0.08 \\
0.08\end{array}$ & $\begin{array}{r}11.18 \\
59.58 \\
5.28 \\
1.38 \\
0.08 \\
0.08 \\
22.98 \\
0.08 \\
0.08 \\
0.08 \\
0.08\end{array}$ \\
\hline $100.0 \%$ & $n / a$ & $100.0 \%$ & 100.08 \\
\hline
\end{tabular}




\begin{tabular}{|c|c|c|c|c|c|}
\hline \multicolumn{6}{|c|}{$\begin{array}{c}\text { GROSS DENSITY } \\
\text { Winslow }\end{array}$} \\
\hline \multicolumn{6}{|c|}{ Number of Data Points } \\
\hline \multicolumn{2}{|c|}{ Density } & \multicolumn{3}{|c|}{ Housing Type } & \\
\hline $\begin{array}{r}\text { At } \\
\text { Least }\end{array}$ & $\begin{array}{l}\text { Less } \\
\text { Than }\end{array}$ & $\begin{array}{r}\text { Single } \\
\text { Detached }\end{array}$ & $\begin{array}{l}\text { Town- } \\
\text { house }\end{array}$ & $\begin{array}{l}\text { Condo- } \\
\text { Apt. }\end{array}$ & Total \\
\hline $\begin{array}{r}0 \\
0.5 \\
1 \\
2 \\
3 \\
4 \\
6 \\
8 \\
10 \\
12 \\
20\end{array}$ & $\begin{array}{r}0.5 \\
1 \\
2 \\
3 \\
4 \\
6 \\
8 \\
10 \\
12 \\
20 \\
99\end{array}$ & $\begin{array}{r}0 \\
4 \\
21 \\
41 \\
36 \\
8 \\
15 \\
16 \\
2 \\
0 \\
0\end{array}$ & $\begin{array}{r}0 \\
0 \\
0 \\
0 \\
0 \\
0 \\
57 \\
0 \\
0 \\
0 \\
0\end{array}$ & $\begin{array}{l}0 \\
0 \\
0 \\
0 \\
0 \\
0 \\
0 \\
0 \\
0 \\
0 \\
0\end{array}$ & $\begin{array}{r}0 \\
4 \\
21 \\
41 \\
36 \\
8 \\
72 \\
16 \\
2 \\
0 \\
0\end{array}$ \\
\hline & & 143 & 57 & 0 & 200 \\
\hline \multicolumn{6}{|c|}{ Percent of units } \\
\hline \multicolumn{2}{|c|}{ Density } & \multicolumn{3}{|c|}{ Housing Type } & \\
\hline $\begin{array}{r}\text { At } \\
\text { Least }\end{array}$ & $\begin{array}{l}\text { Less } \\
\text { Than }\end{array}$ & $\begin{array}{r}\text { Single } \\
\text { Detached }\end{array}$ & $\begin{array}{l}\text { Town- } \\
\text { house }\end{array}$ & $\begin{array}{c}\text { Condo- } \\
\text { Apt. }\end{array}$ & Total \\
\hline $\begin{array}{r}0 \\
0.5 \\
1 \\
2 \\
3 \\
4 \\
6 \\
8 \\
10 \\
12 \\
20\end{array}$ & $\begin{array}{r}0.5 \\
1 \\
2 \\
3 \\
4 \\
6 \\
8 \\
10 \\
12 \\
20 \\
99\end{array}$ & $\begin{array}{r}0.08 \\
2.88 \\
14.78 \\
28.78 \\
25.28 \\
5.68 \\
10.58 \\
11.28 \\
1.48 \\
0.08 \\
0.08\end{array}$ & $\begin{array}{r}0.08 \\
0.08 \\
0.08 \\
0.08 \\
0.08 \\
0.08 \\
100.08 \\
0.08 \\
0.08 \\
0.08 \\
0.08\end{array}$ & $\begin{array}{l}n / a \\
n / a \\
n / a \\
n / a \\
n / a \\
n / a \\
n / a \\
n / a \\
n / a \\
n / a \\
n / a\end{array}$ & $\begin{array}{r}0.08 \\
2.08 \\
10.58 \\
20.58 \\
18.08 \\
4.08 \\
36.08 \\
8.08 \\
1.08 \\
0.08 \\
0.08\end{array}$ \\
\hline & & 100.08 & 100.08 & $\mathrm{n} / \mathrm{a}$ & 100.08 \\
\hline
\end{tabular}


GROSS DENSITY

Galloway

Number of Data Points

\begin{tabular}{cr}
\multicolumn{2}{c}{ Density } \\
\hline At & Less \\
\hline Least & Than \\
\hline 0 & 0.5 \\
0.5 & 1 \\
1 & 2 \\
2 & 3 \\
3 & 4 \\
4 & 6 \\
6 & 8 \\
8 & 10 \\
10 & 12 \\
12 & 20 \\
20 & 99 \\
- & --
\end{tabular}

Housing Type

\begin{tabular}{rrrr} 
Single & Town & Condo- & \\
Detached & house & Apt. & Total \\
\hline 1 & 0 & 0 & 1 \\
5 & 0 & 0 & 5 \\
20 & 0 & 0 & 20 \\
1 & 30 & 116 & 147 \\
6 & 0 & 0 & 6 \\
1 & 0 & 1 & 2 \\
0 & 0 & 0 & 0 \\
0 & 0 & 0 & 0 \\
3 & 0 & 16 & 19 \\
0 & 0 & 0 & 0 \\
0 & 0 & 0 & 0 \\
-37 & 30 & 133 & 200
\end{tabular}

Percent of units

Density

\begin{tabular}{rr} 
At & Less \\
Least & Than \\
\hline 0 & 0.5 \\
0.5 & 1 \\
1 & 2 \\
2 & 3 \\
3 & 4 \\
4 & 6 \\
6 & 8 \\
8 & 10 \\
10 & 12 \\
12 & 20 \\
20 & 99 \\
- & 9
\end{tabular}

Housing Type

\begin{tabular}{|c|c|c|c|}
\hline $\begin{array}{r}\text { Single } \\
\text { Detached }\end{array}$ & $\begin{array}{l}\text { Town- } \\
\text { house }\end{array}$ & $\begin{array}{l}\text { Condo- } \\
\text { Apt. }\end{array}$ & Total \\
\hline $\begin{array}{r}2.78 \\
13.58 \\
54.18 \\
2.78 \\
16.28 \\
2.78 \\
0.08 \\
0.08 \\
8.18 \\
0.08 \\
0.08\end{array}$ & $\begin{array}{r}0.08 \\
0.08 \\
0.08 \\
100.08 \\
0.08 \\
0.08 \\
0.08 \\
0.08 \\
0.08 \\
0.08 \\
0.08\end{array}$ & $\begin{array}{r}0.08 \\
0.08 \\
0.08 \\
87.28 \\
0.08 \\
0.88 \\
0.08 \\
0.08 \\
12.08 \\
0.08 \\
0.08\end{array}$ & $\begin{array}{r}0.58 \\
2.58 \\
10.08 \\
73.58 \\
3.08 \\
1.08 \\
0.08 \\
0.08 \\
9.58 \\
0.08 \\
0.08\end{array}$ \\
\hline 100 & 100.08 & 100.08 & 100. \\
\hline
\end{tabular}


GROSS DENSITY

Jackson

Number of Data Points

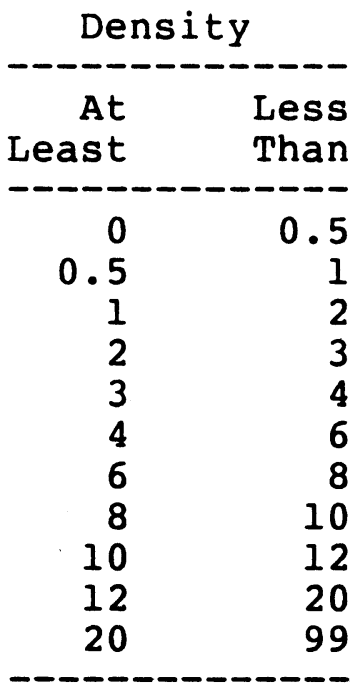

Housing Type

\begin{tabular}{cccc} 
Single & Town & Condo- & \\
Detached & house & Apt. & Total \\
\hline 3 & 0 & 0 & 3 \\
19 & 0 & 0 & 19 \\
23 & 0 & 0 & 23 \\
19 & 0 & 0 & 19 \\
2 & 0 & 0 & 2 \\
0 & 28 & 68 & 96 \\
0 & 38 & 0 & 38 \\
0 & 0 & 0 & 0 \\
0 & 0 & 0 & 0 \\
0 & 0 & 0 & 0 \\
0 & 0 & 0 & 0 \\
-0 & 0 & 68 & 200
\end{tabular}

Percent of units

\begin{tabular}{cr}
\multicolumn{2}{c}{ Density } \\
\hline At & Less \\
Least & Than \\
\hline 0 & 0.5 \\
0.5 & 1 \\
1 & 2 \\
2 & 3 \\
3 & 4 \\
4 & 6 \\
6 & 8 \\
8 & 10 \\
10 & 12 \\
12 & 20 \\
20 & 99 \\
- & -
\end{tabular}

Housing Type

\begin{tabular}{rrrr}
$\begin{array}{c}\text { Single } \\
\text { Detached }\end{array}$ & $\begin{array}{r}\text { Town- } \\
\text { house }\end{array}$ & $\begin{array}{r}\text { Condo- } \\
\text { Apt. }\end{array}$ & Total \\
\hline 4.58 & 0.08 & 0.08 & 1.58 \\
28.88 & 0.08 & 0.08 & 9.58 \\
34.88 & 0.08 & 0.08 & 11.58 \\
28.88 & 0.08 & 0.08 & 9.58 \\
3.08 & 0.08 & 0.08 & 1.08 \\
0.08 & 42.48 & 100.08 & 48.08 \\
0.08 & 57.68 & 0.08 & 19.08 \\
0.08 & 0.08 & 0.08 & 0.08 \\
0.08 & 0.08 & 0.08 & 0.08 \\
0.08 & 0.08 & 0.08 & 0.08 \\
0.08 & 0.08 & 0.08 & 0.08 \\
-1008 & -0.08 & -0.08 \\
\hline 100.08 & 100.08 & 100.08 & 100.08
\end{tabular}


GROSS DENSITY

Unweighted Totals

Number of Data Points

\begin{tabular}{cr}
\multicolumn{2}{c}{ Density } \\
\hline At & Less \\
\hline 0 & Than \\
0.5 & 0.5 \\
1 & 1 \\
2 & 2 \\
3 & 4 \\
4 & 6 \\
6 & 8 \\
8 & 10 \\
10 & 12 \\
12 & 20 \\
20 & 99 \\
- & 3 \\
- & ---
\end{tabular}

\begin{tabular}{|c|c|c|c|}
\hline $\begin{array}{r}\text { Single } \\
\text { Detached }\end{array}$ & $\begin{array}{l}\text { Town- } \\
\text { house }\end{array}$ & $\begin{array}{l}\text { Condo- } \\
\text { Apt. }\end{array}$ & Total \\
\hline $\begin{array}{r}21 \\
119 \\
72 \\
63 \\
44 \\
9 \\
15 \\
16 \\
5 \\
0 \\
0\end{array}$ & $\begin{array}{r}0 \\
0 \\
0 \\
30 \\
0 \\
28 \\
95 \\
0 \\
0 \\
0 \\
0\end{array}$ & $\begin{array}{r}0 \\
0 \\
0 \\
116 \\
0 \\
69 \\
35 \\
0 \\
16 \\
0 \\
0\end{array}$ & $\begin{array}{r}21 \\
119 \\
72 \\
209 \\
44 \\
106 \\
145 \\
16 \\
21 \\
0 \\
0\end{array}$ \\
\hline 364 & 153 & 236 & 753 \\
\hline
\end{tabular}

Percent of units

\begin{tabular}{rr}
\multicolumn{2}{c}{ Density } \\
\hline At & Less \\
\hline Least & Than \\
\hline 0 & 0.5 \\
0.5 & 1 \\
1 & 2 \\
2 & 3 \\
3 & 4 \\
4 & 6 \\
6 & 8 \\
8 & 10 \\
10 & 12 \\
12 & 20 \\
20 & 99 \\
- & 9
\end{tabular}

\begin{tabular}{rrrr}
\multicolumn{4}{c}{ Housing Type } \\
Detached & $\begin{array}{r}\text { Town- } \\
\text { house }\end{array}$ & $\begin{array}{r}\text { Condo- } \\
\text { Apt. }\end{array}$ & Total \\
\hline 5.88 & 0.08 & 0.08 & 2.88 \\
32.78 & 0.08 & 0.08 & 15.88 \\
19.88 & 0.08 & 0.08 & 9.68 \\
17.38 & 19.68 & 49.28 & 27.88 \\
12.18 & 0.08 & 0.08 & 5.88 \\
2.58 & 18.38 & 29.28 & 14.18 \\
4.18 & 62.18 & 14.88 & 19.38 \\
4.48 & 0.08 & 0.08 & 2.18 \\
1.48 & 0.08 & 6.88 & 2.88 \\
0.08 & 0.08 & 0.08 & 0.08 \\
0.08 & 0.08 & 0.08 & 0.08 \\
-0.08 & -0.08 \\
\hline 100.08 & 100.08 & 100.08 & 100.08
\end{tabular}




\section{SQUARE FEET OF FLOOR AREA \\ Medford \\ Number of Data Points}

Floor Area

Square Ft.

\begin{tabular}{|c|c|c|c|c|c|}
\hline $\begin{array}{c}\text { At } \\
\text { Least }\end{array}$ & $\begin{array}{l}\text { Less } \\
\text { Than }\end{array}$ & $\begin{array}{c}\text { Single } \\
\text { Detached }\end{array}$ & $\begin{array}{l}\text { Town- } \\
\text { house }\end{array}$ & $\begin{array}{r}\text { Condo } \\
\text { Apt }\end{array}$ & Total \\
\hline $\begin{array}{r}0 \\
500 \\
750 \\
1,000 \\
1,250 \\
1,500 \\
2,000 \\
2,500 \\
3,000\end{array}$ & $\begin{array}{r}500 \\
750 \\
1,000 \\
1,250 \\
1,500 \\
2,000 \\
2,500 \\
3,000 \\
9,999\end{array}$ & $\begin{array}{r}0 \\
0 \\
0 \\
0 \\
0 \\
2 \\
6 \\
36 \\
74\end{array}$ & $\begin{array}{l}0 \\
0 \\
0 \\
0 \\
0 \\
0 \\
0 \\
0 \\
0\end{array}$ & $\begin{array}{r}0 \\
0 \\
12 \\
23 \\
0 \\
0 \\
0 \\
0 \\
0\end{array}$ & $\begin{array}{r}0 \\
0 \\
12 \\
23 \\
0 \\
2 \\
6 \\
36 \\
74\end{array}$ \\
\hline & & 118 & 0 & 35 & 153 \\
\hline
\end{tabular}

Percent of Units

Floor Area

Square Ft.

Housing Type

\begin{tabular}{|c|c|c|c|c|c|}
\hline $\begin{array}{c}\text { At } \\
\text { Least }\end{array}$ & $\begin{array}{l}\text { Less } \\
\text { Than }\end{array}$ & $\begin{array}{c}\text { Single } \\
\text { Detached }\end{array}$ & $\begin{array}{l}\text { Town- } \\
\text { house }\end{array}$ & $\begin{array}{r}\text { Condo } \\
\text { Apt }\end{array}$ & Total \\
\hline $\begin{array}{r}0 \\
500 \\
750 \\
1,000 \\
1,250 \\
1,500 \\
2,000 \\
2,500 \\
3,000\end{array}$ & $\begin{array}{r}500 \\
750 \\
1,000 \\
1,250 \\
1,500 \\
2,000 \\
2,500 \\
3,000 \\
9,999\end{array}$ & $\begin{array}{r}0.08 \\
0.08 \\
0.08 \\
0.08 \\
0.08 \\
1.78 \\
5.18 \\
30.58 \\
62.78\end{array}$ & $\begin{array}{l}n / a \\
n / a \\
n / a \\
n / a \\
n / a \\
n / a \\
n / a \\
n / a \\
n / a\end{array}$ & $\begin{array}{r}0.08 \\
0.08 \\
34.38 \\
65.78 \\
0.08 \\
0.08 \\
0.08 \\
0.08 \\
0.08\end{array}$ & $\begin{array}{r}0.08 \\
0.08 \\
7.88 \\
15.08 \\
0.08 \\
1.38 \\
3.98 \\
23.58 \\
48.48\end{array}$ \\
\hline Total & & 100.08 & $\mathrm{n} / \mathrm{a}$ & 100.08 & 100.08 \\
\hline
\end{tabular}




\section{SQUARE FEET OF FLOOR AREA \\ Winslow \\ Number of Data Points}

\begin{tabular}{|c|c|c|c|c|c|}
\hline \multicolumn{2}{|c|}{$\begin{array}{l}\text { Floor Area } \\
\text { Square Ft. }\end{array}$} & \multicolumn{3}{|c|}{ Housing Type } & \multirow[b]{2}{*}{ Total } \\
\hline $\begin{array}{r}\text { At } \\
\text { Least }\end{array}$ & $\begin{array}{l}\text { Less } \\
\text { Than }\end{array}$ & $\begin{array}{c}\text { Single } \\
\text { Detached }\end{array}$ & $\begin{array}{l}\text { Town- } \\
\text { house }\end{array}$ & $\begin{array}{r}\text { Condo } \\
\text { Apt }\end{array}$ & \\
\hline $\begin{array}{r}0 \\
500 \\
750 \\
1,000 \\
1,250 \\
1,500 \\
2,000 \\
2,500 \\
3,000\end{array}$ & $\begin{array}{r}500 \\
750 \\
1,000 \\
1,250 \\
1,500 \\
2,000 \\
2,500 \\
3,000 \\
9,999\end{array}$ & $\begin{array}{r}0 \\
34 \\
65 \\
40 \\
4 \\
0 \\
0 \\
0 \\
0\end{array}$ & $\begin{array}{r}0 \\
57 \\
0 \\
0 \\
0 \\
0 \\
0 \\
0 \\
0\end{array}$ & $\begin{array}{l}0 \\
0 \\
0 \\
0 \\
0 \\
0 \\
0 \\
0 \\
0\end{array}$ & $\begin{array}{r}0 \\
91 \\
65 \\
40 \\
4 \\
0 \\
0 \\
0 \\
0\end{array}$ \\
\hline tal & & 143 & 57 & 0 & 200 \\
\hline
\end{tabular}

Percent of Units

Floor Area

Square Ft.

\begin{tabular}{|c|c|c|c|c|c|}
\hline $\begin{array}{r}\text { At } \\
\text { Least }\end{array}$ & $\begin{array}{l}\text { Less } \\
\text { Than }\end{array}$ & $\begin{array}{c}\text { Single } \\
\text { Detached }\end{array}$ & $\begin{array}{l}\text { Town- } \\
\text { house }\end{array}$ & $\begin{array}{r}\text { Condo } \\
\text { Apt }\end{array}$ & Total \\
\hline $\begin{array}{r}0 \\
500 \\
750 \\
1,000 \\
1,250 \\
1,500 \\
2,000 \\
2,500 \\
3,000\end{array}$ & $\begin{array}{r}500 \\
750 \\
1,000 \\
1,250 \\
1,500 \\
2,000 \\
2,500 \\
3,000 \\
9,999\end{array}$ & $\begin{array}{r}0.08 \\
23.88 \\
45.58 \\
28.08 \\
2.88 \\
0.08 \\
0.08 \\
0.08 \\
0.08\end{array}$ & $\begin{array}{r}0.08 \\
100.08 \\
0.08 \\
0.08 \\
0.08 \\
0.08 \\
0.08 \\
0.08 \\
0.08\end{array}$ & $\begin{array}{l}n / a \\
n / a \\
n / a \\
n / a \\
n / a \\
n / a \\
n / a \\
n / a \\
n / a\end{array}$ & $\begin{array}{r}0.08 \\
45.58 \\
32.58 \\
20.08 \\
2.08 \\
0.08 \\
0.08 \\
0.08 \\
0.08\end{array}$ \\
\hline tal & & 100.08 & 100.08 & $n / a$ & 100.08 \\
\hline
\end{tabular}




\section{SQUARE FEET OF FLOOR AREA \\ Galloway}

Number of Data Points

\begin{tabular}{|c|c|c|c|c|c|}
\hline $\begin{array}{c}\text { At } \\
\text { Least }\end{array}$ & $\begin{array}{l}\text { Less } \\
\text { Than }\end{array}$ & $\begin{array}{c}\text { Single } \\
\text { Detached }\end{array}$ & $\begin{array}{l}\text { Town- } \\
\text { house }\end{array}$ & $\begin{array}{r}\text { Condo } \\
\text { Apt }\end{array}$ & Total \\
\hline $\begin{array}{r}0 \\
500 \\
750 \\
1,000 \\
1,250 \\
1,500 \\
2,000 \\
2,500 \\
3,000\end{array}$ & $\begin{array}{r}500 \\
750 \\
1,000 \\
1,250 \\
1,500 \\
2,000 \\
2,500 \\
3,000 \\
9,999\end{array}$ & $\begin{array}{r}0 \\
0 \\
0 \\
6 \\
12 \\
17 \\
2 \\
0 \\
0\end{array}$ & $\begin{array}{r}0 \\
0 \\
0 \\
7 \\
23 \\
0 \\
0 \\
0 \\
0\end{array}$ & $\begin{array}{r}0 \\
0 \\
62 \\
66 \\
5 \\
0 \\
0 \\
0 \\
0\end{array}$ & $\begin{array}{r}0 \\
0 \\
62 \\
79 \\
40 \\
17 \\
2 \\
0 \\
0\end{array}$ \\
\hline al & & 37 & 30 & 133 & 200 \\
\hline
\end{tabular}

Percent of Units

Floor Area

Square Ft.

\begin{tabular}{|c|c|c|c|c|c|}
\hline $\begin{array}{r}\text { At } \\
\text { Least }\end{array}$ & $\begin{array}{l}\text { Less } \\
\text { Than }\end{array}$ & $\begin{array}{c}\text { Single } \\
\text { Detached }\end{array}$ & $\begin{array}{l}\text { Town- } \\
\text { house }\end{array}$ & $\begin{array}{r}\text { Condo } \\
\text { Apt }\end{array}$ & Total \\
\hline $\begin{array}{r}0 \\
500 \\
750 \\
1,000 \\
1,250 \\
1,500 \\
2,000 \\
2,500 \\
3,000\end{array}$ & $\begin{array}{r}500 \\
750 \\
1,000 \\
1,250 \\
1,500 \\
2,000 \\
2,500 \\
3,000 \\
9,999\end{array}$ & $\begin{array}{r}0.08 \\
0.08 \\
0.08 \\
16.28 \\
32.48 \\
45.98 \\
5.48 \\
0.08 \\
0.08\end{array}$ & $\begin{array}{r}0.08 \\
0.08 \\
0.08 \\
23.38 \\
76.78 \\
0.08 \\
0.08 \\
0.08 \\
0.08\end{array}$ & $\begin{array}{r}0.08 \\
0.08 \\
46.68 \\
49.68 \\
3.88 \\
0.08 \\
0.08 \\
0.08 \\
0.08\end{array}$ & $\begin{array}{r}0.08 \\
0.08 \\
31.08 \\
39.58 \\
20.08 \\
8.58 \\
1.08 \\
0.08 \\
0.08\end{array}$ \\
\hline & & 100.08 & 100.08 & 100.08 & 100.08 \\
\hline
\end{tabular}




\section{SQUARE FEET OF FLOOR AREA Jackson}

Number of Data Points

Floor Area

Square Ft.

\begin{tabular}{rrrrrr} 
At & Less & Single & Town & Condo & \\
Least & Than & Detached & house & Apt & Total \\
\hline 0 & 500 & 0 & 0 & 0 & 0 \\
500 & 750 & 0 & 0 & 0 & 0 \\
750 & 1,000 & 0 & 0 & 45 & 45 \\
1,000 & 1,250 & 6 & 32 & 8 & 46 \\
1,250 & 1,500 & 4 & 21 & 15 & 40 \\
1,500 & 2,000 & 17 & 13 & 0 & 30 \\
2,000 & 2,500 & 34 & 0 & 0 & 34 \\
2,500 & 3,000 & 5 & 0 & 0 & 5 \\
3,000 & 9,999 & 0 & 0 & 0 & 0 \\
-00 & & 66 & 66 & 68 & 200
\end{tabular}

Percent of Units

\begin{tabular}{|c|c|c|c|c|c|}
\hline $\begin{array}{c}\text { At } \\
\text { Least }\end{array}$ & $\begin{array}{l}\text { Less } \\
\text { Than }\end{array}$ & $\begin{array}{c}\text { Single } \\
\text { Detached }\end{array}$ & $\begin{array}{l}\text { Town- } \\
\text { house }\end{array}$ & $\begin{array}{r}\text { Condo } \\
\text { Apt }\end{array}$ & Total \\
\hline $\begin{array}{r}0 \\
500 \\
750 \\
1,000 \\
1,250 \\
1,500 \\
2,000 \\
2,500 \\
3,000\end{array}$ & $\begin{array}{r}500 \\
750 \\
1,000 \\
1,250 \\
1,500 \\
2,000 \\
2,500 \\
3,000 \\
9,999\end{array}$ & $\begin{array}{r}0.08 \\
0.08 \\
0.08 \\
9.18 \\
6.18 \\
25.88 \\
51.58 \\
7.68 \\
0.08\end{array}$ & $\begin{array}{r}0.08 \\
0.08 \\
0.08 \\
48.58 \\
31.88 \\
19.78 \\
0.08 \\
0.08 \\
0.08\end{array}$ & $\begin{array}{r}0.08 \\
0.08 \\
66.28 \\
11.88 \\
22.18 \\
0.08 \\
0.08 \\
0.08 \\
0.08\end{array}$ & $\begin{array}{r}0.08 \\
0.08 \\
22.58 \\
23.08 \\
20.08 \\
15.08 \\
17.08 \\
2.58 \\
0.08\end{array}$ \\
\hline al & & 100.08 & 100.08 & 100.08 & 100.08 \\
\hline
\end{tabular}


SQUARE FEET OF FLOOR AREA

Unweighted Total

Number of Data Points

Floor Area

\begin{tabular}{|c|c|c|c|c|c|}
\hline $\begin{array}{c}\text { At } \\
\text { Least }\end{array}$ & $\begin{array}{l}\text { Less } \\
\text { Than }\end{array}$ & $\begin{array}{c}\text { Single } \\
\text { Detached }\end{array}$ & $\begin{array}{l}\text { Town- } \\
\text { house }\end{array}$ & $\begin{array}{r}\text { Condo } \\
\text { Apt }\end{array}$ & Total \\
\hline $\begin{array}{r}0 \\
500 \\
750 \\
1,000 \\
1,250 \\
1,500 \\
2,000 \\
2,500 \\
3,000\end{array}$ & $\begin{array}{r}500 \\
750 \\
1,000 \\
1,250 \\
1,500 \\
2,000 \\
2,500 \\
3,000 \\
9,999\end{array}$ & $\begin{array}{l}0 \\
34 \\
65 \\
52 \\
20 \\
36 \\
42 \\
41 \\
74\end{array}$ & $\begin{array}{r}0 \\
57 \\
0 \\
39 \\
44 \\
13 \\
0 \\
0 \\
0\end{array}$ & $\begin{array}{r}0 \\
0 \\
119 \\
97 \\
20 \\
0 \\
0 \\
0 \\
0\end{array}$ & $\begin{array}{r}0 \\
91 \\
184 \\
188 \\
84 \\
49 \\
42 \\
41 \\
74\end{array}$ \\
\hline & & 364 & 153 & 236 & 753 \\
\hline
\end{tabular}

Percent of Units

Floor Area

Square Ft.

\begin{tabular}{|c|c|c|c|c|c|}
\hline $\begin{array}{r}\text { At } \\
\text { Least }\end{array}$ & $\begin{array}{l}\text { Less } \\
\text { Than }\end{array}$ & $\begin{array}{c}\text { Single } \\
\text { Detached }\end{array}$ & $\begin{array}{l}\text { Town- } \\
\text { house }\end{array}$ & $\begin{array}{r}\text { Condo } \\
\text { Apt }\end{array}$ & Total \\
\hline $\begin{array}{r}0 \\
500 \\
750 \\
1,000 \\
1,250 \\
1,500 \\
2,000 \\
2,500 \\
3,000\end{array}$ & $\begin{array}{r}500 \\
750 \\
1,000 \\
1,250 \\
1,500 \\
2,000 \\
2,500 \\
3,000 \\
9,999\end{array}$ & $\begin{array}{r}0.08 \\
9.38 \\
17.98 \\
14.38 \\
5.58 \\
9.98 \\
11.58 \\
11.38 \\
20.38\end{array}$ & $\begin{array}{r}0.08 \\
37.38 \\
0.08 \\
25.58 \\
28.88 \\
8.58 \\
0.08 \\
0.08 \\
0.08\end{array}$ & $\begin{array}{r}0.08 \\
0.08 \\
50.48 \\
41.18 \\
8.58 \\
0.08 \\
0.08 \\
0.08 \\
0.08\end{array}$ & $\begin{array}{r}0.08 \\
12.18 \\
24.48 \\
25.08 \\
11.28 \\
6.58 \\
5.68 \\
5.48 \\
9.88\end{array}$ \\
\hline otal & & 100.08 & 100.08 & 100.08 & 100.08 \\
\hline
\end{tabular}

APPENDIX C Page 10 


\section{PRICE \\ Medford}

Number of Data Points

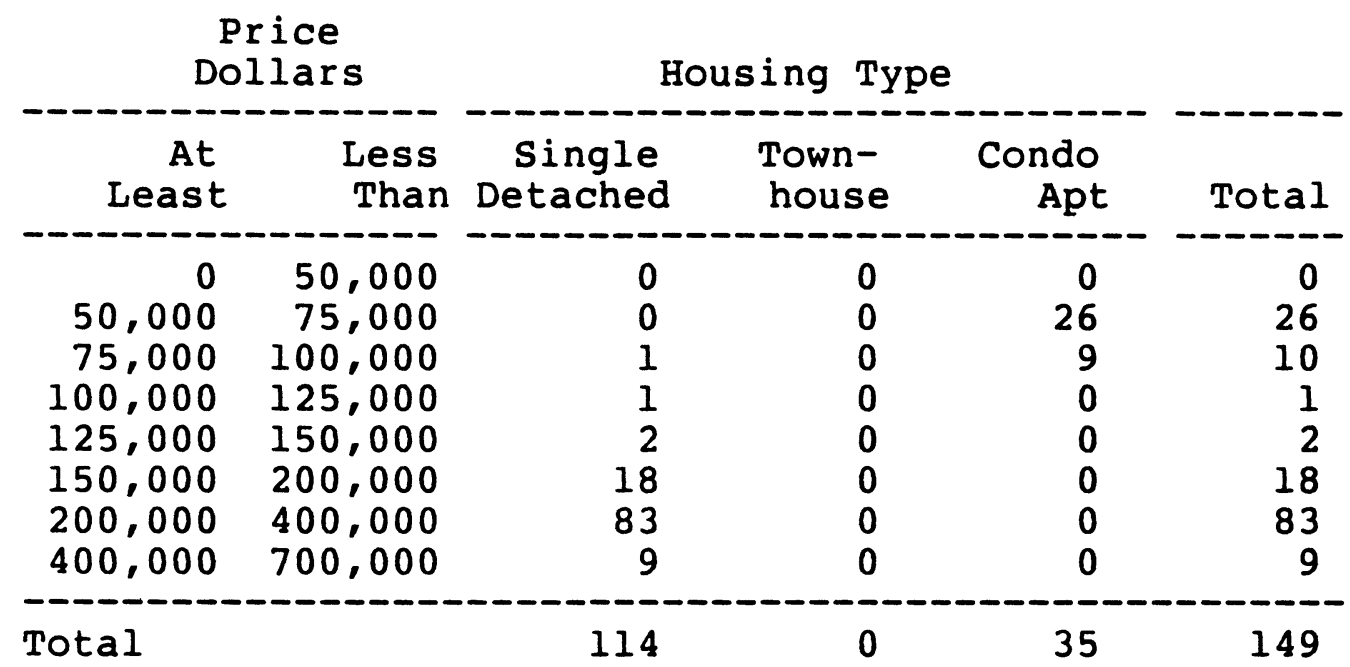

Percent of Units

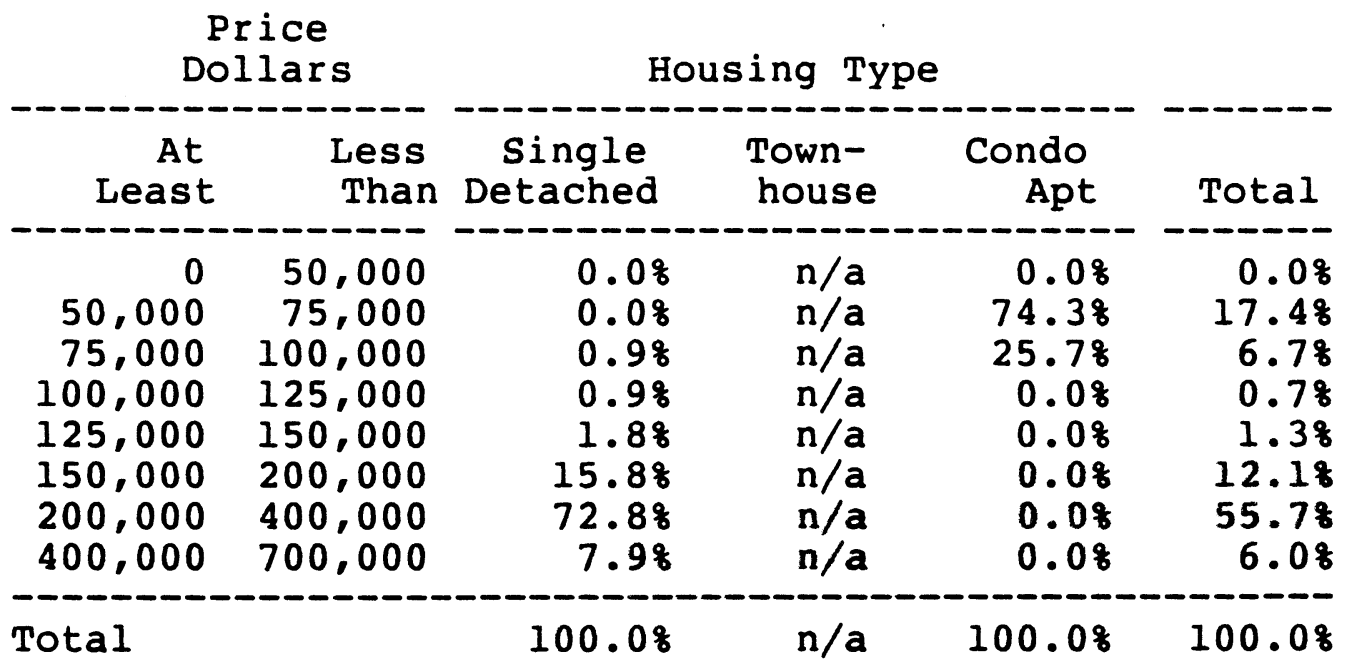


PRICE

Winslow

Number of Data Points

\begin{tabular}{|c|c|c|c|c|c|}
\hline \multicolumn{2}{|c|}{$\begin{array}{l}\text { Price } \\
\text { Dollars }\end{array}$} & \multicolumn{3}{|c|}{ Housing Type } & \\
\hline $\begin{array}{c}\text { At } \\
\text { Least }\end{array}$ & $\begin{array}{l}\text { Less } \\
\text { Than }\end{array}$ & $\begin{array}{c}\text { Single } \\
\text { Detached }\end{array}$ & $\begin{array}{l}\text { Town- } \\
\text { house }\end{array}$ & $\begin{array}{r}\text { Condo } \\
\text { Apt }\end{array}$ & Total \\
\hline $\begin{array}{r}0 \\
50,000 \\
75,000 \\
100,000 \\
125,000 \\
150,000 \\
200,000 \\
400,000\end{array}$ & $\begin{array}{r}50,000 \\
75,000 \\
100,000 \\
125,000 \\
150,000 \\
200,000 \\
400,000 \\
700,000\end{array}$ & $\begin{array}{r}0 \\
35 \\
86 \\
20 \\
2 \\
0 \\
0 \\
0\end{array}$ & $\begin{array}{r}0 \\
51 \\
6 \\
0 \\
0 \\
0 \\
0 \\
0\end{array}$ & $\begin{array}{l}0 \\
0 \\
0 \\
0 \\
0 \\
0 \\
0 \\
0\end{array}$ & $\begin{array}{r}0 \\
86 \\
92 \\
20 \\
2 \\
0 \\
0 \\
0\end{array}$ \\
\hline Total & & 143 & 57 & 0 & 200 \\
\hline
\end{tabular}

Percent of Units

\begin{tabular}{|c|c|c|c|c|c|}
\hline \multicolumn{2}{|c|}{$\begin{array}{l}\text { Price } \\
\text { Dollars }\end{array}$} & \multicolumn{3}{|c|}{ Housing Type } & \multirow{2}{*}{ Total } \\
\hline $\begin{array}{c}\text { At } \\
\text { Least }\end{array}$ & $\begin{array}{l}\text { Less } \\
\text { Than }\end{array}$ & $\begin{array}{c}\text { Single } \\
\text { Detached }\end{array}$ & $\begin{array}{l}\text { Town- } \\
\text { house }\end{array}$ & $\begin{array}{r}\text { Condo } \\
\text { Apt }\end{array}$ & \\
\hline $\begin{array}{r}0 \\
50,000 \\
75,000 \\
100,000 \\
125,000 \\
150,000 \\
200,000 \\
400,000\end{array}$ & $\begin{array}{r}50,000 \\
75,000 \\
100,000 \\
125,000 \\
150,000 \\
200,000 \\
400,000 \\
700,000\end{array}$ & $\begin{array}{r}0.08 \\
24.58 \\
60.18 \\
14.08 \\
1.48 \\
0.08 \\
0.08 \\
0.08\end{array}$ & $\begin{array}{r}0.08 \\
89.58 \\
10.58 \\
0.08 \\
0.08 \\
0.08 \\
0.08 \\
0.08\end{array}$ & $\begin{array}{l}n / a \\
n / a \\
n / a \\
n / a \\
n / a \\
n / a \\
n / a \\
n / a\end{array}$ & $\begin{array}{r}0.08 \\
43.08 \\
46.08 \\
10.08 \\
1.08 \\
0.08 \\
0.08 \\
0.08\end{array}$ \\
\hline Total & & 100.08 & 100.08 & $\mathrm{n} / \mathrm{a}$ & $100.0 \%$ \\
\hline
\end{tabular}


PRICE

Galloway

Number of Data Points

\begin{tabular}{|c|c|c|c|c|c|}
\hline \multicolumn{2}{|c|}{$\begin{array}{c}\text { Price } \\
\text { Dollars }\end{array}$} & \multicolumn{3}{|c|}{ Housing Type } & \\
\hline $\begin{array}{c}\text { At } \\
\text { Least }\end{array}$ & $\begin{array}{l}\text { Less } \\
\text { Than }\end{array}$ & $\begin{array}{c}\text { Single } \\
\text { Detached }\end{array}$ & $\begin{array}{l}\text { Town- } \\
\text { house }\end{array}$ & $\begin{array}{r}\text { Condo } \\
\text { Apt }\end{array}$ & Total \\
\hline $\begin{array}{r}0 \\
50,000 \\
75,000 \\
100,000 \\
125,000 \\
150,000 \\
200,000 \\
400,000\end{array}$ & $\begin{array}{r}50,000 \\
75,000 \\
100,000 \\
125,000 \\
150,000 \\
200,000 \\
400,000 \\
700,000\end{array}$ & $\begin{array}{r}0 \\
2 \\
17 \\
14 \\
4 \\
0 \\
0 \\
0\end{array}$ & $\begin{array}{r}0 \\
19 \\
11 \\
0 \\
0 \\
0 \\
0 \\
0\end{array}$ & $\begin{array}{r}0 \\
116 \\
17 \\
0 \\
0 \\
0 \\
0 \\
0\end{array}$ & $\begin{array}{r}0 \\
137 \\
45 \\
14 \\
4 \\
0 \\
0 \\
0\end{array}$ \\
\hline Total & & 37 & 30 & 133 & 200 \\
\hline
\end{tabular}

Percent of Units

\begin{tabular}{|c|c|c|c|c|c|}
\hline \multicolumn{2}{|c|}{$\begin{array}{c}\text { Price } \\
\text { Dollars }\end{array}$} & \multicolumn{3}{|c|}{ Housing Type } & \multirow[b]{2}{*}{ Total } \\
\hline $\begin{array}{r}\text { At } \\
\text { Least }\end{array}$ & $\begin{array}{l}\text { Less } \\
\text { Than }\end{array}$ & $\begin{array}{c}\text { Single } \\
\text { Detached }\end{array}$ & $\begin{array}{l}\text { Town- } \\
\text { house }\end{array}$ & $\begin{array}{r}\text { Condo } \\
\text { Apt }\end{array}$ & \\
\hline $\begin{array}{r}0 \\
50,000 \\
75,000 \\
100,000 \\
125,000 \\
150,000 \\
200,000 \\
400,000\end{array}$ & $\begin{array}{r}50,000 \\
75,000 \\
100,000 \\
125,000 \\
150,000 \\
200,000 \\
400,000 \\
700,000\end{array}$ & $\begin{array}{r}0.08 \\
5.48 \\
45.98 \\
37.88 \\
10.88 \\
0.08 \\
0.08 \\
0.08\end{array}$ & $\begin{array}{r}0.08 \\
63.38 \\
36.78 \\
0.08 \\
0.08 \\
0.08 \\
0.08 \\
0.08\end{array}$ & $\begin{array}{r}0.08 \\
87.28 \\
12.88 \\
0.08 \\
0.08 \\
0.08 \\
0.08 \\
0.08\end{array}$ & $\begin{array}{r}0.08 \\
68.58 \\
22.58 \\
7.08 \\
2.08 \\
0.08 \\
0.08 \\
0.08\end{array}$ \\
\hline Total & & 100.08 & $100.0 \%$ & 100.08 & 100.08 \\
\hline
\end{tabular}




\begin{tabular}{|c|c|c|c|c|c|}
\hline \multicolumn{6}{|c|}{$\begin{array}{c}\text { PRICE } \\
\text { Jackson }\end{array}$} \\
\hline \multicolumn{6}{|c|}{ Number of } \\
\hline \multicolumn{2}{|c|}{$\begin{array}{l}\text { Price } \\
\text { Dollars }\end{array}$} & \multicolumn{3}{|c|}{ Housing Type } & \\
\hline $\begin{array}{l}\text { At } \\
\text { Least }\end{array}$ & $\begin{array}{l}\text { Less } \\
\text { Than }\end{array}$ & $\begin{array}{c}\text { Single } \\
\text { Detached }\end{array}$ & $\begin{array}{l}\text { Town- } \\
\text { house }\end{array}$ & $\begin{array}{l}\text { Condo } \\
\text { Apt }\end{array}$ & Total \\
\hline $\begin{array}{r}0 \\
50,000 \\
75,000 \\
100,000 \\
125,000 \\
150,000 \\
200,000 \\
400,000\end{array}$ & $\begin{array}{r}50,000 \\
75,000 \\
100,000 \\
125,000 \\
150,000 \\
200,000 \\
400,000 \\
700,000\end{array}$ & $\begin{array}{r}0 \\
1 \\
4 \\
9 \\
21 \\
27 \\
4 \\
0\end{array}$ & $\begin{array}{r}0 \\
6 \\
39 \\
21 \\
0 \\
0 \\
0 \\
0\end{array}$ & $\begin{array}{r}0 \\
15 \\
50 \\
3 \\
0 \\
0 \\
0 \\
0\end{array}$ & $\begin{array}{r}0 \\
22 \\
93 \\
33 \\
21 \\
27 \\
4 \\
0\end{array}$ \\
\hline rotal & & 66 & 66 & 68 & 200 \\
\hline
\end{tabular}

Percent of Units

\begin{tabular}{|c|c|c|c|c|c|}
\hline $\begin{array}{c}\text { At } \\
\text { Least }\end{array}$ & $\begin{array}{l}\text { Less } \\
\text { Than }\end{array}$ & $\begin{array}{c}\text { Single } \\
\text { Detached }\end{array}$ & $\begin{array}{l}\text { Town- } \\
\text { house }\end{array}$ & $\begin{array}{r}\text { Condo } \\
\text { Apt }\end{array}$ & Total \\
\hline $\begin{array}{r}0 \\
50,000 \\
75,000 \\
100,000 \\
125,000 \\
150,000 \\
200,000 \\
400,000\end{array}$ & $\begin{array}{r}50,000 \\
75,000 \\
100,000 \\
125,000 \\
150,000 \\
200,000 \\
400,000 \\
700,000\end{array}$ & $\begin{array}{r}0.08 \\
1.58 \\
6.18 \\
13.68 \\
31.88 \\
40.98 \\
6.118 \\
0.08\end{array}$ & $\begin{array}{r}0.08 \\
9.18 \\
59.18 \\
31.88 \\
0.08 \\
0.08 \\
0.08 \\
0.08\end{array}$ & $\begin{array}{r}0.08 \\
22.18 \\
73.58 \\
4.48 \\
0.08 \\
0.08 \\
0.08 \\
0.08\end{array}$ & $\begin{array}{l}0 . \\
11 . \\
46 . \\
16 . \\
10 . \\
13 .\end{array}$ \\
\hline otal & & 100.08 & 100.08 & 100.08 & 100 \\
\hline
\end{tabular}


PRICE

Unweighted Total

Number of Data Points

\begin{tabular}{|c|c|c|c|c|c|}
\hline \multicolumn{2}{|c|}{$\begin{array}{c}\text { Price } \\
\text { Dollars }\end{array}$} & \multicolumn{3}{|c|}{ Housing Type } & \multirow{2}{*}{ Total } \\
\hline $\begin{array}{r}\text { At } \\
\text { Least }\end{array}$ & $\begin{array}{l}\text { Less } \\
\text { Than }\end{array}$ & $\begin{array}{c}\text { Single } \\
\text { Detached }\end{array}$ & $\begin{array}{l}\text { Town- } \\
\text { house }\end{array}$ & $\begin{array}{r}\text { Condo } \\
\text { Apt }\end{array}$ & \\
\hline $\begin{array}{r}0 \\
50,000 \\
75,000 \\
100,000 \\
125,000 \\
150,000 \\
200,000 \\
400,000\end{array}$ & $\begin{array}{r}50,000 \\
75,000 \\
100,000 \\
125,000 \\
150,000 \\
200,000 \\
400,000 \\
700,000\end{array}$ & $\begin{array}{r}0 \\
38 \\
108 \\
44 \\
29 \\
45 \\
87 \\
9\end{array}$ & $\begin{array}{r}0 \\
76 \\
56 \\
21 \\
0 \\
0 \\
0 \\
0\end{array}$ & $\begin{array}{r}0 \\
157 \\
76 \\
3 \\
0 \\
0 \\
0 \\
0\end{array}$ & $\begin{array}{r}0 \\
271 \\
240 \\
68 \\
29 \\
45 \\
87 \\
9\end{array}$ \\
\hline rotal & & 360 & 153 & 236 & 749 \\
\hline
\end{tabular}

Percent of Units

Price

Dollars

\begin{tabular}{rrrrrr} 
At & Less & Single & Town- & Condo \\
Least & Than & Detached & house & Apt & Total \\
\hline 0 & 50,000 & 0.08 & 0.08 & 0.08 & 0.08 \\
50,000 & 75,000 & 10.68 & 49.78 & 66.58 & 36.28 \\
75,000 & 100,000 & 30.08 & 36.68 & 32.28 & 32.08 \\
100,000 & 125,000 & 12.28 & 13.78 & 1.38 & 9.18 \\
125,000 & 150,000 & 8.18 & 0.08 & 0.08 & 3.98 \\
150,000 & 200,000 & 12.58 & 0.08 & 0.08 & 6.08 \\
200,000 & 400,000 & 24.28 & 0.08 & 0.08 & 11.68 \\
400,000 & 700,000 & 2.58 & 0.08 & 0.08 & 1.28 \\
\hline-900 & & 100.08 & 100.08 & 100.08 & 100.08
\end{tabular}


APPENDIX D.

Economic Analysis of Pinelands Development Credits 


\section{OCT 27 VON}

\section{THE PINELANDS DEVELOPMENT CREDIT}

The Pinelands Development Credit (PDC) was incorporated into the Pinelands Comprehensive Development Management Plan (Pinelands Plan) as a means to ameliorate, at least partially if not wholly, the economic dislocations expected to result from implementation of the Pinelands Plan. The PDC is a Transferable Development Right (TDR). The TDR was put forward to ameliorate the "windfalls" and "wipeouts" which may accompany significant changes in land use policy.

A TDR program accomplishes redistribution by requiring property owners wishing to increase intensity in the areas designated for growth to acquire the development rights from properties designated for preservation. It is presumed that this possession would be accomplished by developers in growth areas purchasing development rights from property owners in areas designated for limited development. As a TDR program, the PDC requires the acquisition of development rights from properties within the various areas designated for limited development as a condition for increased intensity within regional growth districts.

The PDC program was initially established in 1980. However, it would have been impossible to use PDC until several years later. The municipalities within the Pinelands had to adjust their land development regulations to accommodate PDCs. Moreover, the PDC program was subjected to litigation which struck at the 
heart of the program in that little confidence could be held in a program which might be tossed out by the courts. Perhaps the most important delay encountered by the PDC program was the significant recession of the early 1980's and the particularly severe effects of this recession on real estate and construction. At this time the lawsuits have been disposed of and the nation has been enjoying a lengthily period of prosperity. It is appropriate to review the PDC program in order to determine whether it has accomplished its objectives and what changes could be made to enhance the effectiveness of the PDC. This report is part of that review. 
II. SCOPE OF THIS REPORT

This report deals with the potentials for use of PDCs. Given that PDCs are used to increase development intensity in growth areas, the value of PDCs would be a derivative of the value of increased intensity. The basic premise of all TDR programs is that there is a general market tendency toward increased intensity (i.e., density per acre) of land development. Given this premise, it would follow that land value is, in part, a function of the permitted density of development. Mathematically, this is expressed:

$$
L V=f(D E N)
$$

where

$$
\begin{aligned}
& \mathrm{LV}=\text { land value per acre } \\
& \mathrm{DEN}=\text { permitted density per acre } \\
& \mathrm{f} \text { - represents an unspecified relationship. }
\end{aligned}
$$

Given the above, any change in DEN should result in a change in LV, or

$$
\mathrm{dLV} / \mathrm{dDEN}>0.1
$$

However, various studies and experience have shown that there are many circumstances where land value is invariant with respect to changes in density. There are several reasons for such occurrences. The first, and most significant, is when land is already permitted a density which is at or above what the market would dictate. In such situations, further increases in density would not affect land value, or

1 In this expression the d indicates or expresses a change in. Appendix D Page 3 


$$
\mathrm{dLV} / \mathrm{dDEN}=0 .
$$

Another situation where land value would be invariant with respect to density would be where the other development regulations, such as height restrictions or setbacks, preclude increased density even if the market would accept such increases. One of the common reasons for lowered density is the lack (or cost) of central water and sewers. Low density allows the use of wells or septic tanks. Thus, the lack of such facilities can negate a general market tendency toward increased density.

This inquiry looks to market transactions in and around the Pinelands in order to provide some specification of the value of increased density. of necessity, this analysis does not inquire into the second and third matters indicated above. Rather, the objective here is to determine the economic value of increased density, and based upon this determination, to project an estimate of the economic value of a PDC.

In order to accomplish the objective set out above, a total of 753 market transactions involving residential properties were analyzed. These sales took place in 27 identifiable sub-markets, or neighborhoods. The sample size was randomly reduced to 699 in order to fit the memory limitations of the statistical program. For each of the transactions, data were collected that would provide a basis to statistically generalize to the PDC. Additionally, lot sizes for single family homes were adjusted to arrive at a density of development that is comparable with the 
gross density data for multi-family developments. These data are:

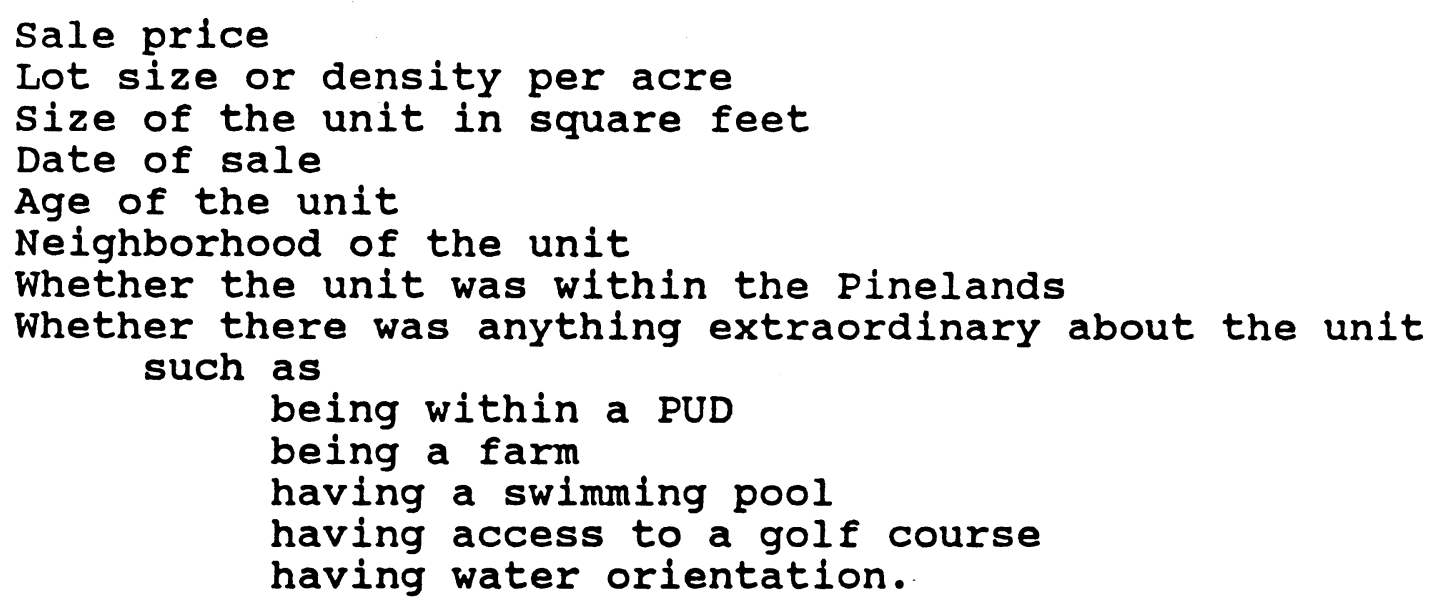

Any property identified as an active farm was excluded from the analysis because the value of the farming enterprise might enter the market price of the property. It is presumed that each of the remaining factors could have an influence on sale price. Thus, these data were collected so that regression analysis could control for such factors. For example, it would be expected that a home with a swimming pool would, all other things equal, command a higher price than a home without a pool. Failure to incorporate such factors into the analysis could result in significant errors.

These data yield the following means:

Density per acre

Square feet in unit

Sale price

Percent in PUD

Percent farms

Percent with pool
7.171

1,466

$\$ 112,302$

$52 \%$

$1.5 \%$

$2.3 \%$

The analysis of these data was done by multiple regression. This statistical method measures the significance of co-variance Appendix D Page 5 
among 2 or more variables. One variable is designated the dependent variable and the others are the independent variables. It is presumed that the independent variables exert some causal influence on the magnitude of the independent variable. For most of the analyses, the dependent variable is sale price. Thus, it is presumed that each of the data series listed above may influence sale price. The exact set of hypotheses are:

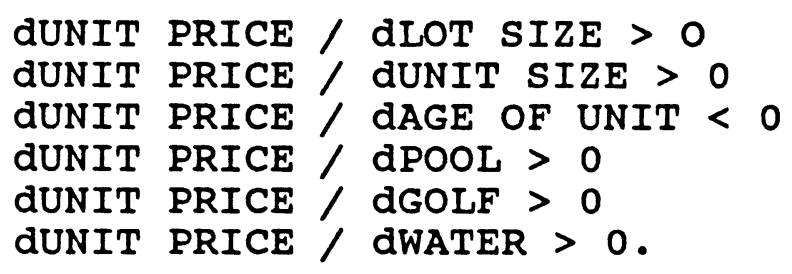

There were no set hypotheses with respect to location in individual neighborhoods, location within the Pinelands, and being within a Planned Unit Development. Rather, these data were analyzed to determine if there is significant variation in sales price between PUD and non-PUD, among individual neighborhoods, and between the area within the Pinelands and that outside of the Pinelands.

Multiple regression measures the degree of co-variation among the data series. It provides results in the form of statistics. The basic form of a multiple regression equation is:

$$
\mathrm{DEP}=\mathrm{A}+\mathrm{b}_{1} \mathrm{x}_{1}+\mathrm{b}_{2} \mathrm{x}_{2}+\ldots+\mathrm{b}_{\mathrm{n}} \mathrm{x}_{\mathrm{n}}
$$

DEP is the value of the independent variable, usually sales price. $A$ is the intercept and reflects the autonomous sales value of a home, or that value that would exist if none of the explanatory variables were present. The Xs are the independent variables. 
The coefficient $b$ expresses how the value of DEP varies with the value of $x$. So, if $b$ were to equal .5 , it would mean that for each change of 1 in the value of $X$, DEP would change by .5. The entire equation and each of the individual items within the equation are tested for statistical significance. The important statistics are:

$R$ - the coefficient of determination. This measures the degree of determination between the independent variables and the dependent variables and is expressed as a decimal. The highest possible value is 1 and the lowest is 0 . The closer to 1 , the higher the degree of co-variation and thus the higher the degree of explanatory power or ability of the regression equation. For the purposes of this analysis, values of $R$ greater than .50 will be accepted as having high statistical significance. However, values as low as .25 can be accepted.

$T$ or T-Ratio. This statistic, shown above each b, measures the significance of the individual b. The $\mathrm{T}$ - Ratio indicates whether that particular $X$ has any significance in the variation of DEP. Generally, the $\mathrm{T}$ - Ratio must be 2 or greater before it may be accepted that the particular $\mathrm{x}$ has a significant relationship with the DEP. The sign of $T$ is of no importance.

Beta statistic - a measure of relative importance of an individual $x$ in the total variation of DEP. The highest value of Beta among all of the values of Beta shows which of the individual data services is the strongest predictor of the value of DEP. The lowest value of Beta shows which is the weakest predictor.

F statistic. This is a measurement of the statistical significance of the entire equation. It is similar to the T-Ratio except it measures the significance of the entire equation rather than the individual coefficient (b). For this analysis, a value of $F$ in excess of 5 will indicate acceptable significance.

This type of statistical analysis involves two elements. One is the statistical analysis of the various measures discussed above. The other, and perhaps more important, is the use of what is Appendix D Page 7 
generally considered to be common sense. The several relation ships to be subjected to statistical analysis must first make sense before any statistical conclusion has meaning.

The basic thesis of this inquiry is that land value will tend to increase with an increase in permitted density. This general principle is in accord with common sense and experience. The objective is the estimate how much land value will rise, per acre and per unit, with increased density within the areas of jurisdiction of the pinelands commission. The attainment of this objective requires that there be an acceptable description of the important factors in the setting of sale prices. The factors utilized herein have been set out above. These factors incorporate the nature and amenities of the individual unit and the location of that unit. These are usually considered to be the primary determinants of price. It is put forward here that this approach is in accord with common sense and attention may now be turned to statistical measurements.

Appendix D Page 8 
IV. RESULTS

In this analysis, the following variables are used:

$P$ - estimated market price of a dwelling unit

A - the intercept term estimated by the equation

DEN - size of the lot or parcel in units per acre

FT - square fee of the dwelling unit

PUD - a dummy variable $(0,1)$ reflecting whether the unit is within a Planned Unit Development

POOL - a dummy variable $(0,1)$ reflecting whether the unit has a recreational area featuring a swimming pool

GOLF - a dummy variable $(0,1)$ reflecting whether the unit has access to a golf course

WATER - a dummy variable $(0,1)$ reflecting whether the unit has some water orientation

$b(1)$ - the coefficient of DEN

$b(2)$ - the coefficient of FT

$b(3)$ - the coefficient of PUD

$b(4)$ - the coefficient of POOL

$b(5)$ - the coefficient of GOLF

$b(6)$ - the coefficient of WATER

The full equation to be tested is:

$$
\begin{aligned}
P=A+ & b(1) * D E N+b(2) * F T+b(3) * P U D+b(4) * P O O L \\
& +b(5) * \text { GOLF }+b(6) * \text { WATER }
\end{aligned}
$$

The results of this equation are:

$$
\begin{aligned}
& (5.9)^{2} \quad(46.3) \quad(9.0) \\
& \mathrm{P}=13246+1240 * \mathrm{DEN}+69.8 * \mathrm{FT}-24878 * \mathrm{PUD}+50873 * \mathrm{POOL} \\
& (9.0) \\
& +179831 * \text { GOLF + 140639*WATER } \\
& \mathrm{R}=.8666 \\
& F=754 .
\end{aligned}
$$

This equation is highly significant, 1.e., it has a high degree of explanatory power. However, this form of the equation will not be used. Rather, it simply demonstrates the basic soundness of the logic.

This equation was converted to (natural) logarithms for the

2 These numbers above the coefficients are the T-Ratios

$$
\text { Appendix D Page } 9
$$


analysis. This conversion was made because the premise is that changes in DEN and FT will result in proportionate changes in $P$. Natural logarithms are the preferred method of analysis of change. Thus, all expressions result from the analysis of log formulations. The results have been converted back to the linear form for ease of presentation. Moreover, PUD, POOL, GOLF, and WATER were aggregated into a single variable, AMENITY, for this analysis. The result of this equation is:

$$
\begin{gathered}
\log P=6.83091-.056683 \text { LOgDEN }+.6752 \text { LOgFT }-.1449 \text { AMENITY } \\
R=.8185 \quad F=1046 .
\end{gathered}
$$

The Beta Coefficients are:

$$
\begin{array}{lll}
\text { DEN } & -- & .1296 \\
\text { FT } & -- & .7204 \\
\text { AMENITY } & -- & .1477
\end{array}
$$

These coefficients indicate that the most important factor in determining the price of a dwelling is the size of the unit in square feet.

An interesting observation is that AMENITY appears to have a negative effect on price. However, this is not the case. Rather, AMENITY works in conjunction with DENSITY. As density increases, price falls. However, there is a partial restoration of price as a consequence of the amenity. The net effect of density and amenity is positive.

The objective of this study is to establish a basis for estimating the economic value of increased density. This is done using the following equations:

$$
\text { Appendix D Page } 10
$$




$$
\begin{array}{cc}
\text { AMENITY }=.076288254+.312074 * \text { LOgDEN } \\
R=.4895 \quad F=668,
\end{array}
$$

and

$$
\begin{array}{rrr}
F T= & (17.5) \\
R= & =.3055 & F=307.61-73.88 * \mathrm{DEN}
\end{array}
$$

These equations estimate the size of the units and the amenity package as a function of density. Once estimated, the values of AMENITY and FT are used to simulate the economics of increased density.

Whether an individual wished to increase density primarily would be a matter of whether a profit would result. The above equations will estimate the additional revenues from increasing density. Profit, however, is a matter of revenues less costs. Thus, costs must be introduced. The cost parameters utilized are:

$\begin{array}{cc}\text { LAND COST; } & \\ \text { PER PARCEL } & 25,000 \\ \text { PER ACRE } & 5,000 \\ \text { PER DEN } & 500 \\ \text { LAND DEVELOPMENT; } & \\ \text { PER ACRE } & 2,000 \\ \text { PER UNIT } & 1,500 \text { FOR ALL UNITS } \\ \text { PLUS } & 50,000 \text { FIXED COST } \\ \text { AMENITY } & 12,500 \text { PER UNIT } \\ \text { CONSTRUCTION PER FT } & \\ \text { PER FT } & 42.25 \text { BASE COST } \\ \text { PER DEN } & -0.32 \text { PER FT } \\ \text { SELLING COSTS } & 7.08 \text { OF TOTAL RECEIPTS } \\ \text { INDIRECT COST } & 25.08 \text { OF DIRECT } \\ \text { PRIME RATE } & 9.58 \\ \text { PARCEL SIZE } & 50 \text { ACRES }\end{array}$


These data have a variety of sources. Land value is based upon a large number of appraisals and other data in the files of the Pinelands Commission. However, the actual number is based upon the judgment of the author. It is extremely difficult to utilize a single base number as representative of property within an area as large as the Pinelands. However, the PDC program will be in effect over that area. The base figure represents property (raw land) restricted to 5 acre lots or larger. Base land value in increased by $10 \%$ for each unit of density per acre. So, land permitted for 10 units per acre would command $\$ 10,000$ in its undeveloped (raw) state.

As with land, the cost of development. is based upon a variety of sources. Most of these are taken from developer submissions to the Pinelands Commission. However, cost Effective Land Development (National Association of Homebuilders, 19--) and Residential Development Handbook (Washington: Urban Land Institute 1978) were referred to. However, the final costs utilized were based upon the judgment of the author.

Construction costs are taken from the New Jersey Real Property Appraisal Manual and from the US Bureau of the Census as reported in the statistical Abstract of the US - 1987 (P. 703). The cost used is $\$ 42.25$ per square foot less $\$ .32$ per foot for each unit of density. This reduction reflects the fundamental efficiencies that can be attained from density. The density range utilized (up to 15 units per acre) is sufficiently narrow that there is no chance for cost to go below a reasonable minimum. 
However, this relationship could not be utilized for high density ranges ( 25 units per acre or more).

The other significant costs are soft costs and what are called financing costs. Soft costs include design, engineering, contingencies, and some return. Financing costs include interest, no matter if it is paid to an institution or to the enterprise. All financing costs are marked up from price (200 basis points) and adjusted for absorption rate and therefore lower density developments will bear higher financing costs per unit than higher density developments.

The absorption assumptions are (1) low density ( 1 unit per acre and less) will absorb very slowly; (2) medium density (4 to 8 units per acre) will have the most rapid rate of absorption; and (3) density between 2 and 4 units per acre and over 9 units per acre will experience medium absorption. The significance of these assumptions is that financing costs are inversely proportional with absorption.

The primary conclusion from the analysis of revenue was that unit price declines with density and that the negative price effect of density may be mitigated with an amenity package. At the lowest density ranges amenity appears negative. The interpretation of this factor is that the large lot constitutes the amenity and thus the builder/developer tends not to provide additional amenities. Alternatively, the cost of the amenity (large lot area) is built into the land and land development costs. As density increases ( 6 units per acre and above) 
developers tend to provide amenities as a package which generally feature recreation. There is a direct cost for the provision of such amenities. A cost of $\$ 12,500$ per unit was incorporated into land development as the cost of providing such amenities. Analysis of these data indicated that generally developers would have to provide some amenity package in order for more dense forms of development to be profitable. These data also imply that more dense forms of development without amenities would have to provide very small units and would have to acquire land at relatively low prices. This analysis excludes such consideration.

These cost parameters were used in conjunction with estimated revenues to arrive at an analysis of incremental profit with increased density. Both revenues and costs are highly aggregated and are stretched over the entire study area. This is done with the knowledge that no single expression can capture all of the nuances of the regional market. However, the relative values, rather than the absolute values, should be generalizable to the entire region.

The incremental analysis looked to the additional profit that would be earned at alternative densities of development. These incremental values were expressed both in terms of acres and individual units. The increments analyzed began with 5 , acre tracts (a density of 0.20 units per acre) and went to 10 units per acre, in increments of 1 unit. The results were discounted by $50 \%$ to arrive at an estimate of the land residual. The relative values are:

Appendix D Page 14 
INCREMENTAL LAND VALUE PER ACRE

PERCENT OF HIGHEST

FROM :

\begin{tabular}{|c|c|c|c|c|c|c|c|c|c|c|c|}
\hline $\begin{array}{l}\text { TO: } \\
.25 \\
.33 \\
.50 \\
1 \\
2 \\
3 \\
4 \\
5 \\
6 \\
7 \\
8 \\
9 \\
10\end{array}$ & $\begin{array}{r}0.20 \\
6.68 \\
9.28 \\
10.88 \\
21.58 \\
36.88 \\
53.98 \\
67.78 \\
72.28 \\
78.68 \\
87.48 \\
98.48 \\
100.08 \\
89.58\end{array}$ & $\begin{array}{r}2.68 \\
4.28 \\
15.08 \\
30.28 \\
47.48 \\
61.28 \\
65.68 \\
72.18 \\
80.88 \\
91.98 \\
93.48 \\
83.08\end{array}$ & $\begin{array}{r}1.68 \\
12.38 \\
27.68 \\
44.78 \\
58.58 \\
63.08 \\
69.48 \\
78.28 \\
89.38 \\
90.88 \\
80.38\end{array}$ & $\begin{array}{l}10.88 \\
26.08 \\
43.18 \\
56.98 \\
61.48 \\
67.98 \\
76.68 \\
87.78 \\
89.28 \\
78.78\end{array}$ & $\begin{array}{l}15.28 \\
16.18 \\
32.48 \\
33.18 \\
46.28 \\
46.98 \\
50.78 \\
51.48 \\
57.18\end{array}$ & $\begin{array}{l}17.28 \\
31.08 \\
35.48 \\
41.98 \\
50.68 \\
61.78 \\
63.28 \\
52.88\end{array}$ & $\begin{array}{l}13.88 \\
18.38 \\
24.78 \\
33.58 \\
44.58 \\
46.18 \\
35.68\end{array}$ & $\begin{array}{r}4.58 \\
10.98 \\
19.78 \\
30.78 \\
32.38 \\
21.88\end{array}$ & $\begin{array}{r}6.48 \\
15.2 \% \\
26.3 \% \\
27.8 \% \\
17.3 \%\end{array}$ & $\begin{array}{r}8.8 \% \\
19.8 \% \\
21.4 \% \\
10.9 \%\end{array}$ & $\begin{array}{r}11.1 \% \\
12.6 \% \\
2.1 \%\end{array}$ \\
\hline
\end{tabular}

This first matrix shows the increase in land value (land residual) from increasing density as a percentage of the highest increase. Thus, increasing density from 0.20 to 0.24 will increase (residual) land value per acre by $6.6 \%$ of the highest. Going from 0.20 to 1 would increase by $21.5 \%$, and so forth. The highest increment would be for increasing from 0.20 to 9 units per acre thus it is the base for all of the calculations. These data show that the highest land residual increments would accrue from going from the lowest densities to the highest densities. The percentages decrease as the base density increases. However, up to 9 units per acre, there is a positive market inducement to increase densities.

The following matrix shows land residual increment per unit built. As with the above, these are expressed in terms of the highest incremental increase. The highest per unit increment, and thus the base for the table, results by going from 0.20 to 0.25 
units per acre. However, there is a positive increment in most of the density ranges. As with the per acre calculations, the relative increment decreases as the base density increases.

\section{INCREMENTAL LAND VALUE PER UNIT PERCENT OF HIGHEST}

\section{FROM :}

TO: $\quad 0.20$

.25100 .08

$.3352 .6824 .1 \%$

$.5027 .48 \quad 12.98$

215.68

314.78

413.68

13.28

13.18

12.48

16.48

$12.68 \quad 13.28$

$12.8 \%$

12.28

13.28

11.68

$12.48 \quad 13.18$

$12.48 \quad 11.78$

$11.8 \%$

10.58

10.3810 .48

9.78

9.08

7.08

9.68

9.48

9.48

8.78

8.08

6.38

6.48

3.48

9.88

8.98

8.48

7.78

8.98

$8.48 \quad 7.88$

6.88

4.28

4.98

6.98

5.98

5.98

6.78

6.78

$8.7 \%$

8.18

8.08

$8.0 \%$

$7.5 \%$

5.08

4.98

5.38

$7.6 \%$

3.98

$2.8 \%$

$2.6 \%$

$5.4 \%$

2.18

$8.4 \%$

$4.8 \%$

0.58

The relative values have been shown because they should have some validity in most of the area of the Pinelands. The absolute values are set out below. Great care should be exercised in the use of the absolute values. These figures are averages over the entirety of the area. As such, they attempt to depict the average or typical situation. They should not be used to predict or project actual values in individual developments, areas, or situations. 
INCREMENTAL LAND VALUE PER ACRE AT $50 \%$

FROM :

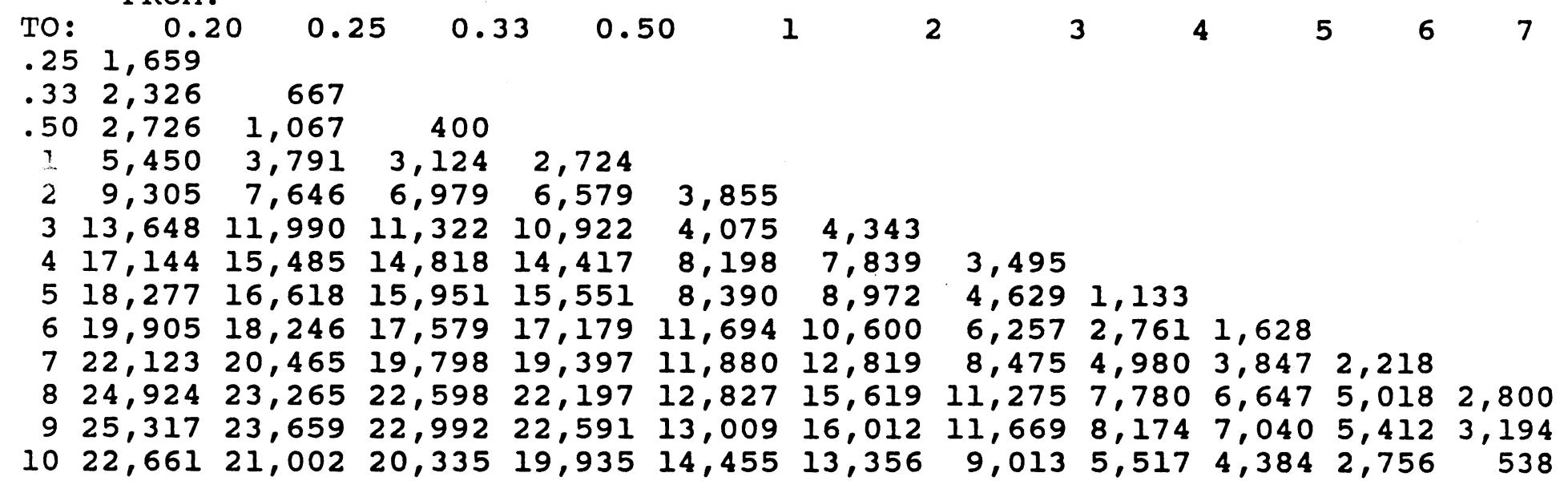

The average incremental value per acre for increasing from 0.20 to 0.25 is $\$ 1,695$. However, the average incremental value perr unit is $\$ 33,176$. The value per unit tends to be very high but the value per acre is low because of the low density. Note might be taken of the fact that this analysis showed that lowest density would tend to be unprofitable and the incremental profits reflect a lower loss. The primary reason for these losses is that the cost of land plus improvements is too high relative to the market prices which can be attained. These data should not be interpreted as meaning that lowest density development ( 2 acre lots and larger) is not economic. Rather, such forms of development will tend to occur in low land cost areas and in areas characterized by locally high housing prices. Additionally, any such developments will also tend to provide only minimal land improvements. The proper interpretation of these facts is that lowest density development has very limited market potential. This is the reason 
why the highest increments are to be found in moving from the lowest base density.

INCREMENTAL VALUE OF UNIT AT $50 \%$

FROM :

\begin{tabular}{|c|c|c|c|c|c|c|c|c|c|c|c|}
\hline $\begin{array}{l}\text { TO: } \\
.25 \\
.33 \\
.50 \\
1 \\
2 \\
3 \\
4 \\
5 \\
6 \\
7 \\
8 \\
9 \\
10\end{array}$ & $\begin{array}{l}0.20 \\
33,176 \\
17,444 \\
9,088 \\
6,812 \\
5,169 \\
4,874 \\
4,512 \\
3,808 \\
3,432 \\
3,253 \\
3,195 \\
2,877 \\
2,312\end{array}$ & $\begin{array}{l}8,005 \\
4,270 \\
5,055 \\
4,369 \\
4,360 \\
4,129 \\
3,499 \\
3,173 \\
3,032 \\
3,002 \\
2,704 \\
2,154\end{array}$ & $\begin{array}{l}2,403 \\
4,686 \\
4,187 \\
4,246 \\
4,041 \\
3,418 \\
3,102 \\
2,970 \\
2,948 \\
2,653 \\
2,104\end{array}$ & $\begin{array}{l}5,447 \\
4,386 \\
4,369 \\
4,119 \\
3,456 \\
3,123 \\
2,984 \\
2,960 \\
2,658 \\
2,098\end{array}$ & $\begin{array}{l}3,855 \\
4,099 \\
3,898 \\
3,207 \\
2,891 \\
2,779 \\
2,782 \\
2,483 \\
1,912\end{array}$ & $\begin{array}{l}4,343 \\
3,919 \\
2,991 \\
2,650 \\
2,564 \\
2,603 \\
2,287 \\
1,670\end{array}$ & $\begin{array}{l}3,495 \\
2,314 \\
2,086 \\
2,119 \\
2,255 \\
1,945 \\
1,288\end{array}$ & $\begin{array}{r}1,133 \\
1,381 \\
1,660 \\
1,945 \\
1,635 \\
920\end{array}$ & $\begin{array}{r}1,628 \\
1,923 \\
2,216 \\
1,760 \\
877\end{array}$ & $\begin{array}{r}2,218 \\
2,509 \\
1,804 \\
689\end{array}$ & $\begin{array}{r}2,800 \\
1,597 \\
179\end{array}$ \\
\hline
\end{tabular}

A matter of interest is the potential use of PDCs based upon the size of the dwelling either sperate from or in conjunction with density. A regression equation was estimated using this data series with unit size, in square feet, as the primary determinate of sale price. This analysis yielded poor results. Such poor results may be due to a lack of appropriate data or to a fundamental failing of the proposition. However, this analysis would indicate little potential for a program based upon unit size. In any future analysis, this proposition may be directly tested and perhaps a different conclusion may be reached. 


\section{CONCLUSIONS}

The objective of this study was to obtain insight into the potential use of Pinelands Development Credits. Another way of posing this question is to ask which density increases yield the highest incremental profits.

of necessity, this analysis must generalize over a very large area. Due to expected sub-regional variations, only the relative values (percentages) should be accepted as having region-wide relevance. Even the relative values will lack applicability in individual situations. Nevertheless, certain conclusions may be drawn from this analysis.

A. There is limited market potential for lowest density ( acre and larger lots) density except in isolated situations characterized by very low land-costs and/or very high housing prices.

B. There is limited market potential for higher density ( 6 units per acre and higher) forms of development unless the development is configured as a Planned Unit Development and provided with amenities. Higher density developments outside of PUDs and without amenities will tend to occur in areas of low land prices and will tend to be characterized by very small units sizes.

c. Highest incremental values will occur with the lowest densities. This is due to the fact that lowest density forms of development have limited market potential.

D. Positive incremental values continue to be observed up to the 9 to 10 unit per acre range. Even though developments with densities higher than these can be observed in the region, this analysis indicates that such developments would receive, at best, marginal economic value from the use of PDCs.

E. PDCs would tend to have their highest values in the lower density ranges. However, PDCs would continue to have value up to the 9 to 10 units per acre range. such value in the latter ranges would tend to be limited to larger tracts that had sufficient space for the amenities which appear to be required in the market area.

$$
\text { Appendix D Page } 19
$$


F. The high incremental values of additional units in lowest density zones would not require large sites. Rather, additional units could be added on an incremental basis on relatively small sites with a significant improvement in return.

This analysis indicates that the PDC program should enjoy some degree of market acceptance. As the program is currently structured, this acceptance would tend to be found in larger developments of the PUD type. This analysis indicates that the PDC program could also find market acceptance in the lower density (and smaller sites) ranges. 


\section{APPENDIX}

The analysis utilizes the economic concepts of average and marginal revenue products. The average revenue product is the net return per unit. The marginal revenue product is the return that would be received by adding one additional unit. The body of this report dealt with the incremental value of changing a 50 acres parcel of land from lower to higher density. While specified differently, it is still the basic concept of average and marginal products. The following figure shows the average and marginal revenue products that resulted from this study. As with the analysis presented above, great care must be exercised in attempting to apply these data to any specific development. With this caution in mind, it is interesting to look at the graphic.

This graphic shows the density ranges that tend to be profitable. It also shows how profitability changes with density. As pointed out in the text, development in the density ranges of 1 to 9 units per acre tends to be the most economic. Again, this is not to say that lower or higher densities are not economic. Rather, looking at the Pinelands as a regional market, development within these ranges would appear to be the better alternatives. It is significant to note that the marginal remains positive as density increases. In fact, it is almost flat. 


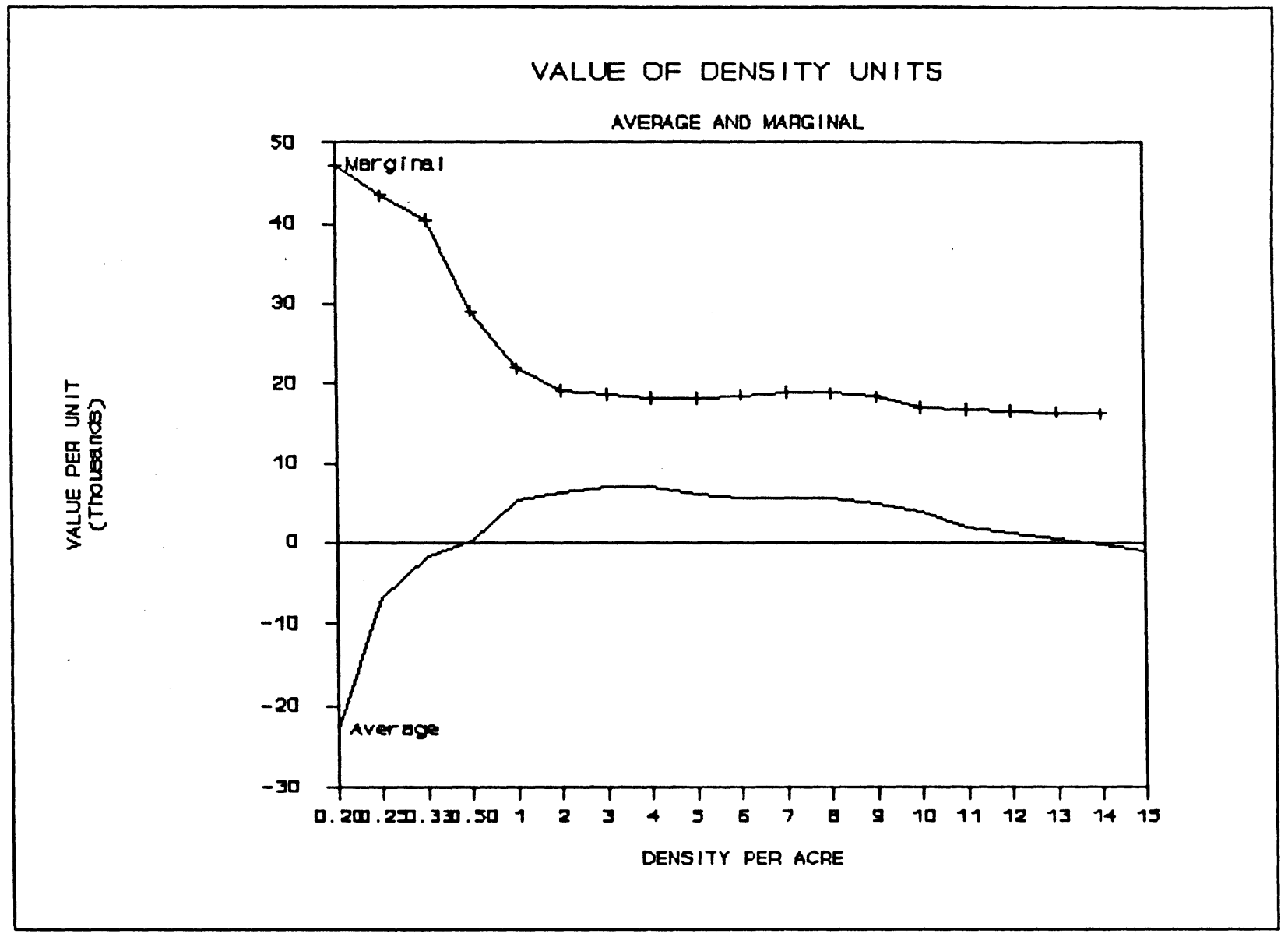

Appendix D Page 22 
APPENDIX E.

Policy and Program Alternatives 


\section{APPENDIX E \\ PINELANDS DEVELOPMENT CREDIT PROGRAM POLICY AND PROGRAM ALTERNATIVES}

In the course of this study, a number of possible actions to further improve the operation of the PDC were identified. Some 34 different options were grouped into one of two broad categories -- those which might serve to stimulate greater demand for the use of Pinelands Development Credits and those which might improve the supply of PDCs available for use. Within each of these broad categories, options were further grouped according to subject.

I. Stimulating Demand For PDC Use

A. Density in Regional Growth Areas

1. Lower base and maximum densities.

In order to lower the densities at which PDC use is triggered, the average base densities in RGAs could be lowered. Retaining the current CMP requirement that average base densities must be increased by 508 for PDC use, the maximum densities in RGAs would be similarly reduced.

\section{Advantages :}

Base densities as well as the threshold densities for PDC use would be lowered in some areas, making development without using PDCs less likely.

Overall development required in certain areas would be lowered, possibly reducing municipal resistance to the program.

\section{Disadvantages:}

Overall development potential for RGAs would be lowered.

Since the number of PDC redemption opportunities would decrease, the ratio of redemption opportunities to PDC allocations would be eroded. 
A municipality, in the conformance process, could still seek to concentrate PDC opportunities in higher density ranges, and/or build in loopholes like "adult community" options.

2. Lower base densities but retain the current maximum densities permitted with the use of PDCs.

Although average base densities in Regional Growth Areas would be reduced, maximum densities would not change. This would effectively reduce the threshold for PDC use without affecting the maximum development potential of RGAs.

\section{Advantages :}

Would lower base densities as well as the threshold densities for PDC use, making less development possible without using PDCs.

Would increase the total number of PDC redemption opportunities.

Would increase the ratio of PDC redemption opportunities to allocations.

Would preserve the current maximum RGA development potential.

\section{Disadvantages:}

Would not prevent overly high base densities in some zones.

May leave many PDC opportunities concentrated in higher density ranges.

Would not reduce the maximum possible development in municipalities where the amount of potential development is a point of contention.

3. Establish a density above which PDC use is limited or prohibited.

For purposes of establishing zone capacities and the ratio of PDC to non-PDC use, the current base densities and required PDC development increment would remain unchanged. However, as municipalities establish individual zoning district regulations, they. would be required to provide all or a substantial portion of PDC redemption opportunities below a certain density. That density would be established such that PDC use is largely afforded at single family, detached density ranges. 


\section{Advantages:}

Would reduce the number of PDC opportunities which exist in higher density ranges and increase opportunities in lower density ranges.

Would maintain the existing total number of PDC redemption opportunities and the existing ratio of PDC redemption opportunities to PDC allocations.

Would allow for municipal incentive zoning schemes to permit adult housing, planned unit development, affordable housing, and so on, without placing added cost burden on every added unit.

Municipal flexibility in establishing maximum zone densities would be retained

\section{Disadvantages:}

Municipal flexibility in establishing density ranges where PDC use is permitted would be diminished.

Although maximum development potential would be retained, PDC use would in some cases be required before non-PDC units would be permitted.

By adding to the cost burden of lower density housing, development could be discouraged in RGAs.

4. Establish a threshold above which PDC use would be required.

This approach is similar to the above option except that municipalities would be permitted to allocate PDC redemption opportunities in higher density zones as long as the threshold density which triggers their use is kept relatively low.

\section{Advantages:}

Individual zones allowing for higher density development without any PDC use would be eliminated.

Would maintain the existing total number of PDC redemption opportunities and the existing ratio of redemption opportunities to PDC allocations.

Municipal flexibility in establishing maximum zone capacities would be retained. 


\section{Disadvantages:}

Would still permit a disproportionate share of PDC redemption opportunities to be allocated at higher densities.

Municipal incentive zoning schemes involving higher densities for adult housing, planned development, and affordable housing would involve substantial PDC use.

Municipal flexibility in establishing the density ranges when PDC use is permitted would be eliminated.

5. Guarantee that a proportion of all residential development in RGAs utilize PDCs.

This option would work independently of PDC density thresholds and require that a certain percentage of all residential lots created or units developed redeem PDCs. The development capacities now required in the CMP could be reduced since PDC use is guaranteed and an exemption for small projects could be afforded.

\section{Advantages:}

Virtually all residential development would involve PDC use.

PDC use would not be dependent upon the density of residential development.

\section{Disadvantages:}

Mandatory nature could generate resistance to change.

If PDC owners were not willing to sell, RGA development would be halted.

The demand for PDCs might outstrip the supply. Alternatively, the price for PDCs might increase to a level that would discourage development in RGAs.

This would place a greater cost burden on residential development in RGAs. It would particularly place a greater cost burden on higher density/lower cost housing, and might make construction of more affordable housing unfeasible. 
6. Require PDC use for all development in RGAs on a per acre basis.

The purchase of some number of PDCs per acre of land developed could be required, regardless of the density of the development.

It would probably be best for a number of reasons for the number of PDCs required to be relatively low. Waiver of the requirement for construction of a single house on a lot owned as of the effective date of the new regulation could be considered in order to avoid placing a burden on owners of small lots.

\section{Advantages:}

The use of PDCs would be assured.

The PDC requirement would act, economically, like an increase in the cost of land. This would tend to favor slightly more intense development rather than very low density development.

The cost burden per unit would decrease as the number of units per acre increased. This would therefore not seriously burden the cost of constructing more affordable housing.

Municipal zoning could be simplified, because there would be no need to have base and PDC densities with related development standards.

\section{Disadvantages:}

Mandatory nature could generate resistance to change.

If PDC owners were not willing to sell, RGA development would be halted.

The demand for PDCs might outstrip the supply. Alternatively, the price for PDCs might increase to a level that would discourage development in RGAs .

It represents a significant change in the structure of the PDC program and could create confusion. 
7. Establish a net density threshold for PDC use which is independent of gross densities.

Due to development constraints such as wetlands, certain properties may be developed at relatively high net densities although gross densities are not high. Establishment of a net density threshold would require PDC use for properties which benefit substantially from "clustering" provisions.

\section{Advantages:}

Expands PDC use opportunities.

Couples PDC use with clustering provisions which reduce development costs and permit more efficient development patterns.

\section{Disadvantages:}

Makes the program more difficult to understand.

Overall impact on PDC use opportunities may not be great.

8. Re-examine municipal ordinances to: determine if conditional use and incentive zoning (e.g. adult housing and planned development) options which involve higher densities actually result in development capacities that exceed CMP requirements; require that a greater proportion of PDC redemption opportunities be provided in lower density zones; and ensure that density schemes are realistic considering detailed analysis of land tenure patterns and environmental constraints.

Without any changes to the basic structure of the PDC program, each municipal ordinance can be modified to improve the operation of the PDC program. In addition, detailed analyses of conditional use programs which permit higher density development would yield a more realistic estimate of their effect on development capacities than was done at the outset of the conformance process.

\section{Advantages:}

Retains the current structure of the CMP's density and PDC program.

Improved operation of the PDC program and the potential for PDC use can be tailored to individual municipalities. 


\section{Disadvantages:}

Commission might be forced to decertify municipalities if they are unwilling to make changes resulting from the analysis.

Municipalities may resist zoning changes on the basis of prior Commission approval of their ordinances.

9. Clarify PDC use requirements when maximum densities are exceeded.

Two provisions of the CMP (N.J.A.C. 7:505.28(a) $3 i \mathrm{i}$ and N.J.A.C. $7: 50-5.28(\mathrm{a}) 4$ ) have been interpreted by some in a contradictory manner such that PDCs may not be needed if a municipal variance is granted which permits development at densities higher than that specified by ordinance. When revised in 1987 , the CMP was amended to require PDC use when densities are increased by virtue of a municipal variance. By eliminating contradictory language in N.J.A.C. 7:50$5.28(a) 3 i i$, the intent of the 1987 CMP amendment = can be made clear.

\section{Advantages:}

Municipalities are afforded the latitude to grant density related variances.

PDC use would clearly be needed when variances which have the affect of increasing development potential are granted.

\section{Disadvantages:}

Individual property owners would be required to redeem PDCs if they receive a variance to permit development on an undersized lot.

\section{B. Development Standards Which Impact Utility of the Land}

1. Eliminate or modify wetlands buffer requirements to free-up additional land for development.

The establishment of buffers constrains many sites, and reduces the overall unit yield available to the developer, or requires the building of a different and less valuable unit type such as townhouses instead of single family detached dwellings. 
Buffer standards in Regional Growth Areas could be reduced significantly except for instances where a wetland is shown to be of extraordinary importance. Instead of buffers of 100 to 300 feet being routine, RGA buffers might routinely be 25 to 100 feet. The amount of additional land that could be developed would be extensive, and the number of developments that would become eligible for PDC use would increase.

\section{Advantages:}

More land would be available for development. This would either result in lower net densities or permit gross densities and the use of PDCs to increase.

\section{Disadvantages:}

A lower degree of protection of Pinelands environmental resources would be achieved.

The Commission's credibility could be damaged because it would appear that environmental protection is negotiable in pursuit of other ends.

2. Relax on-site water quality standards for development without sewers.

Densities which permit PDC use generally require the presence of sewer. Some otherwise prime areas for development have no sewer available and are not likely to have sewers constructed in the near future. If water quality standards were relaxed, while still protecting human health, additional areas could be made practical for PDC development without the installation of sewers.

\section{Advantages:}

Additional development opportunities that could use PDCs would be made practical without the delay and expense of sewer construction.

Environmental issues arising from interbasin transfer of water would be avoided.

\section{Disadvantages:}

The same disadvantages as the previous option. 
3. Speed up the approval and construction of the Pinelands Infrastructure Trust sewer projects.

The need for viable development opportunities in the receiving area is an acknowledged condition for the success-of any TDR program. The Pinelands Infrastructure Trust was created in part to address the need for sewers in key Regional Growth Areas. If all of the project selected for funding were completed, the operation of the PDC program would most likely be greatly enhanced. Progress of PIT projects has been slow. A majority of applicants have not completed submissions to DEP. of those that have submitted material to DEP, only one has completed the review process and is eligible to receive funding, and that one may not receive funds until the county where it is located achieves conformance.

\section{Advantages:}

Completion of these sewer projects would directly address one of the major constraints to development in RGAs. This is important both to the PDC. program and to the implementation of the CMP for RGAs.

Where projects are planned that will eventually use PDCs, the projects are unlikely to proceed to final municipal approval and construction until sewer service is actually available. Until that time, PDC use is only potential, even for projects with preliminary municipal approval. Provision of sewer service should enable these projects to actually be constructed.

Several projects have been proposed at low densities, suitable for development on septic systems, even though zoning would allow considerably higher density if sewers were available. Some of these projects might be reoriented to use higher densities and PDCs if it were apparent that sewer service were eminent. Provision of sewer service would favor PDC use, and would prevent prime development sites from being pre-empted by premature low density development.

\section{Disadvantages:}

Commission has little direct influence in the approval process and could expend significant staff resources without much success. 
C. Modification of Receiving Areas

1. Expand the size of RGAs.

Area which is now RDA or Forest could be changed by CMP amendment to RGA.

\section{Advantages:}

Additional PDC redemption opportunities would be created, and the ratio of redemption opportunities to allocations would be increased.

\section{Disadvantages:}

Merely expanding the size of RGAs would not address other areas of the PDC program which could be improved.

Expansion would compromise the environmental protection goals of the CMP.

2. Reguire that Municipal Reserves, when triggered for RGA development intensities, permit develop-ment at densities above 1 dwelling unit per acre with PDCs.

Municipal Reserves are portions of Rural Development Areas which can be rezoned at higher densities when adjoining Regional Growth Areas are fully developed. This option would retain the basic structure of the Municipal Reserve program but require that a low threshold for PDC use be established.

\section{Advantages:}

Greater PDC use opportunities are afforded when municipal reserves are rezoned at higher densities.

Minimizes disruption in current municipal zoning schemes.

\section{Disadvantages:}

Since the number and extent of municipal reserves are limited, the number of additional PDC redemption opportunities will be limited.

This will not result in any immediate benefits since municipal reserves represent a longer term growth management tool. 
Advantages :

Would increase the number of PDC redemption opportunities and increase the ratio of redemption opportunities to allocations.

Because Towns are similar in many respects to RGAs, this option would treat them more similarly than the CMP now treats them.

\section{Disadvantages:}

As with the option of simply increasing the amount of RGA land, this option would do nothing to address whatever other improvements in the program are felt to be necessary.

Would require the Commission to establish density standards and disrupt currently certified municipal zoning schemes.

4. Use PDCs in Rural Development Areas

\section{Advantages:}

This would be consistent with the conclusion that a bonus unit is worth the most at relatively low density. The apparently high economic value of the PDC bonus unit in the low density setting suggests that the option might be effective at stimulating more PDC use.

\section{Disadvantages:}

More development would be encouraged in areas where it has already been determined that the amount of development should be limited.

Might serve to attract development away from RGAs.

5. Use PDCs in Forest Areas.

(Same advantages and disadvantages as RDAs)

6. Require PDC program to be implemented in the Pinelands National Reserve.

\section{Advantages:}

Additional PDC redemption opportunities would be created. 
The housing market may be more mature, and development areas may already have infrastructure in place to serve them.

\section{Disadvantages:}

This would require legislation to implement.

\section{Ordinance Development Standards}

1. Re-examine municipal ordinances and eliminate bulk standards which effectively reduce density.

Some ordinances may couple densities with minimum lot sizes, setback requirements and other development standards that make it impossible for the permitted densities to be achieved. This option would require that standards be revised so that stated densities can actually be achieved.

\section{Advantages:}

Barriers to the achievement of PDC densities would be removed.

\section{Disadvantages:}

Resistance to more flexible bulk standards might occur.

2. Eliminate confusion regarding PDC density and development provisions.

PDC density and associated development standards are often not included in the area and bulk regulations applicable to individual zoning districts. The action contemplated here would serve to better organize ordinances so that PDC density and associated development standards are, in fact, presented in a clear and uniform manner.

\section{Advantages:}

PDC use opportunities would be included in individual zoning district regulations and would be clearly set forth as a matter of right and not negotiation.

\section{Disadvantages:}

Some municipalities might resist formatting changes to their ordinances. 


\section{E. Expanding PDC Use Opportunities}

1. Permit Municipal substitution of PDC for commercial and industrial uses for part of their residential PDC zoning requirement.

At present, municipalities must zone to permit at least a specified base number of units. In addition, $50 \%$ more units must be zoned for contingent upon the purchase of PDCs for the added units. At the municipality's option through the conformance process, the $50 \%$ increment could be offset in whole or in part by building PDC use into commercial and industrial zoning if:

a) the municipality requests the use of the option, or

b) the Pinelands Commission finds that current PDC opportunities are in higher density ranges and are thus less likely to be used.

The PDC use opportunities which remain in residential zones would have to meet the CMP standards for single family detached residential use.

PDC use for commercial and industrial would be based upon:

a) A minimum square footage threshold that permits neighborhood commercial uses to be built without PDCs.

b) Minimum square footage threshold which permits local industrial uses to be built without PDCs.

c) PDCs would be required for additional square footage in accordance with a to-be-developed formula that establishes a rough equivalence of PDC value to PDC value when used in a residential setting. Total square footage, rather than Floor Area Ratio (FAR), appears to be useful, because larger commercial facilities frequently have lower FARs than smaller ones.

When a use variance is granted to permit nonresidential use in a residential zone, approval would be conditioned upon purchase of PDCs in accordance with the above formula. 


\section{Advantages:}

CMP base residential requirements would be met, yet municipalities are given latitude to adjust maximum development capacities if they believe the PDC increment results in overdevelopment.

Avoids instances where a disproportionate share of PDC use opportunities is afforded in higher density residential development.

Permits municipalities more flexibility in developing zoning schemes for commercial and industrial uses while not sacrificing development character in residential areas.

Should result in lower PDC residential thresholds in communities where the option is exercised.

\section{Disadvantages:}

Makes the PDC program more complicated to understand.

Increases the complexity and burden on staff and local officials in developing zoning plans.

Implementation delays will be caused while a sound formula is being developed.

PDC price projection becomes more difficult.

2. Permit PDC Use For Commercial and Industrial

Development.

This is similar to the above option except that municipalities would be required to zone for PDC use in commercial and industrial development. As such, current residential zoning would remain unchanged and commercial and industrial zoning would increase the total number of PDC redemption opportunities.

\section{Advantages:}

Would increase the total number of PDC redemption opportunities.

Would create PDC redemption opportunities where a great deal of value in land development exists.

Would create a greater degree of parity between residential and non-residential landowners. 
Would have a discouraging effect on commercial and industrial development and may reduce the development of municipal nonresidential tax-ratable base.

Would add complexity to understanding the PDC program.

3. Establish residential floor area threshold for PDC use.

In addition to PDC densities, a maximum floor area for a single dwelling unit would be established for approval without PDC use. For units with larger floor areas, a quarter PDC would be required for each additional increment of floor area. The floor area threshold might be, for example, $1200 \mathrm{sq}$. ft., and the size of the increment might be $500 \mathrm{sq}$. ft. Under that scenario, a house with a floor area of $1600 \mathrm{sq}$. ft. would require purchase of .25 PDC, a house with a floor area of $1800 \mathrm{sq}$. ft. would require purchase of .50 PDC.

\section{Advantages:}

Would engender PDC use for development of large houses at low densities. (This mode of development serves upper income households, but generally does not participate in the current PDC program.)

Would place the greatest burden of PDC purchase on the upper income market which can best afford it, rather than on the lower income market which the current PDC program tends to burden.

Has a good likelihood of successfully causing PDC use. (Based on California experience at San Luis Obispo.)

\section{Disadvantages:}

As an overlay on the existing program, this would add a great deal of complexity.

This would be extremely difficult to administer.

If the threshold were established at a low enough level that a great deal of housing needed PDCs, it would be viewed as a burden on individual home purchasers. If the threshold were established at a much higher level, it would be triggered rarely, and would generate little PDC use. 
According to the economic analysis, residual values for homes don't increase on a par with square footage.

4. Sliding scale which increases the units per PDC for various housing types.

It is known that the value of additional units built as a result of PDC purchase is different for different types of housing. In particular, the value of an added townhouse is generally less than the value of an added single family detached house. The value of an added apartment unit, in turn, is less than the value of an added townhouse. In the program as it stands, a great many PDC redemption opportunities exist in zoning densities that imply the construction of townhouses or apartments. This may make PDC use less likely for purely economic reasons.

To remedy this problem, a sliding scale could be established providing for greater unit bonus returns per PDC for different types of units. For example, a PDC could allow for 4 added single family detached houses, or 6 additional townhouses, or 8 additional apartment units.

\section{Advantages:}

Would increase the economic attractiveness of townhouse and apartment development, consequently making the use of the related PDC opportunities more likely.

Would make the value of a PDC more equal in various development settings.

Would decrease the economic burden placed on higher density-lower cost housing.

\section{Disadvantages:}

Would add to the complexity of the program and make it harder for developers and municipal officials to understand.

If the market for higher density housing remains stable, a number of PDC use opportunities may still go unused.

The ratio of redemption opportunities to PDC allocations would be reduced. 
1. Afford priority review status for PDC projects

Interviews of developers have disclosed that delays in receiving project approvals influence the type and magnitude of projects proposed. PDC use may be more attractive if it is known that review of applications will be efficient and will not involve undue delays. This could simply mean that no added delay in introduced due to the use of PDCs, however, a further measure could be taken and actually expedite the review of a project precisely because it uses PDCs.

\section{Advantages:}

PDC project reviews can be expedited without sacrificing environmental standards.

\section{Disadvantages:}

A perception could be created that PDC projects are not being held to the same standards as other projects.

Commission review of non-PDC projects would be delayed somewhat.

\section{Inform landowners and developers in receiving} areas

A program of promotion and education could be undertaken via printed literature, staff appearances at community and interest group meetings, and meeting with individual landowners and developers. This process could ensure that potential participants fully understand the program, and could provide needed stimulus and encouragement, and build confidence that the review process is able to deal with the appearance of development applications that entail the use of PDCs.

\section{Advantages:}

Interviews conducted on behalf of the PC indicated that many of the key actors in the PDC program had a low awareness level of the PDC program, and even when they were aware of the program, many individuals did not understand the program clearly. on the other hand, developers who had previously used PDCs were fairly positive about the program and indicated that they would probably be inclined to make use of it again. This option would ensure 
that decision making by landowners and developers would be made with accurate information, awareness and a clear understanding of the operation and advantages of the program.

This option could be compatible with either a program that remains unchanged in substance, or a program that is altered in substance.

\section{Disadvantages:}

Without additional staff resources it's unlikely that an aggressive program could be implemented.

A staff person undertaking this role might be viewed as a self-serving propagandist.

3. PDC advocate.

This option would involve the establishment of one or two staff positions to be devoted to promotion of the program. In comparisons of the Montgomery County program and the Pinelands program, it has been noted by several writers that the Montgomery County program may be more successful in part due to the full time attention of two staff members during the early years of the program.

If two positions are created, that which is devoted to educating sending area property owners should be located within the state Pinelands Development Credit Bank. On the other hand, the position which focuses on receiving areas might best be located within the Pinelands Commission.

\section{Advantages:}

The existence and activities of advocacy staff has been identified as an important factor in TDR program success.

The promotion activities described above cannot practically be performed by staff already in place.

As was the case in Montgomery County, this mayonly require a temporary, several year effort.

\section{Disadvantages:}

Would require additional funding for salary, office space, and added support service expense.

A staff person undertaking this role might be viewed as a self-serving propagandist. 
A perception might be created that environmental standards are being relaxed for PDC projects

\section{Ensuring an Adequate Supply of PDCs}

A. Price

1. Guarantee a minimum sale price which is attractive to sellers.

It's assumed a greater number of PDCs will be placed on the market for sale if the sales price increases. A number of the aforementioned options deal with the program's structure so as to strengthen economic value; thus, this option is geared to an absolute "guarantee" established by the government.

In fact, the NJ PDC Bank and the Burlington County PDC Bank purchase PDCs for no less than $\$ 10,000$. They are unable to guarantee that anyone and everyone who may wish to sell will be paid that amount. The minimum price could be increased, and/or the policy could be altered to indicate that anyone wishing to sell would be paid the guaranteed minimum price.

\section{Advantages:}

Owners of PDCs indirectly receive more benefit from their land.

More PDCs might be sold and available for redemption.

Prevents price decline due to too many PDC owners trying to sell simultaneously.

\section{Disadvantages:}

Government price supports may require a large expenditure of funds.

Interferes with the establishment of a free market.

Difficult to establish a price which property owners may consider "fair".

Guarantee could price certain developers out of the market and, if too high, could seriously impair their use in Regional Growth Areas. 
2. Increase the unit yield for PDCs.

Sliding scales aside, the number of bonus units per PDC could be increased from the present 4 bonus units per PDC to something greater, such as 8 bonus units per PDC. This would have the effect of making each PDC more valuable.

\section{Advantages:}

Increasing the value of the PDC should make the transaction more attractive to both buyer and seller and have the effect of increasing the number of PDC transactions.

The approach is straightforward enough that it should be understandable to persons who understand the mechanism of the program as it now exists.

\section{Disadvantages:}

The change in ratio would introduce a problem of handling the transition between the old PDC/bonus unit ratio and the new PDC/bonus unit ratio. While this could presumably be handled by the NJ. PDC Bank through its issuance and re-issuance of PDC certificates, it would no doubt create some confusion.

The change in ratio would reduce or eliminate the excess of PDC redemption opportunities over PDC allocations. If the ratio of allocations to opportunities is currently around $2: 1$, the ratio would become $1: 1$ if one PDC were made to be worth 8 bonus units.

\section{B. Marketing}

1. Promote the PDC program to landowners.

While the progress of the PDC program to date has focused on the question of developers using PDCs for density increases, the supply of PDCs could become a problem quickly if one or two large projects that are now viewed as uncertain should proceed to construction.

One approach to marketing is to prepare informational material that explains the program. To a degree, this has already been done. Additional activities could involve mail and/or individual personal contact to ensure that landowners are aware of the program, and that they understand 
what they can gain and how much or how little they relinquish by recording an easement and selling a PDC.

\section{Advantages:}

Would probably increase the level of support for the program among landowners.

Might increase the supply of PDCs available for sale, with or without other program changes.

\section{Disadvantages:}

To the extent that current resistance is based on substance rather than unfamiliarity, it could be ineffective, at least in the absence of concurrent changes to the actual working of the program.

2. PDC Advocate

Refer to I.F.3 for details.

\section{Residual Use of Property}

1. Maximize the residual uses permitted on the sending property.

To the extent that beneficial uses of property must be foregone due to the deed restriction, the loss of those uses could reduce the willingness of property owners to sell PDCs. The most significant case in point may be the right to carry out resource extraction on land where a valid resource extraction permit exists.

If fewer permitted uses are extinguished by the deed restriction, there would less negative effect of recording the restriction.

\section{Advantages:}

Would make selling of PDCs more rational and therefore should increase the number available for sale.

\section{Disadvantages:}

There is already little difference between the uses that most landowners are entitled to prior to and after the sale of PDCs.

In the case of resource extraction permits, it was a deliberate policy decision of the Commission to increase the PDC entitlement for undisturbed land 
and to reduce the entitlement to zero if the permit is exercised and the land is disturbed. This was intended to provide incentive to landowners to sell PDCs rather than disturb land.

Since one of the major purposes of the PDC program is to achieve more permanent protection of the land, allowing more residual land uses would be in direct conflict with these policy decisions.

\section{PDC Allocation}

1. Increase the number of PDCs allocated to current sending property.

The allocation formula could be changed so that land to which PDCs are now allocated would have more PDCs. For example, the allocation to agricultural upland could be increased from 2 PDCs per 39 acres to 4 PDCs per 39 acres. Other allocations might also increase in the same proportion or some other proportion.

\section{Advantages:}

Would increase the yield of value per acre of sending area land, possibly making some landowners more willing to sell.

Would increase the overall supply of PDCs, which could become important if changes in the receiving areas lead to greatly increased demand for PDCs.

\section{Disadvantages:}

The increased number of PDCs would undercut the $2: 1$ ratio of redemption opportunities to allocations unless significant changes are made to permit more PDCs to be redeemed.

Would not increase the economic attractiveness of the PDC to developers, although it might make PDC development more attractive if more PDCs were available for use.

Would generate confusion during a transition period as existing letters of interpretation would have to be translated from the old allocation formula to the new allocation formula. 
2. Increase the number of PDCs by allocating to Forest Areas.

PDCs might be allocated to Forest Area land, or perhaps to that Forest Area land which has been municipally zoned for the largest lots, such as areas where the minimum lot is 40 acres or more.

\section{Advantages:}

Might make additional PDCs available and relieve a potential shortage of PDCs that could develop if current PDC holders are unwilling to sell.

PDC sale and deed restriction would provide protection of Forest Area land and prevent residential construction that is currently allowed. In contrast to current Agricultural Production Area and Preservation Area provisions, the PDC sale would result in a greater degree of restriction than is provided by regulation.

Would provide a greater sense of fairness to those owners of Forest Area land that is currently most restricted.

\section{Disadvantages:}

Increase in the number of PDC allocations would reduce the 2:1 redemption opportunity to allocation ratio unless significant changes are made to permit more PDCs to be redeemed.

Would do nothing to increase the attractiveness of PDC use to developers, although it might make PDC development more attractive if more PDCs were available for use.

3. Simplify and standardize the PDC allocation and adjustment formula.

The current program requires a fair amount of mental arithmetic to translate from acres to PDCs and from PDCs to bonus units. With virtually no change in the actual operation of the program, everything could be made simpler to understand if, for example, 2 PDCs per 39 acres was changed to 1 PDC per 5 acres, and 1 PDC yielded 1 bonus unit.

In a somewhat related vein, there is a provision dealing with the allocation of PDCs when a home is already located on the property or when the right to build a house in the future is retained. At present this provision indicates that the amount 
of land required for the building lot shall be deducted from the parcel before the PDC allocation is calculated. Since lot area requirements vary, the calculation becomes extremely complicated. This could be changed so that the number of PDCs allocated is decreased by .25 PDC (or 1 PDC if the PDC Bonus unit ratio were changed to $1: 1$ ) for each existing home and for each retained right to build a house.

\section{Advantages:}

Simplification and clarification should make the program easier to deal with, and this might reduce psychological barriers to participation.

\section{Disadvantages:}

While the end result would be simple, the transition could create confusion.

Some PDCs would be kept off of the market because landowners would elect to retain the right to build a house. 